$$
\frac{\text { E S T U D I O S }}{\text { FILOSOFIA • HISTORIA - LETRAS }}
$$


CITAM Derechos Reservados.

La reproducción total o parcial de este artículo se podrá hacer si el ITAM otorga la autorización previamente por escrito. 


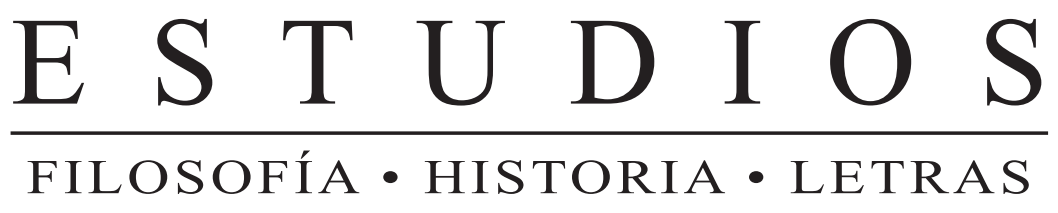

$$
120
$$

PRIMAVERA 2017 
ESTUDIOS • filosofía $\bullet$ historia $\bullet$ letras recoge artículos de investigación, notas académicas y reseñas críticas en torno a las humanidades. Aparece trimestralmente en primavera, verano, otoño e invierno. ESTUDIOS está incluida en los siguientes índices:

- Latindex: Sistema Regional de Información en Línea para Revistas Científicas de América Latina, el Caribe, España y Portugal.

- EBSCO.

- in4mex.

Precio por número: \$ 50.00 M.N. Extranjero 10 dls. (incluye gastos de envío) Suscripción anual (4 números): \$ 180.00 M.N. en la República Mexicana 35 dls. en el extranjero (incluye gastos de envío)

Suscripción bianual (8 números): \$ 350.00 M.N. en la República Mexicana 65 dls. en el extranjero (incluye gastos de envío)

\section{Correspondencia:}

Instituto Tecnológico Autónomo de México

Departamento Académico de Estudios Generales

Río Hondo No. 1,

Col. Progreso Tizapán

01080, Ciudad de México

Tel.: 56284000 exts. 3900 y 3903

correo electrónico: estudios@itam.mx

www.estudios.itam.mx

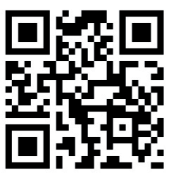

ISSN 0185-6383

Licitud de título No. 9999

Licitud de contenido No. 6993

Derechos de autor: 003161/96

Se agradece el apoyo de la Asociación Mexicana de Cultura, A.C.

Corrección de estilo: Javier Dávila

Diseño de la portada: Nohemí Sánchez

Diseño editorial: Yanet Viridiana Morales García (ITAM)

Distribución: Carmen Graciela Roldán (ITAM)

Impresión y encuadernación: Alfonso Sandoval Mazariego, Tizapán 172, Col. Metropolitana 3a. sección, C.P. 57750, Ciudad Nezahualcóyotl, Estado de México, Tel.: (+5255) 5793 4152/5793 7224 .

Se prohíbe su reproducción total o parcial por cualquier medio, incluido electrónico, sin permiso previo y por escrito de los editores. 


\section{ÍNDICE}

\section{TEXTOS}

FIGURAS DE LA DISTANCIA EN LA TRADUCTOLOGÍA DE WALTER BENJAMIN

Gabriel Astey

EL CONCEPTO DE "OPINIÓN PÚBLICA"

EN MÉXICO (1820-1828)

Gerson Moreno Reséndiz

DE LOS PELIGROS DE LA CREDULIDAD ACRÍTICA María Teresa López Fernández

\section{SECCIÓN ESPECIAL}

LAS RELACIONES DEL CRISTIANISMO

Y EL GOBIERNO IMPERIAL ROMANO

Roberto Jaramillo Escutia

\section{DIÁLOGO DE POETAS}

Javier Márquez Álvaro

\section{CREACIÓN}

Max Román 
ANÁLISIS LITERARIO-ÉTICO DE UN CUENTO DE IGNACIO PADILLA Cecilia Galaviz Álvarez

A PROPÓSITO DE LOS ANTECEDENTES DEL PENSAMIENTO POLÍTICO CUBANO Óscar Puig Corral

\section{RESEÑAS}

ZYGMUNT BAUMAN Y CARLO BORDONI, Estado de crisis, Jaime Ruiz de Santiago

SLAVOJ ZIZEK, La nueva lucha de clases. Los refugiados y el terror, José Manuel Orozco Garibay

JosÉ MANUEL OROZCO GARIBAY,

Nietzsche y la tragedia, Rosario Sarmiento 


\section{FIGURAS DE LA}

DISTANCIA EN LA

TRADUCTOLOGÍA DE

WALTER BENJAMIN

Gabriel Astey*

RESUMEN: Utilizando como principio explicativo la noción de distancia fenomenológica, en el ensayo se exponen las formas de relación entre lengua fuente y lengua meta, y entre texto fuente y texto meta, en la teoría de la traducción de Walter Benjamin.

sose

IMAGES OF DISTANCE IN WALTER BENJAMIN'S TRANSLATOLOGY

ABSTRACT: Using the notion of phenomenological distance as an explanatory principle, we will explore in this article the relationship between source language and target language and between source text and target text in Walter Benjamin's translation theory.

PALABRAS ClAVE: Distancia fenomenológica, traducción ecográfica, traducibilidad, criticabilidad. KEY WORDS: Phenomenological distance, sonic translation, translatability, criticality.

RECEPCIÓN: 4 de agosto de 2016.

APROBACIÓN: 19 de octubre de 2016.

* Departamento Académico de Lenguas, ITAM. 
CITAM Derechos Reservados.

La reproducción total o parcial de este artículo se podrá hacer si el ITAM otorga la autorización previamente por escrito. 


\section{FIGURAS DE LA DISTANCIA EN LA TRADUCTOLOGÍA DE WALTER BENJAMIN}

1. La médula de las reflexiones benjaminianas sobre la traducción literaria se presenta en el breve ensayo que el autor antepuso en 1923 a sus versiones al alemán de los Tableaux parisiens de Baudelaire: Die Aufgabe des Übersetzers ("La tarea del traductor"). ${ }^{1} \mathrm{El}$ texto es célebre tanto por el hermetismo y la densidad conceptual de la prosa del autor, como por la intransigencia con que Benjamin le niega cualquier aspiración comunicativa ${ }^{2}$ a la labor de traducir: tras el aserto de que "ningún poema está destinado al lector", 3

${ }^{1}$ Walter Benjamin, Gesammelte Schriften IV.1 (Herausgegeben von Tillman Rexroth), 1972, Fráncfort del Meno, Suhrkamp, pp. 9-21. Cito siempre esta edición y en todos los casos soy responsable de la traducción de los pasajes, pero he tenido a la vista la versión al español de H. A. Murena ("La tarea del traductor", en Walter Benjamin, Ensayos escogidos, 1999, México, Ediciones Coyoacán, pp. 77-88), así como la hecha al inglés por Harry Zohn ("The task of the translator", en Rainer Schulte y John Biguenet (eds.), Theories of translation: An anthology of essays from Dryden to Derrida, 1992, Chicago, The University of Chicago Press, pp. 71-82). A propósito de las circunstancias editoriales del texto, Benjamin lo "pensaba publicar en el primer número de la revista Angelus Novus. Como esta no llegará a publicarse, este texto lo utilizará como prólogo a sus traducciones [de Baudelaire] cuando fueron editadas por Richard Weisbach, en 1923" (Bruno Tackels, Walter Benjamin. Una vida en los textos, 2012, Valencia, Universitat de València, p. 113).

${ }^{2}$ La palabra comunicación (Mitteilung) tiene en el primer Benjamin dos sentidos, uno idealista y otro semiótico: se trata entonces o de la participación intrínseca de contenidos espirituales (Mitteilung geistiger Inhalte) en el lenguaje, o bien, de la emisión y recepción extrínsecas (äusserlich) de signos convencionales. En el último sentido, en el que se la usa en este momento, la palabra comunicación tiene una connotación despectiva.

${ }^{3}$ Die Aufgabe des Übersetzers, p. 9. 
se lee: “¿Qué ‘dice’ un poema? ¿Qué ‘comunica’? Muy poco, a quienes lo entienden. Por esencia no es comunicativo, ni declarativo. Mas cualquier traducción que pretenda desempeñar una función comunicativa, no puede comunicar sino información, es decir, algo inesencial. He aquí el signo distintivo de las malas traducciones". ${ }^{4}$

Estas afirmaciones resultan aberrantes si se las mira a través de la lente de una traductología de corte positivista que juzgue exitoso el proceso de trasvase textual cuando este se atenga a la "regla de oro" según la cual hay que decir en la lengua meta todo lo que el original dice en la lengua fuente, sin añadir nada que el original no diga, y además decirlo de la mejor manera posible en la lengua meta (esto es, según las pautas léxicas, sintácticas y pragmático-discursivas de esta última). Así las cosas, no causa sorpresa que, a la distancia de las décadas, algunos estudiosos de la traducción vean en el ensayo benjaminiano la más exacerbada exposición del literalismo traductológico tradicional. ${ }^{5} \mathrm{Si}$ bien es cierto que Benjamin indudablemente da pie a esta valoración - entre otras cosas por el hecho de concluir su texto afirmando que "la versión interlineal de las Sagradas Escrituras es el prototipo o ideal de cualquier traducción"- ${ }^{6}$ sería injusto con "La tarea del traductor" descartar en bloque la riqueza de sus tesis con el argumento de que el traductor moderno no puede derivar de ahí más que dos de las herramientas del repertorio de procedimientos de recodificación textual de los que un profesional dispone actualmente: el calco y, en mucho menor medida, la transposición.

Pese a la supuesta rigidez literalista del modelo teórico benjaminiano de la traducción, mi pretensión en este ensayo es mostrar de la forma más clara posible ciertos aspectos hermenéuticos del modelo que dependen del rendimiento heurístico de la noción de distancia fenomenológica, aspectos tanto más difíciles de discernir cuanto que

${ }^{4}$ Loc. cit.

${ }^{5}$ Véase, por ejemplo, Hans Störig, Das Problem des Übersetzens, 1973, Darmstadt, Wissenschaftliche Buchgesellschaft, p. 169; Mary Snell-Hornby, Estudios de traducción. Hacia una perspectiva integradora, 1999, Salamanca, Ediciones Almar, trad. de Ana Sofía Ramírez, p. 27.

${ }^{6}$ Die Aufgabe des Übersetzers, p. 21. 
Benjamin no fue propiamente un fenomenólogo, y además en su propuesta traductológica parece dejar un estrechísimo margen de maniobra a las operaciones interpretativas por parte del traductor.

2. Para empezar, importa no perder de vista que la teoría benjaminiana de la traducción es polifacética, y que muchas de sus caras no comparecerán en estas páginas; por citar solo dos, muy relevantes: la criptoteología judaica que permea y nutre a la teoría, así como la filosofía de la reine Sprache (o lenguaje puro), cuya exposición parcial recae en la traductología. Con todo, antes de sumergirnos en "La tarea del traductor" es indispensable hacer una caracterización preliminar de la rica noción benjaminiana de lenguaje, tal como la expone en el ensayo "Sobre el lenguaje en general y sobre el lenguaje de los humanos" (1916). ${ }^{7}$

En este texto Benjamin define el lenguaje como "un principio dedicado a la comunicación de contenidos espirituales relativos a los objetos respectivamente tratados" $"$ y lo concibe al modo de un medium comunicativo para todas las realidades, no solamente la humana: "la comunicación por medio de la palabra es solo un caso particular del lenguaje humano [...] Pero el ser del lenguaje no solo se extiende sobre todos los ámbitos de la expresión espiritual del hombre [...] sino que se extiende sobre todo". ${ }^{9}$ Ahora bien, este panlingüismo implica una estratificación: "las diferencias entre lenguajes son diferencias entre medios distintos en densidad, y por lo tanto, distintos en graduación". ${ }^{10}$

Según la densidad comunicativa del medium lingüístico, Benjamin piensa en por lo menos tres formas o niveles de lenguaje:

i) El nivel del ser creador, divino y omnisciente. En este sentido, su lenguaje es un nombramiento creador, es decir, un lenguaje de nombres,

${ }^{7}$ Como señala Tackels: "Cuando redacta en Múnich 'Sobre el lenguaje en general y sobre el lenguaje humano en particular', Benjamin tiene 24 años. Originalmente el texto no estaba destinado a ser publicado; debía sencillamente servir de apoyo escrito en las discusiones teológicas profundas entabladas con Scholem en los meses precedentes" (Bruno Tackels, op. cit., p. 79).

${ }^{8}$ Walter Benjamin, "Sobre el lenguaje en general y sobre el lenguaje de los humanos", en Para una crítica de la violencia y otros ensayos. Iluminaciones IV, 1991, Madrid, Taurus, trad. de Roberto Blatt, p. 59.

${ }^{9}$ Loc. cit.

${ }^{10}$ Ibid., p. 64. 
inmediatamente creador de las cosas nombradas por esos Nombres. La lógica del verbo divino es simple: al pronunciar el Nombre, Dios crea la cosa inmediatamente y la conoce integralmente al mismo tiempo. En el verbo divino, crear el ser, nombrar el ser y conocer el ser son una y la misma cosa.

ii) El nivel de la naturaleza y su lenguaje mudo. [...] Con este proceso de nombramiento-creación, las cosas advienen al ser como lenguaje, ya que realmente se trata, en el silencio de las cosas, de un lenguaje. Los seres mudos de las cosas proceden del lenguaje, salen directamente del lenguaje divino que les da el ser. Los nombres de las cosas no son otra cosa — según Benjamin - que los nombres pronunciados por Dios, pero vaciados, al final de esa pronunciación, de su sonoridad divina, de su poder creador. Así pues, las cosas conservan en silencio la marca silenciosa del nombre que las creó.

iii) El nivel de la realidad humana [...] Dios transmite a Adán el fabuloso poder de escuchar en el mutismo de la naturaleza el eco del nombre divino que preside su creación. Al escuchar la naturaleza, Adán recibe de Yahvé el poder de (re)nombrar las cosas, de proferir su nombre, el nombre por medio del cual Dios las creó. ${ }^{11}$

De acuerdo con la articulación de estos tres niveles, existe en la instancia del lenguaje adánico una posibilidad de reactivación o redención sonora del nombre divino silenciado y encapsulado en las criaturas no humanas después del acto performativo absoluto de su proferimiento/ creación por parte de Dios; al menos esta posibilidad se declara en el campo de lo paradisíaco. Pero en el contexto de la expulsión del Edén y la caída de Adán y Eva (cuyas consecuencias lingüísticas se hacen manifiestas en el relato de la torre de Babel) el lenguaje humano se degrada. Así las cosas, en el estrato del lenguaje humano se distingue el lenguaje adánico — que comunica la esencia de las criaturas — del lenguaje de

${ }^{11}$ Tackels, op. cit., pp. 535-536. A propósito de la importante diferencia entre lenguaje divino y lenguaje adánico: "Mientras que, en el lenguaje divino, el potencial creador y el cognitivo alcanzan una identidad absoluta, el lenguaje humano permanece deficitario en comparación con esta unidad de 'palabra' y 'nombre'. De acuerdo con su esencia no es creador sino cognitivo" (Uwe Steiner, "Crítica” (trad. de Mariela Ferrari), en Michael Opitz y Erdmut Wizila (eds.), Conceptos de Walter Benjamin, 2014, Buenos Aires, Las cuarenta, p. 251). 
signos convencionales, multiplicado en las lenguas posbabélicas, ${ }^{12}$ incapaz de otra tarea que la de señalar extrínsecamente las cosas:

El pecado original es la hora de nacimiento de la palabra humana, en cuyo seno el nombre ya no habita indemne. Del lenguaje de nombres, el conocedor, podemos decir que su propia magia inmanente salió de él para ser, expresamente, mágica desde afuera. Se espera que la palabra comunique algo (fuera de sí misma). Este es el verdadero pecado original del espíritu lingüístico. La palabra como comunicante exterior; esto es simultáneamente una parodia de lo expresamente inmediato y además la decadencia del espíritu lingüístico bienaventurado, el adánico, que se yergue entre ambos. ${ }^{13}$

En consideración de esta jerarquía onto-lingüística, en el ensayo de 1916 Benjamin apunta, a propósito de la traducción:

Es preciso fundamentar el concepto de traducción en el estrato más profundo de la teoría del lenguaje, porque es de demasiado e imponente alcance como para ser tratado a posteriori $[. .$.$] Alcanza su plena signifi-$ cación con la comprensión de que cada lenguaje superior, con la excepción de la palabra de Dios, puede ser concebido como traducción de los demás. La traductibilidad de los lenguajes está asegurada por el enfoque antes mencionado según el cual los lenguajes están relacionados por ser medios de diferenciada densidad. La traducción es la transferencia de un lenguaje a otro a través de una continuidad de transformaciones. La traducción entraña una continuidad transformativa y no la comparación de igualdades abstractas o ámbitos de semejanza. ${ }^{14}$

A partir de estos elementos podemos acotar la noción de traducción que estudiaremos en el ensayo "La tarea del traductor". Se trata en este caso de la traducción, no en su sentido omniabarcante, sino en el bien

${ }^{12}$ Sobre las implicaciones comunicativas, pragmáticas y traductológicas del mito de Babel en el pensamiento de Benjamin, véase Jacques Derrida, "Des Tours de Babel”, en Psyche I, 1987, París, Galilée, pp. 203-236.

${ }^{13}$ Walter Benjamin, "Sobre el lenguaje en general y sobre el lenguaje de los humanos", pp. 70-71.

${ }^{14}$ Ibid., p. 69. 
específico de la traducción interlingüística, es decir, la que, en términos de Benjamin, se practica de un lenguaje semiótico (verbal) a otro, ambos situados en el mundo humano posbabélico, ambos constituidos y afectados por la exterioridad y la intencionalidad de palabras que apuntan como signos hacia las cosas, o bien — en el acompasamiento de la lengua fuente con la lengua meta - hacia otras palabras en otro idioma.

3. Para continuar, resulta imperativo esclarecer algunos supuestos fenomenológicos sobre la naturaleza del lenguaje que gobiernan el modelo traductológico benjaminiano tal como se expone en Die Aufgabe des Übersetzers. En la consideración de los componentes verbales y discursivos de una lengua, pero sobre todo en lo tocante al léxico, Benjamin distingue entre la intención lingüística (Intention) y el modo de significar(Art des Meinens). Según esto, dos sinónimos interlingüísticos como la palabra alemana Brot y la palabra francesa pain (equivalentes al castellano 'pan') comparten la intención y difieren en el modo de significar. Como sería engañoso analogar esta distinción a la existente entre los conceptos de denotación y connotación, conviene intentar reformularla según la pauta de la fenomenología husserliana.

De acuerdo con esta fenomenología la forma de todo acto de pensamiento - incluidos los que se hacen en el dominio del lenguaje - es la intencionalidad, es decir, el esfuerzo de atención dirigida que la conciencia despliega hacia su objeto: "Entendemos por intencionalidad la peculiaridad de las vivencias de 'ser conciencia de algo [...] En todo cogito actual, una 'mirada' que irradia del yo puro se dirige al 'objeto' que es el respectivo correlato de la conciencia, a la cosa, la relación objetiva, etc., y lleva a cabo la muy diversa conciencia de él". ${ }^{15}$ Según esta tópica de la conciencia, cada acto intencional emana de un polo pensante, o noético, y alcanza su destino en un polo pensado, o noemático, lo cual implica que el proceso pensante, o noesis, comprende una estructura dual, así como una distancia y una correlación entre los dos polos.

${ }^{15}$ Edmund Husserl, Ideas relativas a una fenomenología pura y una filosofía fenomenológica, 1992, México, Fondo de Cultura Económica, trad. de José Gaos, p. 198. 
A propósito de esa distancia constitutiva, cabe insistir en que, por su causa, toda intelección es intelección de algo trascendente al yo que intelige y hacia lo cual dirige un rayo de atención para captarlo; la conciencia no ejecuta sus operaciones representativas en la inmanencia del polo intencional, sino que tiene que volcarse a la exterioridad del polo intencionado para apoderarse ahí de su objeto. Como veremos, este apuntar hacia fuera y salir de sí la conciencia hacia su objeto es el componente de la intencionalidad husserliana del que Benjamin obtiene más provecho heurístico en su teoría de la traducción.

Ahora bien, tanto si en el polo intencionado se capta un contenido de naturaleza eidética (por ejemplo: una figura geométrica), como si el contenido es de índole perceptiva (es decir, un escorzo de la realidad empírica), es preciso distinguir entre la captación intencional en puridad y sus modalidades. La diferencia entre, digamos, un gato percibido y el mismo gato recordado o imaginado o inclusive soñado no es de orden eidético: el gato intencionado es fenomenológicamente el mismo en esos distintos actos; los que divergen son los actos noéticos que captan al gato, y divergen de acuerdo con las modificaciones de conciencia a través de las cuales se intenciona un solo y mismo eidos gatuno (en el modo del ver, en el del evocar, en el del libre fantasear, en el del soñar). ${ }^{16}$ Hasta aquí Husserl.

4. Si ahora extrapolamos la noción de intencionalidad al universo temático de "La tarea del traductor", notaremos una analogía entre ella y la 'intención lingüística' de Benjamin, y otra entre la 'modalidad intencional' del primer filósofo y el 'modo de significar' del segundo. "En las palabras Brot y pain lo intencionado es lo mismo, pero el modo de significar no lo es", ${ }^{17}$ dice Benjamin. En otros términos: si, abusando de la prosopopeya, nos figuramos a estas dos palabras como focos de intencionalidad, entonces, desde un punto de vista referencial, ambas apuntan hacia el mismo correlato eidético: ese alimento que en español llamamos

${ }^{16}$ A propósito de las modalidades intencionales y la invariancia eidética, véase Edmund Husserl, Ideas relativas a una fenomenología pura y a una filosofía fenomenológica, § 99 "El núcleo noemático y sus caracteres en la esfera de las percepciones y las representaciones", pp. 243-245.

${ }^{17}$ Die Aufgabe des Übersetzers, p. 14. 
'pan', ${ }^{18}$ en tanto que desde un punto de vista semántico, cada cual se apodera de ese correlato según una modalidad idiomática propia.

Ahora bien, ¿en qué consiste esta modalidad? El autor se limita a decir que "es por el modo de significar que estas palabras son distintas para un alemán y para un francés". ${ }^{19}$ Nada nos impide suponer que el 'modo de significar' de una palabra (o, al menos, de una palabra categoremática) está conformado por un haz de rasgos que, por motivos que explicaré un poco más adelante, nos conviene imaginar como un revestimiento del núcleo eidético del vocablo mismo. Este haz incluye las características fónicas y morfológicas de la palabra, su comprensión y extensión semánticas, sus posibilidades combinatorias en el nivel sintáctico, así como el espectro de sus valores pragmático-discursivos. Enfocado el asunto de este modo, puede resultar más claro por qué, insertas en sus respectivos sistemas de lengua y contextos culturales, las palabras Brot y pain "no son intercambiables" e inclusive "se esfuerzan por excluirse", ${ }^{20}$ es decir, sus respectivos dominios modales no son conmensurables.

De hacer en este punto de la exposición el intento de reconstruir en una figura coherente los postulados de Benjamin que he mencionado, el resultado que obtendríamos sería descorazonador. Me explico: si el aspecto netamente comunicativo de una lengua reside en el ámbito de lo ideal puro, y si además el modo de significar de esta es tan idiomático que resulta incompatible con el de otra, entonces el único recurso del traductor literario es desprender el contenido eidético del texto fuente de su revestimiento modal aborigen para envolverlo en una piel modal distinta y, en el mejor de los casos, equivalente a la previa: la de la lengua meta. Pero ello es estéril, pues en el caso de la obra literaria lo comunicativo es inesencial y lo decisivo está configurado según el modo de significar. Comienza uno aquí a sentir el peso de la célebre afirmación benjaminiana: "no hay musa de la traducción". ${ }^{21}$

${ }^{18}$ Ahora bien, que para realizar esa indicación referencial cada una de esas palabras deba constituir el objeto empírico 'pan' en el polo intencionado de un acto de significación denotativa, es decir, en el componente semántico de su propio código, es asunto ajeno a las reflexiones de Benjamin.
${ }^{19}$ Loc. cit.
${ }^{20}$ Loc. cit.
${ }^{21}$ Ibid., p. 16. 
5. Con todo, hay otro camino para traducir sin confinarse en la esterilidad de la recodificación de un contenido inesencial y sin quedar varado en la inconmensurabilidad de dos modos excluyentes de significar. Pero para entrar en él es preciso repensar el proceso traductológico en los términos más isomorfos que se pueda con la arquitectónica de la intencionalidad fenomenológica. Recordemos entonces: en todo acto intencional la conciencia representativa está separada de su contenido, no fusionada con él; la distancia entre el polo intencional y el polo intencionado es la clave del asunto; para que el intelecto capte su objeto tiene que llegar a él desde lejos y desde fuera. En este orden de cosas, Benjamin tematiza la distancia fenomenológica en por lo menos tres pasajes de "La tarea del traductor".

Así, a propósito de la manera en que el poeta y el traductor se relacionan con los contenidos eidéticos lingüísticos, nuestro filósofo apunta: "la intención del poeta es inmediata, primera, intuitiva; la del traductor, derivada, última, conceptuosa." ${ }^{22}$ Dicho de forma menos hermética, la intencionalidad del texto traducido está más lejos del contenido noemático primario que la del texto fuente, pues para llegar a él tiene que pasar por el tamiz del modo de significar de este, atravesando esa membrana modal. Cabe, sin embargo, preguntarse si el texto traducido logra cruzar la barrera semántica del original o si esta es impermeable, es decir, si está constituida no tanto como membrana, sino más bien a la manera de una coraza esmaltada que solo se deja intencionar a sí misma, ofreciéndosele como objeto primario al texto de la traducción, cuyos esfuerzos por traspasarla, que la coraza repele, no logran acceder al núcleo noemático del texto original.

Esta parece ser la certeza de Benjamin, tal como se desprende del segundo de los pasajes del texto, en donde se hace rendir heurísticamente al concepto de distancia fenomenológica: "La relación entre contenido y lenguaje es muy diferente en el original y en la traducción. Estos forman ciertamente una unidad en el original, como la de una fruta y su piel, en tanto que el lenguaje de la traducción envuelve su

${ }^{22}$ Loc. cit. 
contenido como un manto real de amplios pliegues". ${ }^{23}$ Supongamos una fruta, una ciruela, no demasiado madura, de pulpa firme y con la piel perfectamente ceñida a la carne: he aquí una imagen de la adecuación exacta entre el contenido noemático del texto original (la pulpa) y el modo de significar de la lengua en que está codificado (el tegumento). Ahora representémonos el modo de significar del texto traducido como un tejido menos flexible y, sobre todo, no adherido por naturaleza a ningún objeto al que, aun así, cubriera... ¿Cuál sería su contenido? No queda más que responder: el texto fuente. Así las cosas, la fruta del texto original envuelta en el manto de la traducción tendría un aspecto distinto recubierta por él que desnuda, y, puestos a juzgar si bajo el manto se oculta una ciruela, el juicio solo podría ser hipotético.

Además, no perdamos de vista la imposibilidad de acercar todavía más la tela de la traducción a la pulpa del original: el intento de recubrirla directamente con el manto sería un despropósito: habría que desollar la ciruela primero, y luego adherirle — prótesis fallida — una absurda piel de tela. Ante estas dificultades, el texto traducido tiene que resignarse a quedar separado del contenido del texto original por la película impermeable del modo de significar del original mismo; en otras palabras, el texto meta nunca puede llegar a la pulpa noemática del texto fuente, ni por su designio ni según una intuición empática (una vez más: "no hay musa de la traducción"), sino que debe esforzarse en ceñir los accidentes semánticos del original con su propio modo de significación, pues esos accidentes semánticos son el único objeto al alcance de su intencionalidad. Abocada a cumplir este propósito, la traducción (ese texto que envuelve otro texto) ha de procurar satisfacer lo mejor posible dos exigencias: la primera, no perder contacto con la superficie lingüística del original; la segunda, no romperse en el esfuerzo de mantener ese contacto. En el orden de la técnica traductológica, Benjamin postula algo casi imposible de lograr: traducir calcando al máximo y trasponiendo al mínimo.

En un tercer pasaje del texto, la arquitectónica de la distancia fenomenológica se presenta en los términos de un complejo metafórico

${ }^{23}$ Ibid., p. 15. 
distinto: "La traducción no se encuentra, como la obra poética, dentro del bosque del lenguaje, sino que desde fuera, frente a él, y sin meterse en él, dirige sus llamados al original hacia los lugares en los que el eco puede repetir, en el idioma de la traducción, la resonancia de la obra en el idioma extranjero". ${ }^{24}$ Como en el símil de la fruta, hay aquí una lejanía que no se deja abreviar y que impide que el traductor se adentre en el bosque de la lengua fuente, donde se escabulle el texto original; como en los cuentos maravillosos, si el cazador se interna en ese bosque corre el riesgo de perderse y no salir; en cambio, la renuncia a apoderarse de la pieza por propia mano se compensa con la posibilidad de atraparla desde lejos, con una trampa sonora: buscando el ángulo adecuado para lanzar enunciados en la lengua meta y estimar la fidelidad de su respuesta en la lengua origen, la traducción puede lograrse como eco del original. ¿Y acaso el eco no puede analogarse a un envoltorio, a una capa de sonido que deja escuchar la forma que reviste? Si Benjamin hubiera conocido los aparatos de ultrasonido, quizá los habría juzgado máquinas traductoras: traductores ecográficos. Por cierto, notemos que en este caso la película sonora corre los mismos riesgos que su análogo textil en la metáfora de la fruta: distorsionarse por holgura o reventar en el silencio por un excesivo esmero de precisión.

Llegados aquí, es admisible transcribir las palabras con que Benjamin formula la tarea del traductor: "Consiste en encontrar, en el idioma al que se traduce, aquella intención lingüística que pueda despertar en este el eco del original". ${ }^{25}$ Digámoslo una vez más: no se trata de encontrar el eco que arroje en la lengua meta el contenido eidético del original (pues este solo es accesible desde el original), sino el eco producido por la refracción de la intencionalidad lingüística del texto meta en la superficie del texto fuente.

6. Ahora bien, una vez comprendido el pensamiento traductológico de Benjamin en su sentido, digamos, artesanal, cabe preguntarse si la traducción así concebida alcanza el estatuto de actividad hermenéutica solamente en este plano operativo. En efecto, buscar en la lengua

${ }^{24}$ Ibid., p. 16.

${ }^{25}$ Loc. cit. 
meta un eco del original implica realizar conjeturas lingüísticas complejas a favor de la comparación de dos universos idiomáticos inconmensurables, conjeturas que no pueden aspirar al estatuto de casos de una regla, ni siquiera al de máximas procedimentales, en la medida en que la sobreabundancia de elementos heterogéneos que el traductor tiene que ajustar mientras realiza su trabajo ecográfico rebasa las posibilidades de generalización de cualquier fórmula. No se me malinterprete: no pierdo de vista que el ámbito conjetural en el que se mueve el traductor tiene unos límites normativos: los de las leyes sistémicas de las lenguas con las que trabaja; solamente busco destacar que el ejercicio de jurisprudencia que el traductor tiene que sacar adelante para cumplir con la tarea benjaminiana es, por así decirlo, infinitesimal. Dicho en otros términos: a partir de un corpus de traducciones ecográficas "exitosas", por amplio que fuere, no podría construirse una normativa traductológica, sino que habría que conformarse con estudiarlo en términos casuísticos.

Solo esto bastaría para no despreciar el aspecto artesanal de la traducción, y el propio autor así lo estima. Un pasaje del ensayo, que ya cité incompleto dos veces, reza: "No hay musa de la filosofía, tampoco hay musa de la traducción. Prosaicas, ${ }^{26}$ empero, como los artistas sentimentales desearían que fueran, ni una ni otra lo son". ${ }^{27}$

No obstante lo dicho, sabemos que el alcance del término hermenéutica es más amplio. Cuando menos desde Verdad y método (1960), gracias a la reconstrucción histórica que hace Gadamer del Ars interpretandi, estamos al tanto de que la hermenéutica no es solo una tejné, ni nada más el paradigma metodológico de comprensión de las ciencias idiográficas (las Geisteswissenschaften de Wilhelm Dilthey), sino sobre todo una forma humana de ser en el mundo y, por extensión, una disposición cognitiva y un modo simbiótico de relación con las entidades culturales. Es en este orden de significación de la palabra hermenéutica que vale la pena emprender un segundo recorrido por el texto de

${ }^{26}$ Benjamin usa el adjetivo banausisch, que etimológicamente significa 'artesanal', pero en sentido corriente es término peyorativo: 'inculto', 'agreste', 'pedestre'.

${ }^{27}$ Ibid., pp. 16-17. 
Benjamin con el afán de valorar el rendimiento gnoseológico de la traducción literaria.

En uno de los escasos pasajes del ensayo que proveen definiciones positivas, el autor apunta: "La traducción es una forma (Form). Para captarla como tal, hay que volver al original, pues en él yace su ley, la cual decide su traducibilidad (Übersetzbarkeit)". ${ }^{28}$ Comprendemos ya que la traducción es literalmente una forma lingüística que reviste a otra; lo interesante ahora es explorar el concepto de traducibilidad. Benjamin encuentra en él dos sentidos:

La pregunta por la traducibilidad de una obra es doble. Puede significar: ¿encontrará la obra en la totalidad de sus lectores alguna vez un traductor? O bien, y más propiamente, ¿admite traducción la esencia de la obra y, por lo tanto, según su modo de significar, anhela esa traducción? En principio, la primera pregunta solo admite una respuesta problemática; la segunda, una respuesta apodíctica. ${ }^{29}$

Para el autor, "solamente una mentalidad superficial" consideraría ambas preguntas de igual peso, o bien, negaría la independencia de la segunda respecto de la primera. En efecto, solo en el terreno contingente de los hechos puede saberse si una obra literaria ha logrado ser traducida. Cosa muy distinta es afirmar que "la traducibilidad de las creaciones lingüísticas debe tomarse en cuenta incluso si ellas fueran intraducibles para los humanos [...] La traducibilidad es una propiedad esencial de ciertas obras, lo cual no significa que sea esencial que se las traduzca, sino que una significación específica radicada en el original se manifiesta en su traducibilidad". ${ }^{30}$

A manera de glosa a los pasajes citados: cada obra literaria es única, un individuo verbal, un singular, y no un caso discursivo particular subsumible sin más en un repertorio de universales lingüísticos. Por eso la traducibilidad del texto literario es facultad propia de cada obra, y por eso también la cuestión de si una obra es traducible tiene que ver

${ }^{28}$ Ibid., p. 9.

${ }^{29}$ Loc. cit.

${ }^{30}$ Loc. cit. 
en lo esencial con su modo de significar y no con el hecho contingente de si un traductor empírico es capaz de acercarse desde otra lengua a ese modo de significación.

Pero lo decisivo, a mi entender, es que Benjamin postula (al menos en el caso de ciertas obras, aunque no especifique cuáles) la existencia de significaciones inherentes a los textos literarios que permanecen embrionarias en ellos mientras no son trasladadas a otra esfera lingüística. En esta idea se aloja en su sentido más noble el rendimiento hermenéutico de la traducción. Me explico: la obra literaria, inmersa en su medio lingüístico aborigen, no expresa exhaustivamente su potencial semántico; tan solo puede hacerlo si se expande en otro medio lingüístico, el de su traducción. Recordemos por un momento la arquitectónica de la distancia entre texto fuente y texto meta que revisamos más arriba: en aquel momento la orientación axiológica de la distancia conducía de la traducción al original, según un movimiento, digamos, centrípeto de adecuación entre un texto derivado y más lejano del núcleo eidético (la traducción) y un refractario texto original que acaparaba el eidos para sí y le daba la espalda al manto que lo cubría. En este momento es necesario que cambiemos la orientación axiológica de la distancia entre original y traducción a favor de la segunda: ya se la vea como un vestido, ya como un eco del original, lo notable ahora es que la traducción expresa rasgos de significación del original que no podían manifestarse desde la desnudez, o bien, desde el emboscamiento de este. Así pues, la traducción también consigue enriquecer el universo semántico del texto fuente.

A este respecto, debo admitir que Benjamin es menos entusiasta que yo, al menos estilísticamente. El autor concibe el vínculo entre el original y la traducción como "vital" (ein Zusammenhang des Lebens), ${ }^{31}$ pero formula esa vitalidad de esta manera: "[la traducción] mantiene por la fuerza de la traducibilidad un vínculo de cercanía con el original; este vínculo es tan íntimo justamente porque para el original carece de importancia [...] Así como las manifestaciones de vitalidad están íntimamente vinculadas a los seres vivos sin tener importancia para

${ }^{31}$ Ibid., p. 10. 
ellos, así la traducción emana del original, no tanto de su vida como de su 'supervivencia' (Überleben)". ${ }^{32}$ El último pasaje es críptico, sobre todo por la ambigüedad del término Überleben, que en este contexto no debe entenderse como si Benjamin sugiriera que el original necesita las traducciones para mantenerse vigente en el ámbito histórico de la recepción, ${ }^{33}$ sino más bien como si esa "sobre-vida" o inclusive "ultravida" del original señalara un excedente, una irradiación, superflua para su fuente, tan irrelevante para ella como resultan espontáneas y, por así decir, suntuarias para la conservación de un ser viviente sus meras manifestaciones de vitalidad. Esta lectura del pasaje la confirma otro: "[las traducciones] no están al servicio de la obra — como pretenden los malos traductores para justificar su trabajo_-, sino que a ella deben agradecer su existencia. En las traducciones alcanza la vida del original su siempre renovado, más amplio y último despliegue". ${ }^{34}$

En suma, me parece que una posición crítica ecuánime a propósito del vínculo que según Benjamin une al original con la traducción sería la siguiente: aunque para la 'vida' lingüística del original es indiferente llevar a eclosión en otra lengua las esporas de sentido que no lograron estallar en el idioma aborigen, es decir, aunque para la 'fisiología' semántica del original la traducibilidad embrionaria es un apéndice supernumerario, ello no niega que el esfuerzo hermenéutico de gestar el sentido de ese embrión amplía el ámbito de significación de la obra, de modo que ella logra desplegar una atmósfera semántica nueva, a la que no se puede acceder desde el monolingüismo del original.

7. Evaluemos una última vez, y por la vía del excurso, el rendimiento hermenéutico de esta facultad expansiva de la traducción. En su tesis doctoral, presentada en la Universidad de Berna en 1918 y editada dos años después con el título de El concepto de crítica de arte en el romanticismo alemán, Benjamin dedica largos tramos de la argumenta-

${ }^{32}$ Loc. cit.

${ }^{33}$ Independientemente de que las traducciones puedan fungir como índices en la escala de la recepción epocal de la obra. Dice al respecto Benjamin: "Las traducciones que hacen algo más que comunicar, surgen cuando una obra ha alcanzado la época de su fama" (ibid., p.11).

${ }^{34}$ Loc. cit. 
ción a exponer el alcance epistemológico de la filosofía romántica de la reflexión. Este no es el lugar adecuado para entrar en detalles acerca del modo en que el autor explica cómo el concepto de reflexión de Fichte estimuló el surgimiento del paradigma de la crítica literaria de Friedrich Schlegel, así como desencadenó el llamado 'idealismo mágico' del poeta Novalis; aun así, nos conviene retener de la exposición benjaminiana dos o tres postulados básicos de esa filosofía.

Primero, que la reflexión o autoconciencia representa para la mera conciencia un incremento de saber: en efecto, saber que se sabe, el saber mediado en su reflejo, es cualitativamente superior al saber de primer grado de la conciencia inmediata, pues el que meramente sabe, no sabe que sabe. Segundo, que la autoconciencia puede iterarse en sucesivos niveles de reflexión indefinidamente, de lo cual se sigue que el proceso del saber es progresivo (pues avanza de nivel reflexivo en nivel reflexivo) e interminable (pues la reflexión tiene la estructura de una construcción en abismo). Tercero, que la autoconciencia no es privativa del sujeto pensante, sino que también participa de ella el objeto con el que el sujeto establece la relación epistémica. Este último punto es decisivo: "No solamente los hombres pueden ampliar su conocimiento a través de los grados superiores del autoconocimiento en la reflexión, sino también, y en la misma medida, los objetos naturales", ${ }^{35}$ escribe Benjamin; a lo que añade: "Observar una cosa significa empujarla hacia el autoconocimiento. Que el experimento alcance el éxito depende de en qué medida el experimentador esté en condiciones de aproximarse al objeto y de incluirlo en sí", 36 e inclusive agrega: "En la base de este experimento no yace ninguna interrogación a la naturaleza. Antes bien, la observación considera el autoconocimiento germinal en el objeto, o más bien ella misma, la observación, constituye ese autoconocimiento germinal del objeto". ${ }^{37}$

En el paradigma epistemológico del romanticismo alemán, no solo los seres naturales no humanos son susceptibles de autoconciencia: de

${ }^{35}$ El concepto de crítica de arte en el romanticismo alemán, 1995, Barcelona, Península, trad. de J. F. Yvars y Vicente Jarque, p. 89.

${ }^{36}$ Ibid., p. 92.

${ }^{37}$ Ibid., p. 93. 
manera análoga al naturalista "experimentador", que logra conocer una criatura cuando irrita en ella el germen de la reflexión, así el crítico literario cumple con su tarea, no al evaluar con patrones extrínsecos a la obra su rendimiento estético, sino más bien cuando consigue aguijonear en ella su "criticabilidad", es decir, al permitir que el sentido de la misma acceda a un nivel de reflexión superior en el discurso crítico que él elabora: "La crítica es algo semejante a un experimento en la obra de arte, en virtud del cual se estimula la reflexión por la que la obra es elevada a la conciencia y al conocimiento de sí misma". ${ }^{38}$ En este caso: "El sujeto de la reflexión es, en el fondo, el producto artístico mismo, y el experimento no consiste en la reflexión sobre un producto, que no podría esencialmente transformarlo [...] sino en el despliegue de la reflexión — esto es, del espíritu-en el producto". ${ }^{39}$

Hasta aquí la digresión. Como puede verse, en el pensamiento del primer romanticismo alemán, la crítica literaria, de modo análogo al paradigma benjaminiano de la traducción, cumple el papel hermenéutico de expandir el sentido del texto que critica: un sentido endógeno, seminal, que el crítico literario ayuda a manifestar, así como el traductor idóneo es el agente de germinación de una semilla lingüística trasterrada a otra lengua; en ambos casos, el crítico y el traductor cumplen con su encomienda "solo cuando estos no son intelectos empíricos, sino niveles de reflexión [de la obra] personificados" ${ }^{40}$ En concordancia con esto, criticabilidad y traducibilidad son en el pensamiento benjaminiano términos homólogos, e incluso es plausible pensar que la traducibilidad de la que se ocupa el ensayo de 1923 es un caso concreto de apropiación por parte de Benjamin de la más amplia idea de criticabilidad que encontró en los románticos que protagonizan la tesis de 1918. Una confirmación de este último aserto lo encontramos en una glosa a una cita de Novalis, que se halla justo en este último libro:

En ejemplos de esta crítica positiva y plenificadora está pensando Novalis cuando, a propósito de cierta clase de traducciones a las que denomina

${ }^{38}$ Ibid., p. 101.

${ }^{39}$ Loc. cit.

${ }^{40}$ Ibid., p. 104. 
míticas dice: "Estas representan el carácter acabado y puro de la obra de arte individual. No nos dan la obra de arte real, sino el ideal de la misma [...]". En la medida en que aproxima recíprocamente crítica y traducción, tal vez Novalis piensa en una permanente transposición mediática de la obra desde un lenguaje al otro, una concepción que, partiendo de la naturaleza infinitamente enigmática de la traducción, resulta tan lícita como cualquier otra. ${ }^{41}$

A mi parecer, esas traducciones míticas que tienen la virtud de llevar a la obra literaria a su acabamiento, y en las que Novalis tal vez pensó como ideales, son un punto de partida del modelo traductológico que Benjamin propuso en "La tarea del traductor" algunos años después de su estudio sobre los románticos alemanes, modelo del que yo he querido ofrecer aquí un perfil, si bien incompleto, ojalá que nítido.

${ }^{41}$ Ibid., p. 107. 


\section{EL CONCEPTO DE "OPINIÓN PÚBLICA" EN MÉXICO (1820-1828)}

Gerson Moreno Reséndiz*

RESUMEN: Mediante el análisis del concepto de opinión pública, se pretende resaltar la importancia política que tuvo en el desarrollo de la vida social y cultural de la primera mitad del siglo XIX mexicano. Su relevancia política radicaba en que a través de la opinión pública se quería sustentar la soberanía nacional surgida de la voluntad general. Sin embargo, la historia de los conceptos develará, además, que en la práctica política la reflexión sobre cómo formar opinión pública y quiénes pueden formarla, segmenta espacios sociales, genera mecanismos de inclusión y exclusión, y, sobre todo, propicia estados de ánimo derivados de la experiencia y la expectativa social.

\section{sose \\ THE IDEA OF “PUBLIC OPINION” IN MEXICO (1820-1828)}

ABSTRACT: Through an analysis of the concept of "public opinion", we will highlight its political importance in the development of Mexico's social and cultural life in the first half of the nineteenth century. Its political significance lies in that national sovereignty, originating from the people's will, was supported through public opinion. However, by studying the history of these concepts we will show that in the political exercise the reflection on the origin of a public opinion and of those who shape it divides the social sphere, produces inclusionary and exclusionary mechanisms, and above all facilitates certain moods due to social expectations and experiences.

PALABRAS CLAVE: opinión pública, diacronía, sincronía, Iturbide.

KEY WORDS: public opinion, diachrony, synchrony, Iturbide.

RECEPCIÓN: 8 de abril de 2016.

APROBACIÓN: 6 de septiembre de 2016.

* Doctor en Historia por la Universidad Iberoamericana. 
CITAM Derechos Reservados.

La reproducción total o parcial de este artículo se podrá hacer si el ITAM otorga la autorización previamente por escrito. 


\section{EL CONCEPTO DE "OPINIÓN PÚBLICA" EN MÉXICO (1820-1828)}

\section{Introducción}

\section{El término opinión pública está tan inte-} riorizado por la sociedad contemporánea que ha perdido totalmente su sentido de conflicto; es decir, en la actualidad los sectores de la sociedad han llegado a un consenso sobre cómo se forma la opinión pública. Para gran parte de las teorías modernas, la opinión pública se forma poniendo en circulación en el espacio social una gama de opiniones individuales sobre los asuntos de interés público. Según estas teorías, las opiniones vertidas tienen su origen en las diferentes formas comunicativas humanas (periódicos, radio, televisión, internet). De esta manera, las opiniones, al circular por los medios masivos de comunicación llevan a las diferentes teorías a considerar a estos medios como los formadores de la opinión pública o, de cierta manera, como fuertes influencias. ${ }^{1}$

Esto no era así para la sociedad mexicana de principios del siglo XIX. Los espacios de la publicidad moderna - los espacios en donde las opiniones privadas se transforman en públicas - eran totalmente nuevos, y la instauración de la libertad de imprenta fue para las élites cultas

${ }^{1}$ Cfr. Raúl Rivadeneira Prada, La opinión pública: Análisis, estructura y métodos para su estudio, 1995, México, Trillas; K. Young et al., La opinión pública y la propaganda, 2001, México, Paidós, trad. de Eliseo Verón y Jorge Siroli; Manuel Mora y Araujo, El poder de la conversación. Elementos para una teoría de la opinión pública, 2005, Buenos Aires, La Crujía. 
una de las "cosas más dignas para la ilustración de las naciones". El establecimiento de la libertad de imprenta facilitó la circulación de los periódicos, en los que cualquier persona podía dar su opinión acerca de los asuntos de interés público. No obstante, muy temprano esas mismas clases mostraron su desagrado y desprecio por las opiniones vertidas en "producciones indigestas enemigas del buen gusto [que] brotan a cada momento; sus prematuros partos se venden al vulgo inepto como rasgos admirables de elocuencia". ${ }^{2}$ A la par de los periódicos, las producciones "indigestas" se difundían en papeles sueltos llamados "panfletos", en los cuales se publicaban fábulas, cuentos, diálogos y libelos infamantes con el fin de insultar y criticar las decisiones, los actos y la persona de los actores políticos encargados del gobierno. Estas publicaciones, debido a su carácter sedicioso, comenzaron a ser relacionadas por las élites en el gobierno con una opinión vulgar, disgregadora de toda unión y orden social y, de esta forma, fueron consideradas como una opinión falsa, no constitutiva de opinión pública. Como contraparte, la verdadera opinión u "opinión pública" era relacionada con las opiniones útiles, virtuosas, racionales y de buen gusto, de lo que hay que entender que se refería a las opiniones vertidas por las élites en el poder y en consonancia con las decisiones del gobierno en turno.

Al circular diferentes tipos de opiniones en el espacio público, unas ciertas y virtuosas, las otras falsas y vulgares, el problema fundamental de la sociedad mexicana de inicios de la vida independiente consistió en aprender a distinguir entre la "verdadera" opinión pública y la opinión "falsa" y "sin fundamento", y desde luego, discernir quiénes eran sus portadores. En estos puntos radica el carácter polémico del concepto de opinión pública, pues en el ámbito político y social los individuos, grupos, facciones o partidos luchan por presentarse como los portadores de la "verdad" y "constituyentes de opinión". Con ello, sus acciones quedaban justificadas, pues la lucha que emprendían era en pos de la opinión pública o la voluntad de la nación. La polémica de ninguna

${ }^{2}$ La vapulación más cruel a escritores miserables, 1820, México, Imprenta de D. Alejandro Valdés, 5 p., Fondo Reservado de la Biblioteca Nacional de México (en adelante FRBNM), Colección Lafragua, Laf.260, ficha 21. 
forma era insignificante, pues los actores políticos de la época consideraban a la opinión pública el sostén de la soberanía política vertida del orden republicano.

\section{Qué es y cómo se forma la opinión pública}

En 1820, en las páginas de El Hispano-Americano Constitucional, Lorenzo de Zavala inició una serie de artículos intitulados "Cómo se forma la opinión pública". La definición de opinión pública con que comienzan los artículos le sirvió como punto de partida para su formulación:

Así como la voluntad general de un pueblo, que se expresa por medio de las leyes, es la reunión de las voluntades particulares de los ciudadanos acerca de los objetos de interés general, así la opinión pública no es ni puede ser otra cosa sino la coincidencia de las opiniones particulares en una verdad de que todos están convencidos. Cimentada ya por la reunión, que es el origen de la fuerza, la opinión general, entonces en vano se opondrán los intereses y las miras particulares a la voluntad de todos, que está encerrada en la opinión. ${ }^{3}$

Formada por la reunión de las voluntades particulares en pública discusión sobre los problemas que atañían al común, de la voluntad de la mayoría o la opinión general irrumpía la opinión pública. En otras palabras, en un espacio de participación y discusión racional emergía la opinión pública. Esta visión optimista del concepto de opinión pública abría la posibilidad de fundamentar un ambiente de esperanza sobre futuros acuerdos con miras al bien público.

Esta posibilidad y este optimismo todavía se mantuvieron en las sesiones del Constituyente Mexicano, instalado el 24 de febrero de 1822. En la sesión del 17 de junio, el diputado Martín Inclán dijo que no hallaba otra solución para conocer el bien público, que el público

${ }^{3}$ Lorenzo de Zavala, "Cómo se forma la opinión pública", El Hispano-Americano Constitucional, 13 de junio de 1820, citado en Elías José Palti, La invención de una legitimidad. Razón y retórica en el pensamiento mexicano del siglo XIX, 2005, México, FCE, pp. 77-78. 
mismo. "Hable el pueblo: escúchese su opinión; y generalizada esta, se formará el que todos los políticos llaman espíritu público: este grande agente de todos los gobiernos liberales que en expresión de un sabio, reina en el mundo suave, pero más poderosamente que las armas de los tiranos". ${ }^{4}$ Hay que puntualizar, sin embargo, que la noción de opinión pública expuesta no implicaba la opinión de cualquier persona ni mucho menos la del "vulgo ignorante", que las élites de la época veían con miedo y desprecio. La parte del "pueblo" al que hacía referencia el señor Inclán conformaba la parte "ilustrada" de la sociedad mexicana, pues más adelante continuaba argumentando:

No confundo la voz popular con la opinión pública: esta en su genuina definición, es la expresión general del pueblo convencido de la verdad, que ha examinado por medio de la discusión; cuando aquella es el efecto del error, de la ignorancia de la violencia, de otras causas: por eso no se debe oír al vulgo ignorante, sino a la parte ilustrada del pueblo [...] No hay ni puede haber otro tribunal para decidir de la opinión pública, que el tribunal de la razón y del sentido general de los hombres. ${ }^{5}$ [Las cursivas son mías.]

Al mismo tiempo, reflexionaba que los hombres no podían juzgar ni explicar su parecer si no se escribía con mayor libertad. A su juicio, no había nada de malo en hablar sobre las bases del Plan de Iguala y los Tratados de Córdoba si estos no resolvían los problemas de la nación y al hacerlo solo se buscaba el bien público: "Mientras los escritos no se publiquen; mientras la nación no pueda juzgar de ellos y examinar sus ideas [sic], no podrá contribuir en nada a la formación de la opinión pública, cuya administración es peculiar de los ciudadanos, y no de magistratura alguna; así como la razón debe ser el único juez, y la discusión el procedimiento más necesario". ${ }^{6}$

${ }^{4}$ Sesión del 17 de junio de 1822, en Fernando Zertuche Muñoz y Felipe Remolina Roqueñí (coords.), Enciclopedia Parlamentaria de México, serie I: Historia y desarrollo del Poder Legislativo, vol. II: Vida parlamentaria y obra de Juan A. Mateos, tomo I: Historia parlamentaria de los congresos mexicanos 1812-1822, 1997, México, Miguel Ángel Porrúa, H. Congreso de la Unión.

${ }^{5}$ Loc. cit.

${ }^{6}$ Ibid. 
De la misma forma, el "espacio de discusión racional" era visto como una especie de tribunal neutral para la conformación de la opinión pública: "No hay ni puede haber otro tribunal para decidir de la opinión pública, que el tribunal de la razón y del sentido general de los hombres". Esta manera de conformar la opinión era vista como una suerte de tribunal neutral que, con las evidencias y después de contrastar los argumentos, señalaba idealmente la verdad del caso; es decir, la "verdad" se mostraba por sí misma a todo ciudadano después de una discusión racional. La opinión pública, de esta forma, se constituía dentro de lo evidentemente racional, de lo que todo hombre honrado reconocía como bueno y como malo. El error, por el contrario, expresaba una desviación de las sanas costumbres, producto o bien de una mala apreciación de las normas sociales, o bien de alguna perversión (como el egoísmo, la codicia, las pasiones que atañen a todo hombre). Pero el error solo podía afectar a los hombres individualmente considerados; nunca podía convertirse en principios socialmente compartidos. ${ }^{7}$ Por ejemplo, un escritor que firmaba con las siglas A.A.F.C. en 1821 consideraba que para escribir solo se requería la expresión de las ideas; si eran buenas o malas, útiles o inútiles, saber distinguirlas dependía del buen juicio como parte de la crítica:

Me hallo firmemente persuadido que para escribir solo se requiere expresar las ideas; ahora, si estas son buenas o malas, útiles o inútiles, como son las sentencias tantas, cuantas las cabezas; así tiene lugar la crítica, pero no hay escritor que por malo que sea que no traiga su pedazo de moral, esto es, si el asunto que el autor se propone es bueno y útil para seguirlo, y si malo e inútil para aborrecerlo y saber huir de él. ${ }^{8}$

De la misma posición todavía era Joaquín Fernández de Lizardi hacia 1823, pues pensaba que "la opinión pública, por lo común, siempre es acertada, porque como al hombre le es innato apetecer el bien y

${ }^{7}$ Palti, op cit., p. 71.

${ }^{8}$ A.A.F.C., El que se quemare que sople, 1821, México, Imprenta Americana de D. José María Betancourt, 4 p., s/n, FRBNM, Colección Lafragua, Laf.215, ficha 31. 
huir del mal, se sigue que, queriendo el bien para todos, los más lo saben distinguir y casi siempre es buena la opinión pública".

Contrapuesto a la constitución de la opinión pública surgida de una deliberación democrática racional, la conformación de la opinión pública también era pensada como la formación exclusiva de unos cuantos, especialmente de los "sabios", pues no porque la mayoría acentuara algo, significaba que estuviera en lo cierto o que pudiera dilucidar lo mejor para el cuerpo social. En diversos escritos de 1821 se llamaba al gobierno a incitar a los sabios a expresar sus ideas por medio de la prensa: "Todo gobierno debe animar a los sabios para que escriban e instruyan a la Nación; debe poner la más reflexiva atención a sus trabajos que salen de sus manos, examinándolos, adoptar las verdades que demuestran y corregir los errores en que puedan caer". ${ }^{10}$

El "sabio", el "filósofo", el "hombre de letras", era aquel cuya profesión se centraba en cultivar la razón para aumentar la de los otros. Por este motivo, el "hombre de letras" ocupaba un lugar central en la visión política de las Luces. Era la figura alrededor de la cual se organizaba la idea de política racional. El "filósofo" era percibido como el portador de la razón, de esta forma, se convertía en una especie de sacerdote secular. La opinión pública, por tanto, no se confundía entonces en lo absoluto con la voluntad general; era resultado solamente del movimiento de confrontación de las ideas entre los filósofos, de donde resultaba el descubrimiento de la evidencia. Lo que creaba a la opinión pública era una discusión filosófica, una confrontación de expertos, y no un debate democrático. ${ }^{11}$ La fuerza de esta concepción crecía ante la constante publicación de panfletos en contra de personalidades del gobierno en los que, según sus detractores, los autores no enseñaban nada bueno ni instruían a la patria, pues no tenían más mira que la personalidad, la venganza y la detracción de los ciudadanos; con un

${ }^{9}$ Joaquín Fernández de Lizardi, El hermano del perico que cantaba la victoria. Periódico político y moral (1823), en Obras, vol. 64. Citado en Palti, op. cit., p. 70.

${ }^{10}$ El Amante de su Patria, Triunfo de los escritores por la libertad de imprenta, 1821, México, Imprenta de Alejandro Valdés, 11 p., s/n., FRBNM, Colección Lafragua, Laf.442., ficha 60.

${ }^{11}$ Pierre Rosanvallon, La consagración del ciudadano. Historia del sufragio universal en Francia, 1999, México, Instituto de Investigaciones Dr. José María Luis Mora, trad. de Ana García Bergua, p. 146. 
lenguaje particularmente obsceno, no producían ninguna honra y mucho menos algún bien. Para algunos, en México todavía no se había constituido la opinión pública, puesto que la libertad de imprenta - según su consideración - no se había establecido para el hombre de saber y de literatura, sino solo para los hombres ignorantes y de mal gusto.

Lo contrario sucede cuando solo hablan los escritores sabios amigos de la libertad, y de la patria, que lejos de contemporizar con las miras ambiciosas de un gobierno arbitrario, y de fomentar las inclinaciones erróneas de las facciones populares, solo se revisten de aquella moderación que es la primera cualidad de un escritor público que trata de buscar el equilibrio de la justicia y la verdad, para contener el uno e ilustrar a los otros, sin recurrir a los medios mezquinos de la intriga, la animosidad y los libelos. $^{12}$

Estas maneras de conformar la opinión pública tenían dos cosas en común. Primero, que provenían de una discusión racional, y por ende, segundo, dejaban fuera a una parte del "pueblo", el pueblo "iletrado e ignorante", incapaz de discernir lo bueno de lo malo, lo justo de lo injusto. De esta manera, en la formación de la opinión pública, era necesario mantener alejada de la discusión a esa parte del "pueblo", denominada en los escritos como "chusma", "pueblo ignorante", "léperos", "vulgo" y otros adjetivos. Esto se debía indudablemente a la experiencia indirecta de los sucesos de la Revolución Francesa y la experiencia directa, por ejemplo, del movimiento popular de Miguel Hidalgo:

Si esto no se verifica con la prontitud y celo que exige imperiosamente el bien de una independencia que tanto ha costado a nuestros conciudadanos, después de once años de fatigas de sangre, y de privaciones inauditas, nos veremos lastimosamente en el mismo caso que la Francia, de quien dice un escritor sabio y moderado de nuestro siglo, que después que habían sufrido calamidades tan crueles como las nuestras, y cuando la opinión pública logró por fin cimentarse sobre las bases de una monarquía moderada, que se consideró como el mejor de los gobiernos para un estado de tanta extensión, estas ideas saludables desaparecieron muy en

${ }^{12}$ El Amante de su patria, Triunfo de los escritores por la libertad de imprenta., op. cit. 
breve por la osadía de los escritores atolondrados que abismaron su patria en el caos de las facciones. El partido de la Corte, dice ese gran político, que creía haber conseguido todo lo que deseaba, y por otra los partidos de los ambiciosos que esperaban sacar ventaja para sí de las turbulencias públicas, lograron por diferentes medios extraviar la opinión, ya enterrando a los escritores que proponían principios y verdades, ya animando a los partidos, ya promoviendo sediciones populares, y dándoles el nombre de voz de la nación. En este conflicto de ambiciosos, en esta fecha tumultuaria de pasiones, el hombre virtuoso enmudeció ante la fuerza, y juzgó imposible ilustrar la patria en medio de los gritos y de los puñales. Desde entonces no hubo opinión pública. Los jornaleros de los arrabales, y el cuerpo de rameras de París, fueron órgano de la voz popular. Sus gritos eran proporcionados a la cantidad de dinero que habian recibido, y el grado de ferocidad que los jefes de las facciones habian conseguido inspirarles. La masa general cansada de tantos males, y desesperada de encontrar la felicidad, suscribía a todas las alteraciones de París, semejante a un enfermo desahuciado, a quien le es indiferente la posición que ha de tener en su lecho de muerte. ${ }^{13}$ [Las cursivas son mías.]

De esta manera, para poder cumplir la expectativa de formar una opinión pública en un espacio de discusión racional — pues esto traería consigo el bien común, y la posibilidad de ser la gran nación que en ese momento, entre 1821 y 1822, las publicaciones parecían mostrar-,${ }^{14}$

${ }^{13}$ Loc. cit.

${ }^{14}$ En este periodo, se vislumbró el Imperio de Iturbide como una gran potencia americana, aliada de Gran Bretaña y con posibilidades de expansión fronteriza. Antes de que se consumara la Independencia en 1821, muchos miembros de las élites novohispanas concibieron la nueva nación como un imperio: el Imperio de la América Septentrional. México, pensaban, fue un imperio antes de la llegada de los españoles y había formado parte durante tres siglos de la Monarquía española. Mientras la Junta Provisional Gubernativa del Imperio y el Congreso esperaba que Fernando VII o algún infante de la casa Borbón aceptara el trono de México, varios proyectos imperiales, además del iturbidista, se basaron en un tipo de mesianismo político, como el de Carlos María de Bustamante y fray Servando Teresa de Mier, que pensaban en una restauración del Imperio azteca, o el de Guadalupe Victoria, que estaba a favor de que ocupara el trono del imperio un oficial criollo, siempre que estuviera casado con una india noble, o, en fin, el atribuido a Alfonso Mancilla de Teruel, conde de Moctezuma, quien conspiró con Lorenzo de Zavala para entronarse con el nombre de Moctezuma III. Este imperio debería ser una gran potencia en la América Septentrional, "el país de las delicias", "el suelo de la abundancia", "la patria de los cristianos", "el apoyo de los buenos", "el país de los racionales", "la admiración del mundo". Ya coronado, Iturbide vislumbraba la expansión del imperio de la frontera oriental 
se debía expulsar a los "escritores ignorantes" o a los portavoces de esa parte del "pueblo ignorante". Entonces, como se puede observar, en su nivel semántico-sincrónico todas estas ideas de opinión pública remitían a una visión racional ilustrada e ideal de la función que debía tener o lo que debía ser la opinión pública. Pero en su nivel semánticodiacrónico vertido por la experiencia, el concepto generaba preguntas surgidas de la práctica política. ${ }^{15}$ ¿Cómo formarla?, ¿cómo discernirla? Estas preguntas venían de tales experiencias debido al desacuerdo generado por la diversidad de pareceres.

\section{Prensa, opinión e Iturbide}

La experiencia del Imperio de Iturbide muestra esa posibilidad, pero también reconfiguró la reflexión de cómo formar la opinión pública a quiénes debían ser los dirigentes de la opinión pública. Pero antes de pasar a explicar a que nos referimos, analicemos los sucesos que llevaron

hasta la isla de Cuba, a través de Yucatán, como un paso inicial en la búsqueda de la hegemonía de México sobre el Caribe. Cfr. Rafael Rojas, "Indicios de un imaginario imperial", en La escritura de la Independencia. El surgimiento de la opinión pública en México, 2003, México, Taurus/CIDE, pp. 65-85.

${ }^{15} \mathrm{La}$ historia social y la de los conceptos se caracterizan por presuponer teóricamente, aunque de modo distinto, la relación entre sincronía y diacronía. Desde la perspectiva sociohistórica se investiga la relación entre los acontecimientos sincrónicos y las estructuras diacrónicas. Y es una relación análoga la que se da entre un discurso hablado, sincrónico, y el lenguaje ya existente, diacrónico, que ejerce una influencia constante sobre el primero, la que se tematiza desde un enfoque histórico-conceptual. Puede que todo lo que suceda sea único y nuevo, pero no hasta el punto de no haber requerido determinadas condiciones sociales previas a largo plazo que hiciesen posible ese acontecimiento único. Puede que se acuñe un concepto nuevo que en palabras plasme experiencia y expectativas antes inexistentes; pero no puede ser tan nuevo como para no estar virtualmente presente en el lenguaje dado y no recibir su sentido del contexto lingüístico del que es heredero. Por tanto, ambos enfoques de investigación incluyen en la interacción entre discurso y acción, en la que los acontecimientos tienen lugar, la dimensión diacrónica — definida de forma distinta—, sin la cual la historia no es posible ni puede comprenderse. Reinhart Koselleck, Historias de conceptos. Estudios sobre semántica y pragmática del lenguaje político y social, 2012, Madrid, Trotta, trad. de Luis Fernández Torrez, p. 19. Cfr. también Sandro Chignola y Giuseppe Duso, Historia de los conceptos y filosofía política, 2009, Madrid, Biblioteca Nueva, trad. de María José Bertomeu; Gerson Moreno Reséndiz, "Historia de las palabras (history of speech) o historia de los conceptos (Begriffsgeschichte). Qué no es la historia de los conceptos en Reinhart Koselleck", en Historia y Grafía 45 (2016), México, Universidad Iberoamericana. 
a la coronación del emperador, y para hacerlo me centraré especialmente en la reconstrucción de Torcuato S. di Tella. ${ }^{16}$

Las primeras elecciones celebradas en el México independiente, entre diciembre de 1821 y enero de 1822, confirmaron el ambiente que se vivía, pues dieron por resultado un congreso muy heterogéneo, en el que no predominaba ningún grupo. Podían distinguirse iturbidistas, iturbidistas clericales, republicanos moderados y radicales con un pasado insurgente, además de expresiones que se inclinaban hacia los intereses provinciales o regionales. El gobierno provisional no pudo imponerse porque no había una voluntad gubernamental homogénea. Por lo tanto, la difusión de impresos, como otro tipo de acciones, sería un arma fundamental para generar una percepción de popularidad alrededor de la imagen de Iturbide. ${ }^{17}$ Por ejemplo, ya anteriormente, el 7 y 8 de octubre de 1821, hubo en Puebla manifestaciones organizadas por los clérigos partidarios de coronar a Iturbide. Un anónimo panfletista que registró el acontecimiento observó que no eran los ricos ni los poderosos los que habían proclamado a Iturbide, sino los humildes. Habían llevado retratos de Iturbide y exigieron que repicaran las campanas de la catedral, lo que fue concedido por el obispo Antonio Joaquín Pérez Martínez y también por el jefe político Carlos García y Bocanegra, por lo que no podía decirse que aquel hubiera sido un motín sedicioso. ${ }^{18}$ Otro autor recordó que, mil veces, la multitud había aclamado como emperador a Iturbide y que el hecho de que esa no fuese la opinión de la gente docta no le quitaba validez. ${ }^{19}$

El apoyo populista clerical se expresó en escritos como Yo no entiendo de estas cosas, en el que las anteriores autoridades virreinales eran acusadas de haber estado a punto de destruir la religión por aplicar las

16 "El cesarismo popular", en Torcuato S. di Tella, Política nacional y popular en México, 1820-1847, 1994, México, FCE, pp. 121-149.

${ }^{17}$ J. A. M., Contestación de un americano al manifiesto del Sr. D. A. de Iturbide (11 de octubre de 1811); El derecho del pueblo mexicano para elegir emperador (1821); Derechos convincentes para elegir emperador americano (1821); El grande asunto de hoy (1821), citados en ibid., p. 121.

${ }^{18}$ Manuel María Ramírez de Arellano, Legal solicitud importantísima o salva triple de artillería imperial (1821), citado en ibid.

${ }^{19}$ E. D. L., Realizado en Puebla el importante voto de un ciudadano (1821), citado en ibid. 
medidas liberales de las Cortes españolas, con ayuda de la comunidad mercantil del Parián, enemigos de la Independencia. En la misma línea, un ironista publicó un escrito en el que alababa a Iturbide por no establecer la tolerancia religiosa o una república, además de ridiculizar algunos de los argumentos oídos en los cafés en contra del "Libertador Iturbide". También en 1821 se publicaron dos números de un Tribuno de la plebe o escritos de los pelados, redactados en un estilo popular. Decían que la plebe era la mejor parte de la sociedad, formada por "labradores, artesanos, arrieros, mineros y todos los que trabajan para mantenerse", quienes soportaban los principios impuestos y, en las mayores ciudades, habían apoyado a los ejércitos de la libertad. ${ }^{20}$

Entre sus más cercanos colaboradores en la movilización de las prensas estaba Joaquín Fernández de Lizardi, quien desde septiembre de 1821 pedía la coronación de Iturbide, a pesar del llamado a respetar los Tratados de Córdoba. ${ }^{21}$ Lizardi sería parte de ese sector de escritores, designados por Rafael Rojas como el "arquetipo del panfletista político", situado entre la masa iletrada y la alta cultura. Una de sus principales características era su trabajo a sueldo para la causa de cualquier caudillo. ${ }^{22}$ Otro de los aduladores de Iturbide fue Pablo de Villavicencio, conocido como el Payo del Rosario, que llegó a la capital en 1822 y se hizo buen amigo de Lizardi.

Por su parte, Iturbide, desde el comienzo de su campaña contra el gobierno español, es decir, desde 1820, había emprendido ciertas medidas destinadas a hacerse popular entre sus soldados y sectores más numerosos de la población. Había prometido distribuir tierras a quienes se alistaran por más de seis meses. Iturbide también trató de ganarse a los negros, especialmente a los soldados realistas de Cuernavaca y de Cuautla, entre otros, los célebres "negros de Gabriel de Yermo", que habían sido liberados por su amo solo para que lucharan en contra de la causa insurgente.

${ }^{20}$ Citados en ibid., p. 122.

${ }^{21}$ Fernández de Lizardi, Un puñado de verdades a nuestros enemigos (12 de septiembre de 1821); El Pensador Mexicano al Exmo. Sr. Gral. del Ejército Imperial D. Agustín de Iturbide (29 de septiembre de 1821), citados en ibid.

22 "Una maldición silenciada” en Rafael Rojas, op cit., pp. 169-195. 
Durante abril y mayo de 1822 se produjo la confrontación más abierta entre Iturbide y el Congreso instaurado el 24 de febrero, debido al rechazo de los Tratados de Córdoba por parte de Fernando VII y las Cortes a mediados de marzo. Días después (3 y 5 de abril) sectores de las desmovilizadas tropas españolas que aguardaban su repatriación intentaron una acción a favor de Fernando VII, pero fueron reprimidas. Esto aumentó los temores acerca de la seguridad de la independencia, y caldeó todavía más los debates en el Congreso, con escenas violentas entre Iturbide y la mayoría de la oposición, con gritos de "traidor" entre ambos bandos. Los ataques se debieron a que José Dávila, comandante del castillo de San Juan de Ulúa, que permanecía aún en poder de España, intentó convencer a Iturbide de que "no eran los diputados del Congreso mexicano los pilotos que necesitaba una nave que surca por mares desconocidos y por escollos no situados" y que su existencia política estaba en contradicción con la de las Cortes mexicanas. Con el argumento de que la vida del imperio y del propio Iturbide peligraba, Dávila le propuso, a nombre de Fernando VII, la reconquista de México con el auxilio de tropas expedicionarias españolas que iban a restablecer una "decorosa dependencia que todavía importa tenga la Nueva de la antigua España". ${ }^{23}$

Al recibir esta propuesta de autogolpe de Estado, Iturbide convocó a una sesión extraordinaria del Congreso, celebrada el 3 de abril de 1822, informó a los diputados de la inminente intervención española y solicitó al Congreso que decretase un considerable incremento del ejército imperial a su mando. Sus demandas fueron rechazadas por un grupo de diputados, a los cuales Iturbide acusó de traición, por oponerse a una ley que determinaba la suerte de la patria, mientras que ellos también lo acusaron de traición, por haber sostenido correspondencia con el comandante de San Juan de Ulúa. A partir de este momento, Iturbide reactivó su propaganda en contra del Congreso. Son de suma importancia los argumentos expresados en sus proclamas, en los que se percibe cómo la alerta defensiva en que vivía el país por la amenaza de reconquista

${ }^{23}$ Rafael Rojas, op cit., pp. 75-76. 
se transformó retóricamente en un llamado a la ofensiva militar del Imperio, en una virtual invocación de la guerra:

Ya he repetido varias veces, que la Patria peligra, que por todas partes está amenazada, que tiene enemigos dentro y fuera de sus términos, que son sus asesinos los que la adulan, queriendo persuadirla de que nada hay que temer, y que su libertad e independencia está asegurada. He dicho repetidas veces que a estos males no se les conoce otro antídoto que mantener un Ejército de treinta y cinco mil hombres, distribuido, como he dicho también, y he dicho que sin Ejército y sin Hacienda, todo lo hecho hasta ahora es perdido, y servirá sólo para ponernos en peor condición [...] Por Walis $[\mathrm{sic}]^{24}$ nos amenazan los ingleses, por Tejas se interesan nuestros vecinos, por varios puntos de la frontera Oriente las naciones bárbaras, por Guatemala la anarquía, por las Californias los rusos, por Veracruz los españoles, por las provincias la guerra civil, y por todas partes todas las naciones de Europa. ${ }^{25}$

En sus proclamas de esos meses aparece siempre su persona como la única garantía del equilibrio del país, como el único caudillo capaz de hacer de México un imperio. Así, el 15 de mayo de 1822, tres días antes de la manifestación del regimiento de Celaya que propició su coronación, envió un ultimátum al Congreso:

Si no se decreta el ejército pedido, se destina a los puntos explicados, y se sistema la hacienda muy pronto, para que el mismo ejército esté alimentado, vestido, pagado, armado y provisto de cuanto necesita, en cuyo caso respondo de la disciplina de las tropas y de la seguridad del Estado, puede procederse por quien crea tener autoridad de hacerlo a nombrar general que mande y presidente de la Regencia, pues yo doy por admitida mi renuncia en el mero hecho de no ver el remedio, o de que no se me conteste: esta renuncia la hago y verificaré mi separación de todo mando, penetrado de que es un deber no dilatarlo: es imposible que haya quien no esté íntimamente convencido de las razones en que me fundo para

${ }^{24}$ Belice.

${ }^{25}$ Papel de S. M. Imperial dirigido al Supremo Consejo de Regencia (15 de mayo de 1822), citado en ibid., p. 77. 
pedir un ejército de treinta y cinco mil hombres, y si no se decreta, es solo porque se recela de que yo lo mande". ${ }^{26}$

El 17 de mayo, el Congreso se opuso a su petición argumentando que su política de reforzamiento militar sería un camino hacia el despotismo. El 18 se desató el golpe con ayuda de suboficiales como Pío Marcha, quien reclutó hombres entre los sectores más pobres de la ciudad en el sur y sudoeste: San Pablo, La Palma, Salto del Agua y la zona cerca de la garita de San Antonio Abad (Santa Cruz Acatlán, Necatitlán, El Matadero). A la mañana siguiente, el Congreso, apresuradamente convocado a deliberar, validó la proclama de Iturbide como emperador, aun si, estrictamente hablando, no tuvo cuórum. En esa sesión, celebrada entre grupos de frailes y hombres mal vestidos que ocuparon todos los lugares disponibles, Valentín Gómez Farías, diputado por Zacatecas, desempeñó el papel principal, pidiendo que se adoptara la decisión. La medida también fue aprobada por miembros distinguidos, como Lorenzo de Zavala, de Yucatán; José María Bocanegra, de Zacatecas; y José Ignacio Esteva, de Veracruz; todos ellos futuros miembros de la logia yorkina. Además, Iturbide contó con el apoyo de Juan José Espinosa de los Monteros y Andrés Quintana Roo. ${ }^{27}$

La movilización del sector popular fue argumento de la oposición para proclamar ilegítimo al emperador. ${ }^{28} \mathrm{El}$ malestar por la coronación de Iturbide no pasó desapercibido a la mayoría de la élite mexicana no adepta de Iturbide, ya que para ellos: "la toga purpurada no bastaba para hacer del exoficial un auténtico monarca". ${ }^{29}$ Pero lo que menos podían soportar era que este criollo hubiera sido encumbrado por una turba prevaricadora dirigida por un sector de la élite adepta a Iturbide. En efecto, para esta facción de la élite política mexicana, la opinión pública

${ }^{26}$ Ibid, p. 79.

${ }^{27}$ Di Tella, op. cit., p. 128.

${ }^{28}$ Aunque la oposición se valió de los mismos medios para derribar al emperador. En las memorias de Iturbide se menciona varias veces el apoyo de que sus enemigos gozaban entre negros y castas. Cuando Santa Anna se rebeló contra el imperio, "intimidó a los pueblos cercanos de Alvarado y Antigua, y a los de color de las rancherías inmediatas”, y "puso 200 pardos a las órdenes de Victoria en el punto estratégico de Puente Nacional". Ibid., p. 133.

${ }^{29}$ Palti, op cit., p. 64. 
había sido opacada por "la gritería y los puñales" de la "chusma", había cedido su lugar a una excitada opinión llevada por las clases bajas de la sociedad mexicana, y para colmo le dieron el nombre de "opinión nacional". La oposición a Iturbide argumentó que "la chusma" fue justamente la que se hizo presente en la elevación del emperador, no la razón. Esta parte de la nueva élite mexicana asoció a las clases bajas con el sector adicto a Iturbide, por ello su gobierno no podía ni debía tener legitimidad, pues no provenía de la opinión pública.

Los enemigos de Iturbide señalaron después de su deposición los aspectos populares de su apoyo. El panfletista liberal Rafael Dávila dividió

al pueblo común, al que aún le gusta ver a Iturbide en el trono, en dos clases: una que no se deja convencer por argumentos, que después de haber escuchado a muchos y muy convincentes sólo responde: [...] si era malo, por qué lo proclamaron emperador. Si no mató muchas vidas fue porque no quiso hacerlo y porque era un santo, entonces por qué los que hoy hablan contra él no abrieron la boca cuando estaba en el trono; con esta clase de hombres yo no hablo porque actúan como irracionales, solo por instinto; hablo con quienes dan lugar a la razón y pueden ser convencidos por la verdad. ${ }^{30}$

El mismo autor continuó analizando así la contraposición de intereses; "sólo la mayor parte de la clase media y un pequeño número de los otros estamentos aspira a la libertad; [Iturbide] se asoció con los más ambiciosos de la clase superior y media y con los más viles de las inferiores". ${ }^{31}$ De la misma forma, el autor de Muerte y entierro de Agustín Primero (1823) incluyó entre los deudos dolientes a un gran número de clérigos, viejas, monjes, fanáticos, multitudes con una vela en la mano izquierda y una navaja en la derecha, y "muchos leperillos, con veleta, al son de un tambor, pero en vez de armas, llevando cañaverales con rotulones", refiriéndose al hábito de aquellos días de llevar estandartes en las manifestaciones públicas. Entre otros, en esa imaginaria

${ }^{30}$ Rafael Dávila, Sea Iturbide al descubierto (1823), citado en Di Tella, op cit., p. 133.

${ }^{31}$ Loc. cit. 
procesión iban "un religioso mercedario, rodeado de algunos leperuscos". Sin duda, dice Di Tella, iba el padre Aguilar del convento de la Merced, calificado por Carlos María de Bustamante como "jefe de los demagogos" y que fue coronel del batallón de milicias reclutado por Iturbide entre los barrios bajos hacia el final de su régimen. El escritor descubrió también entre la procesión a los hermanos Mariano y Manuel Barreda, coroneles por aquel tiempo, que habían lucrado haciendo uniformes para el Ejército Trigarante y que después obtuvieron la concesión de recoger la basura de la ciudad. Se encontraban entre los principales jefes de la improvisada milicia otros personajes, como Luciano Castrejón, más conocido como el Marqués del Bodegón, Pío Marcha y sus sargentos, y otros varios improvisados coroneles. ${ }^{32}$

Al final de su gobierno, ante la revuelta encabezada por Antonio López de Santa Anna, a la que se sumaron Guadalupe Victoria, Vicente Guerrero y Nicolás Bravo, y cuando todo estaba perdido para el emperador, Joaquín Fernández de Lizardi le pidió a Iturbide que renunciara a la corona para su mayor gloria, y al mismo tiempo dilucidó cuál era la verdadera opinión pública que debía escuchar para sostenerse en el trono.

Es verdad que no le faltarán aduladores como siempre; pero estos serían algunos nobles, o frailes y vulgares de la última plebe, cuyos vivas y sufragios son alucinantes, pero de ningún valor. Mr. de Pradt dice que en 1814 en el Congreso de Viena el Lord Wellington sostuvo a su presencia que Fernando VII con sus frailes y populacho tenía lo más fuerte de la nación. Los hechos posteriores manifestaron su equivocación, y tales sujetos son un apoyo ridículo. En el estado medio consiste la fuerza física y moral; si con esta no cuenta S. M. el abdicar a la corona será su mayor gloria, porque acabará por manifestar que nada aprecia más que el bien de la patria. ${ }^{33}$

${ }^{32}$ Ibid., p. 134.

${ }^{33}$ El Pensador Mexicano, Por la salud de la patria se desprecia una corona, 1823, México, imprenta del autor, 8 p., FRBNM, Colección Lafragua, Laf.258, ficha 3. 


\section{Quiénes forman la opinión pública}

A partir de los acontecimientos que llevaron al trono a Iturbide, el problema de la opinión pública tenía que sufrir una restructuración, que se produjo ya en la etapa republicana, en agosto de 1825. En el periódico $\mathrm{El} \mathrm{Sol} \mathrm{apareció} \mathrm{una} \mathrm{serie} \mathrm{de} \mathrm{artículos} \mathrm{con} \mathrm{el} \mathrm{título} \mathrm{"Ensayo} \mathrm{sobre}$ la opinión pública" ${ }^{34}$ que, curiosamente, se repitieron íntegramente el 2 de enero de 1828 en las páginas del Observador de la República Mexicana, como "Discurso sobre el modo de formarse la opinión pública". ${ }^{35}$ Los escritos giraban en torno a la pregunta sobre cómo se formaba la opinión pública. La importancia de dar una respuesta radicaba en el peso trascendental de la opinión pública como sostén de la soberanía: "Si no queremos pues, fluctuar continuamente entre la anarquía y el despotismo, es necesario formar un lazo que una estos dos extremos, cuya oposición es solo aparente, y este lazo no puede ser otro sino la opinión pública". ${ }^{36}$ Así, a nivel sincrónico, el concepto de opinión pública no sufrió ningún cambio en su acepción semántica, pues se seguía concibiendo como "la voz general de todo un pueblo convencido de una verdad, que ha examinado por medio de la discusión". ${ }^{37}$ Cimentada por la reunión, "que es el origen de la fuerza", entonces, en vano se opondrían los intereses y miras particulares a la voluntad de todos; en la "voluntad de todos" estaría encerrada la "verdadera opinión". Sin embargo, a nivel de la diacronía vertida por los sucesos ocurridos en la corta vida independiente, era claro que el concepto se confundía con una "falsa opinión", esgrimida por ambiciones particulares.

Ninguna medida que no sea de interés común, próxima y fácilmente perceptible, es objeto adecuado de la verdadera opinión pública [...] Esta

${ }^{34}$ El Sol, ediciones del 3 de agosto de 1825, núm. 781, pp. 199-200; 4 de agosto de 1825, núm. 782, pp. 202-204; 9 de agosto de 1825, núm. 788, pp. 223-224; 11 de agosto de 1825 , núm. 789, pp. 231-232; 12 de agosto de 1825, núm. 790, pp. 234-235.

${ }^{35}$ Decimos “curiosamente", porque el artículo es atribuido por Palti a José María Luis Mora. Aunque no es una imposibilidad la autoría de Mora, los editores de El Sol aclaran la fuente de los artículos publicados en su periódico: "Este excelente artículo, aunque tomado del Español Constitucional escrito para España, es tan adaptable a nuestras circunstancias que hemos creído deberlo insertar sin variación alguna. - Los E.E." El Sol 12 de agosto de 1825, núm. 790, pp. 234-235.

${ }^{36}$ El Sol, 3 de agosto de 1825, núm. 781, pp. 199-200.

${ }^{37}$ Loc. cit. 
regla segura nos debe servir para dar su justo valor a esas oleadas populares y tumultuarias, principios de las revoluciones y obra exclusiva de los ambiciosos demagogos: ellas nunca serán signo de la opinión pública y de la voluntad general, porque entre otras cualidades les faltará la estabilidad y firmeza; serán pensamientos y deseos momentáneos, casi siempre sugeridos por los perversos, pero no serán el deseo público. Una multitud excitada y fascinada aplaudirá en Roma la muerte de los Gracos; llevará en París a la guillotina a los hombres más ilustres y virtuosos; pedirá en México la elevación al trono de un caudillo pero ninguna de estas cosas serán efecto de la opinión pública, sino el 'eco de la seducción, el grito de pillos y rameras que subirá más alto, según se explica un periodista célebre, cuanto mejor lo hayan pagado los corifeos de los partidos' [...] Distinguimos, pues, cuidadosamente la voz popular de la opinión pública. La primera se forma con la misma facilidad que las nubes de primavera; pero con la misma se disipa. Es producida por el terror, por las facciones, por la ignorancia, por otras mil causas accidentales que pueden ser destruidas por sus opuestas. ${ }^{38}$ [Las cursivas son mías.]

Para evitar esta confusión en lo siguiente, los editores de El Sol partieron del mismo lugar que sostenía Zavala en El Hispano-Americano Constitucional, sobre el que hicimos referencia más arriba, y continúa El Sol diciendo que

no hay magistratura alguna que pueda obligarme a adoptar un principio de que no está convencida mi razón [...] No hay, pues, ni puede haber otro tribunal para decidir sobre materias de opinión pública, sino el tribunal de la razón y del sentido general de los hombres, cuando por la libre discusión y la ruina de los intereses de partidos se hallan en estado de juzgar sanamente. ${ }^{39}$

No obstante, la mayor parte de los ciudadanos, “ocupados en sus obligaciones domésticas, si bien son capaces de conocer la verdad cuando se les presenta con claridad y exactitud — no lo son de proponer

${ }^{38}$ Loc cit.; véase también El Observador de la República Mexicana, $1^{\circ}$ de agosto de 1827 , núm. 10, pp. 255-284.

${ }^{39}$ El Sol, 4 de agosto de 1825, núm. 782, pp. 202-204. 
ideas políticas, porque ni han hecho el estudio necesario para adquirirlas, ni tienen el hábito de ordenarlas".

Solamente los que se han entregado al estudio de las letras, tienen el caudal necesario de ideas y conocen el método de exponerlas [...] Los sabios, pues, deben ser el primer órgano de la opinión pública: esta es la primera y más sagrada de sus obligaciones: ellos ejercen la magistratura de la enseñanza [...] Todo gobierno debe animar a los sabios para que escriban e instruyan la nación: debe poner la más reflexiva atención a los trabajos que salen de sus manos, examinarlos, adoptar las verdades que demuestran y corregir los errores en que puedan caer. ${ }^{40}$

El punto de partida ayuda a reformular el concepto de opinión pública. Solo la discusión racional puede formar opinión pública; sin embargo, no todos los habitantes están instruidos para adentrarse en esa discusión. ¿Quiénes son estos virtuosos con el tiempo y capital necesario para la instrucción de ellos y su familia? Los propietarios, contesta sin dudar El Sol:

[A]prender, pues, naciones que queréis ser libres: formad un partido nacional, y haced que este partido se componga del todo de todos los ciudadanos útiles: de esta masa general de propietarios, de este pueblo instruido o que puede instruirse, en el cual es imposible suponer miras de ambición, miras funestas al bien público: porque su bienestar individual es el interés mismo de la patria. ${ }^{41}$

De esta forma, la pregunta sobre el cómo se transforma en la pregunta por los quiénes sustentan la opinión pública. El problema ya no radicaba en la manera de formarla, problema cabalmente resuelto, sino en cómo generar una operación de inclusión y al mismo tiempo expulsión del espacio público: inclusión en el sentido de unificar esa parte industriosa y propietaria del país, y expulsión en el sentido de sacar a esa "turba de escritores de mediana instrucción" que habían invadido una profesión solamente reservada a los "ciudadanos útiles". En esta

${ }^{40}$ Loc. cit.

${ }^{41}$ Ibid. 
operación — que radicalizó el enfrentamiento entre las facciones — se sustentaron los diferentes grupos para la formación de una opinión pública "verdadera". Circulantes dentro del espacio público, buscaron elevarlas como sustentadoras de la "verdad" y, lógicamente, los portadores de todas ellas se justificaron como portadores de la opinión pública.

Tras la polarización de la vida política mexicana entre 1826 y 1828 , la experiencia apuntaba, para algunos, a una pérdida de las expectativas centradas en la opinión pública; es decir, el optimismo puesto en la opinión pública como sustentadora de la "verdad" se fue perdiendo, al grado de que ciertos grupos plantearon la posibilidad de ceder la responsabilidad a un tercero que propiciara el espacio adecuado para la formación de la opinión pública. Sin embargo, no se perdió la finalidad ideal de la opinión pública, que había que aprovechar para la ilustración de la nación, aportar conocimientos útiles, llamar la atención a las autoridades que por ser hombres también podían equivocarse, pero sin caer en los excesos de los libelos infamatorios y atacar constantemente las bases constitucionales, la religión y la moral.

Más tarde, hacia mediados del siglo XIX, sostener la soberanía de la República en la opinión pública sería tomado como un imposible. Así lo manifestaba El Siglo XIX hacia 1848:

Al terminar la invasión norteamericana, cada clase y aun cada individuo ha formado una fracción; nunca las opciones habían sido tan numerosas, tan extremadas, se nos propone desde entregarnos a los extraños, hasta a la voluntad de un solo hombre; y cualquiera resolución de estas que se tomara, no solo sufriría grandes disputas de sus autores, sino que quedaría reducida a ser la voluntad de unos pocos. ${ }^{42}$

A mediados del siglo, para autores como Ignacio Ramírez el sustento de la legitimidad en una opinión pública era una ficción. No había para él una "opinión pública verdadera"; lo único que se observaba en la realidad — decía—, es que había opiniones diversas y contrarias. Siendo esto así: ¿se debería respetar la opinión pública? ¿Cuál de tantas debería respetarse? Por estas ideas, en 1849 El Universal consideraba

${ }^{42}$ Citado en Palti, op cit., p. 219. 
insostenible la idea del origen por medio de un acuerdo y contrato de la sociedad. Para 1851, esta pluralidad se expresó en una proliferación de candidatos a la presidencia. Cada periódico representante de alguna facción tenía el suyo, y ninguno obtendría por claras razones la mayoría. Los más importantes eran Nicolás Bravo, Juan Almonte, Manuel Gómez Pedraza, Luis de la Rosa y Mariano Arista, apoyados por El Universal, La Linterna de Diógenes, El Siglo XIX, El Demócrata y El Monitor Republicano, respectivamente. ${ }^{43}$

\section{Conclusiones}

La apertura del espacio público en los inicios de la vida independiente fue totalmente revolucionaria para la sociedad mexicana de la época, pues el establecimiento de la libertad de imprenta facilitó la circulación de periódicos en los que cualquier persona podía dar su opinión acerca de los asuntos de interés público. Sin embargo, muchos individuos mostraron su inconformidad por la amplia circulación de impresos que consideraban de "mal gusto", "groseros" y "vulgares". Muchos se dieron a la tarea de explicar qué era la opinión pública, qué se debía entender como opinión pública, cómo se formaba y quiénes se encargaban de formarla. El objetivo era generar un mecanismo de distinción que ayudara a discernir entre la "opinión pública verdadera" y la "opinión común y falsa".

Estas preocupaciones no eran banales, pues en el concepto opinión pública se trató de sustentar la legitimidad política y la soberanía de la nación mediante lo que concebían como espíritu público o voluntad general. De esta forma, la opinión pública era entendida como la reunión de las voluntades particulares que en pública discusión sobre los problemas que atañían al común diera las pautas para que la voluntad de la mayoría, la opinión general, la voluntad de todos, emergiera como la opinión pública. Sin embargo, después de las experiencias acumuladas y los caóticos acontecimientos que llevaron al trono a Agustín I,

${ }^{43}$ Palti, op. cit., especialmente el apartado "Los límites de la legalidad y el escape de lo trascendente", pp. 235-251. 
el problema de la opinión pública tendría que sufrir una restructuración. La pregunta sobre el cómo se transformó en la pregunta por quiénes sustentarían la opinión pública. El problema ya no radicaba en la manera de formarla, problema cabalmente resuelto, sino en cómo generar una operación de inclusión y al mismo tiempo expulsión del espacio público para la constitución de esa opinión.

Finalmente, la reflexión sobre el concepto de opinión pública nos llevó a un lugar que se encuentra más allá del significado del concepto. En su carácter semántico-sincrónico, es decir pragmático, generalmente va referido a una "verdad" surgida de una discusión pública; de esa forma, permitiría abrigar expectativas referidas a un posible estado de cosas futuras. Pero en su carácter existencial-diacrónico y polémico, el concepto conllevaba, en su sedimentación conceptual, preguntas y estados de cosas, además de ánimos generados por las experiencias recientes de la práctica política. ¿Cómo formar la opinión pública? ¿Cómo discernirla? ¿Quiénes están facultados para formar la opinión pública? Estas preguntas surgieron de tales experiencias. A mediados del siglo XIX, el concepto de opinión pública dejó de tener relevancia conceptual y política, y esto se evidencia en lo ilógico que resultaba para algunos tratar de sustentar la soberanía en una opinión pública "mítica". 


\section{DE LOS PELIGROS \\ DE LA CREDULIDAD \\ ACRÍTICA EN \\ TIEMPOS DE \\ MERCADO ESPIRITUAL \\ María Teresa López Fernández*}

RESUMEN: En una época caracterizada por el derrumbamiento de los referentes tradicionales, el debilitamiento de las religiones institucionalizadas y la aniquilación de los sentidos fuertes de los conceptos de verdad y bien, surgen los llamados movimientos de la Nueva Era como alternativa para la necesidad de sostén y sentido del hombre contemporáneo. La reivindicación del pensamiento crítico se torna urgente como principal salvaguarda individual y colectiva frente a lo que pudiera tratarse, en algunos casos, de fenómenos de mercado, consumo y charlatanería espiritual.

$$
\text { গoes }
$$

THE DANGERS OF UNCRITICAL CREDULITY

IN TIMES OF A SPIRITUAL MARKET

ABSTRACT: In an era characterized by the fall of traditional references, the weakening of institutionalized religions and the destruction of the absolute senses of truth and good, emerge New Age movements, an alternative to the need of support and meaning to the contemporary man. It becomes urgent to revindicate critical thinking as the main individual and collective safeguard to the spiritual quackery, mercantilism, and consumerism phenomena.

PALABRAS CLAVE: pensamiento crítico, Nueva Era, espiritualidad, posmodernidad, mercado. KEY WORDS: critical thinking, New Age, spirituality, postmodernity, market.

RECEPCIÓN: 21 de febrero de 2016.

APROBACIÓN: 26 de agosto de 2016.

* Departamento Académico de Estudios Generales, ITAM. 
CITAM Derechos Reservados.

La reproducción total o parcial de este artículo se podrá hacer si el ITAM otorga la autorización previamente por escrito. 


\title{
DE LOS PELIGROS DE LA CREDULIDAD ACRÍTICA EN TIEMPOS DE MERCADO ESPIRITUAL
}

\author{
Hemos de evitar, es cierto, que el alma, \\ cuando cree lo que no ve, se finja algo irreal \\ y espere y ame lo que es falso.
}

Agustín DE HiPONA ${ }^{1}$

El proceso moderno de secularización -impulsado con mayor claridad a partir del siglo XVII - tuvo un efecto en la visión del mundo occidental, en particular en lo referente a la religiosidad como forma fundamental de explicación de la realidad y de delimitación moral de la conducta humana. Sobre las implicaciones de este proceso, Sánchez Carrión apunta:

Bajo la óptica multidimensional, secularización significa primeramente un proceso de laicización que implica que la religión pasa a ser una institución más entre otras muchas, ya sin la pretensión de ser globalizante. [...] En segundo lugar, la secularización significa una alteración en la participación religiosa, que se refiere al grado de compromiso de los individuos con las instituciones religiosas. El cambio religioso es el tercer elemento de este enfoque y hace referencia al cambio de postura de las instituciones religiosas en cuestiones de creencias, moralidad y rituales, que supone el surgimiento y descenso de los diversos grupos religiosos. ${ }^{2}$

${ }^{1}$ San Agustín, Tratado sobre la Santísima Trinidad, 1956, Madrid, Biblioteca de Autores Cristianos, trad. de Luis Arias, p. 511.

${ }^{2}$ Miguel Ángel Sánchez Carrión, La Nueva Era: ¿Sacralización de lo profano o profanación de lo sagrado?, 1999, México, IBERO-ITESO, pp. 24 y 25. 
Con el advenimiento de la secularizada era moderna, el hombre, específicamente el individuo, se erige como valor absoluto y criterio último para definir, para y por sí mismo, a través de sus propias facultades sensibles y racionales, los propios parámetros epistémicos y éticos. Lejos de supuestos dictados divinos o normativas eclesiásticas, pero también de una emancipada permisividad, está recién conquistada autonomía exalta el deber de la obligación moral por una intrínseca exigencia racional, apuntada con considerable optimismo hacia la perfectibilidad del género humano y el progreso de la civilización. La Ilustración consolida así una nueva fe en la rigurosidad del conocimiento científico y filosófico como cimientos ciertos y seguros para una alcanzable universalidad de la verdad y la bondad, constreñidas a la medida del hombre en su condición de sujeto.

Esta confianza básica en las capacidades humanas y en su potencial ilimitado para el progreso fue puesta en tela de juicio hacia 1950, tras la bomba atómica, los holocaustos y la destrucción de Europa, testimonios de las innegables posibilidades destructivas de la razón y del conocimiento científico y tecnológico. En consecuencia, en las décadas de 1960 y 1970 amplios sectores sociales hicieron un frente contestatario para oponerse a los cimientos mismos de la época moderna. Se sentaron entonces las bases para la transformación posmoderna occidental que, en la década de 1980, emprendió la fluida travesía cultural por nuevas pistas, claves o modelos que, sin pretensiones de Verdad (con mayúscula), universalidad o atemporalidad, pudieran brindar orientación transitoria al accionar del ahora desamparado hombre, vacío de Dios y de sí mismo.

La posmodernidad se caracteriza por la flexibilización y el uso extensivo de eufemismos, la relativización y la inmediatez. Frente a cualquier forma de exigencia categórica se privilegia la subjetividad a la carta, la vida libre, la satisfacción inmediata del deseo, la estimulación de los sentidos, la comodidad consumista y el bienestar individual. La moral adquiere, en términos de Lipovetsky, la cualidad de indolora, en medio de una especie de minimalismo ético preocupado más por los límites de lo no permitido que por la afirmación positiva del deber. ${ }^{3}$ El individuo

${ }^{3}$ Cfr. Gilles Lipovetsky, El crepúsculo del deber: La ética indolora de los nuevos tiempos democráticos, 2012, Barcelona, Anagrama, trad. de Juana Bignozzi, pp. 46-57. 
asume, a partir de aquí, su autoconstrucción personalizada en un movimiento de reciclaje permanente orientado por un referente único: el demandante Narciso y su hambre insaciable de felicidad light. El sentido de lo comunitario se debilita y sus elementos relacionales de identidad y cohesión se reducen a una mínima superficie; las instituciones tradicionales pierden su poder social de determinación y el individuo es dejado a su propia suerte de consumidor capitalista, esto es, al libre arbitrio de su capacidad de elección en cada uno de los ámbitos de la existencia, sujetos ahora con exclusividad a la ciega lógica del mercado. Como afirma Lipovetsky,

es el proceso de personalización lo que ha permitido esa distensión cool de las referencias sociales, la legitimación de todos los modos de vida, la conquista de la identidad personal, el derecho de ser absolutamente uno mismo, el apetito de personalidad hasta su término narcisista. ${ }^{4}$

Esta nueva forma de narcisismo, libre de culpas morales, se abre sin ambages a la asunción de los contrarios e, incluso, a su coexistencia pacífica y simultánea en un mismo individuo. Así, es posible, por poner un ejemplo, ser cristiano y creer en la reencarnación.

Como parte del plural y personalizado menú, la posmodernidad trae consigo un proceso de desecularización contrapuesto al que, como hemos visto, fue uno de los rasgos más distintivos de la modernidad: el rechazo del paradigma religioso en pos de la exaltación de la razón y la ciencia como vehículos privilegiados para la explicación válida y verdadera del mundo. En este contexto, frente al modelo mecanicistapositivista de explicación causal de la realidad, se produce la vuelta a la espiritualidad como fuente de significación, si bien en unos términos peculiares y nuevos, radicalmente distintos a las formas religiosas de la erosionada tradición. La desecularización promueve, para ello, el revestimiento de una realidad anteriormente desencantada a través de una pretendida sacralización del mundo de lo profano, en un intento por recuperar el sentido de lo mágico y lo divino: "La atracción de lo

${ }^{4}$ Gilles Lipovetsky, La era del vacio: Ensayos sobre el individualismo contemporáneo, 2000, Barcelona, Anagrama, trad. de Joan Vinyoli y Michèle Pendanx, p. 109. 
religioso es inseparable de la desubstancialización narcisista, del individuo flexible en busca de sí mismo, sin referencias ni certeza - aunque fuera la del poder de la ciencia". ${ }^{5}$ Esta nueva religiosidad queda claramente plasmada en el movimiento de la Nueva Era, el cual, lejos de ser monolítico u homogéneo, engloba una amplia cantidad de escuelas, métodos, técnicas, filosofías de vida y terapéuticas, que comparten ciertos rasgos básicos comunes y una actitud "a la carta" frente a la realidad y el ámbito de lo espiritual.

En este contexto, el momento presente clama por el fortalecimiento del pensamiento crítico como ejercicio individual y colectivo generalizado, en una coyuntura en la cual la experiencia de la posmodernidad lanza al individuo al vértigo del vacío de referentes y normas incuestionables, condición aprovechada por algunas formas espurias de espiritualidad trastocadas por intereses mercantilistas que falazmente pretenden satisfacer una sed viva de sentido. Para esta recuperación de la criticidad, se hace necesaria la mediación entre la radicalidad del objetivismo, que subestima la construcción subjetiva de signos y símbolos y su constitución en realidades humanas, y del subjetivismo, el cual absolutiza la capacidad creadora del sujeto con el simple recurso de sus deseos e intenciones, hasta negar la existencia y los límites de la realidad objetiva. La primera sería la actitud cientificista, y la última, la propia de la espiritualidad de la Nueva Era. El enfrentamiento entre ambas actitudes constituye, curiosamente, una de las reediciones contemporáneas del viejo problema de la relación entre la razón y la fe.

No es aquí nuestra intención juzgar — ni mucho menos prejuzgarsobre la autenticidad o artificio, valor o futilidad, de ninguno de los movimientos adscritos a la Nueva Era. Se trata únicamente de mostrar la importancia de robustecer el pensamiento crítico para generar criterios mínimos de valoración y discriminación y evitar, así, que el vacío y la sed de sentido nos hagan presas fáciles en lo individual y en lo colectivo de charlatanes ávidos de negociar en el nuevo mercado de la espiritualidad. Los criterios en sí mismos deberán ser objeto de un estudio aparte; en este caso, nos abocaremos únicamente a defender su posi-

${ }^{5}$ Ibid., p. 118. 
bilidad como resultado del ejercicio responsable y pertinente del examen racional. Cabe señalar que al hablar de la razón, nos referiremos en lo fundamental al ejercicio crítico de pensamiento que integra experiencia y lógica, y no a la absolutización racionalista que encumbra a la facultad racional como vía exclusiva o privilegiada de conocimiento.

Procederemos pues, a continuación, a describir brevemente la Nueva Era para, posteriormente, señalar algunos de sus peligros y subrayar, por último, la necesidad de fortalecer el pensamiento crítico.

\section{La espiritualidad posmoderna de la Nueva Era}

La primera dificultad al intentar conocer y describir la así llamada Nueva Era es la vaguedad, imprecisión y ambigüedad conceptual con las que opera. El movimiento se caracteriza por un eclecticismo que integra, no necesariamente de manera coherente, filosofías y religiosidades occidentales y orientales provenientes de muy diversas tradiciones, y se expresa en muy diversas escuelas, métodos o técnicas y movimientos espirituales que comparten, sin embargo, los elementos básicos comunes constitutivos del gran marco de la Nueva Era.

A partir de un peculiar sentido de lo místico que se coloca más allá de cualquier doctrina o dogma particular, esta especie de paradigma niega la preeminencia de las explicaciones mecánico-causales del mundo, propias de la ciencia moderna, para concedérsela a la idea de que los fenómenos son en verdad producidos por la manifestación de una conciencia universal vaga, indefinida, que toma el lugar vacante de la divinidad posmoderna. En contra de la fragmentación y la especialización cientificistas, el misticismo de la Nueva Era concibe la realidad como un todo integrado holísticamente, al cual aspira y se dirige. Donde la mente lógica lineal encuentra dualidad, antítesis, causa y efecto, la actitud mística predominantemente intuitiva descubre, en la profundidad subyacente y por debajo de la separación superficial e ilusoria, pura y auténtica unidad.

Aun cuando los orígenes de la Nueva Era sean poco claros debido a su desestructurado eclecticismo, el antecedente principal puede ser ubi- 
cado en la Sociedad Teosófica, fundada por Helena Petrovna Blavatsky en 1875 con el objetivo de desentrañar la verdad común a todas las religiones y sabidurías de la humanidad y conformar una nueva y única religión mundial. La expresión "Nueva Era" fue acuñada por la inglesa Alice Anne Bailey (1880-1949), que había sido integrante de dicha sociedad. ${ }^{6}$ Más adelante, los movimientos contraculturales de la década de 1960 contribuyeron a delinear esta forma de espiritualidad, que se consolidó en la década de 1980 .

De acuerdo con sus seguidores (entre los cuales predominan en la actualidad los occidentales urbanos de un estrato socioeconómico medio o alto), nos encontramos al inicio de una nueva etapa, la Nueva Era o Era de Acuario, en la cual el paradigma racionalista, institucionalizado, rígido y belicoso, propio de la pasada era de Piscis, será transformado a partir de una mayor sensibilidad y expansión de la conciencia humana, abierta ya a la captación de las manifestaciones de la energía divina y preparada para alcanzar la armonía y el entendimiento pleno entre los hombres. En la teoría, su cuerpo doctrinal milenarista incluye y mezcla esoterismo, magia, hechicería y chamanismo, espiritismo, religiones antiguas y paganas, gnosticismo, cristianismo, hinduismo, jainismo, budismo, taoísmo, confucionismo, satanismo, astrología y ecologismo. Pretende fundamentarse sobre versiones propias de temas científicos, en particular de la física cuántica, y ha desarrollado una completa industria en la literatura, el cine y la música que ha logrado penetrar, sutil y subrepticiamente en amplios sectores de la cultura popular contemporánea. ${ }^{7}$

La Nueva Era se asocia también al enfoque de la psicología llamado transpersonal, surgido en la década de 1960, el cual postula que el ego individual es ilusorio y, por tanto, la meta del crecimiento y la realización personal deberá consistir en expandir las fronteras egoicas hasta la final integración en la unidad del todo. ${ }^{8}$ Algunos de los movimientos de la Nueva Era recuperan además ciertos elementos de los saberes y prácticas tradicionales de los pueblos originarios, como es el caso de la utilización de sustancias propias de las prácticas espirituales

${ }^{6}$ Cfr. Sánchez Carrión, op. cit., pp. 33 y 34.

${ }^{7}$ Ibid., pp. 34 y 35 .

${ }^{8} \mathrm{Cfr}$. Ken Wilber, La conciencia sin fronteras: Aproximaciones de Oriente y Occidente al crecimiento personal, 2006, Barcelona, Kairós. 
indígenas y rurales tales como la ayahuasca, ${ }^{9}$ el peyote y los hongos alucinógenos.

En cuanto a su fundamentación científica (o seudocientífica), la Nueva Era defiende lo que considera un nuevo paradigma más allá de los rígidos límites de la ciencia tradicional identificada con la física newtoniana. A partir de algunos elementos de la física cuántica, los defensores de esta "nueva ciencia" conciben el universo de tal modo, holísticamente, que física y mística entrecruzan sus fronteras difusamente: ${ }^{10}$ la Tierra es vista como un gran organismo y reinterpretada en los términos de la antigua diosa Madre Naturaleza o Gaia. ${ }^{11} \mathrm{Al}$ interpretar la realidad en su conjunto en términos de energía, las diferencias ontológicas se reducen a meras vibraciones energéticas de frecuencia distinta, con lo cual cobran sentido expresiones hoy populares del tipo "todos somos Uno". En esta dirección, Dios no es más que la energía y las leyes que la gobiernan, de donde se deduce el carácter divino de todo lo existente, incluido, desde luego, el hombre. ${ }^{12}$ En esta especie de panteísmo o de disolución idealista de la individualidad, el Método Pathwork $^{13}$ afirma, por ejemplo, lo siguiente:

El Ser Superior es nuestra encarnación personal del espíritu universal que se mueve a través de todas las cosas y nuestra conexión con él [...] Es un continuo que empieza en el nivel del ego y se amplía, se profundiza y se expande hacia los niveles transpersonales de la conciencia y hacia la experiencia de unidad con Dios. ${ }^{14}$

La divinidad no es concebida, pues, en términos personales, sino como fuente y sustrato ontológico universal, entendido como energía e

${ }^{9}$ Para un primer acercamiento al fenómeno reciente del auge de la ayahuasca en el mundo occidental, puede consultarse el documental Ayahuasca: Vine of the soul (2010), de Richard Meech.

${ }^{10} \mathrm{Cfr}$. Sergej Flere y Andrej Kirbiš, "New Age, religiosity, and traditionalism: A crosscultural comparison", Journal for the Scientific Study of Religion, vol. 48/1 (2009), pp. 161-184.

${ }^{11} C f$ r. Sánchez Carrión, op. cit., pp. 32 y 42-44.

${ }^{12}$ Cfr. Ibid., p. 48.

${ }^{13}$ Método de desarrollo personal y espiritual creado por la austriaca Eva Pierrakos (1915-1979), quien entre 1955 y 1979 transmitió en Estados Unidos, por supuesta canalización, una serie de conferencias dictadas por una entidad espiritual llamada el Guía.

${ }^{14}$ Susan Thesenga, Vivir sin máscaras: Método Pathwork para enfrentar los patrones destructivos que limitan tu realización personal, 2012, México, Pax, trad. de Víctor Becerril Montekio, pp. 255 y 256. 
identificado vagamente con el amor. En el ser humano habita la "chispa divina" (postulada ya por los paganos en la antigüedad) y en ella se halla su más profunda y auténtica identidad, la cual se expresa a través de la personalidad individual compuesta de un alma y de un cuerpo mental, emocional y físico. Dada la divinidad esencial de cada uno, la intuición -íntimamente ligada a la experiencia emocional—, la "voz interior" o "el corazón", se convierten en los criterios fundamentales para dar sentido y guiar la acción y el desarrollo personal, el cual consiste en el progresivo descubrimiento de la identidad real divina que yace en lo profundo del yo. ${ }^{15}$ La creencia en la reencarnación propia de las religiones orientales es recuperada en el planteamiento de que el hombre experimenta individualmente el proceso de aprendizaje y expansión espiral de la conciencia a través de sucesivas vidas: ${ }^{16}$ "Solo después de haber superado sus involucramientos negativos, el hombre concluirá el ciclo de vidas en esta esfera y su desarrollo continuará entonces en otras esferas de vida, que ofrecerán nuevas condiciones compatibles con su nuevo estado". ${ }^{17}$

El poder de la intención subjetiva es exacerbado hasta el punto de considerar la realidad un producto de la creación de la conciencia. Expresiones populares y comunes en los medios de comunicación como "decretar" la felicidad, la abundancia económica, la paz, etc., obedecen a esta creencia. El pensamiento es capaz de crear, por sí mismo, salud o enfermedad, paz o guerra, prosperidad o pobreza, según se orienten sus intenciones hacia la positividad o la negatividad: "Si repites algo suficientes veces lo conviertes en una 'realidad', y si tu pensamiento está en una onda Theta lo suficientemente profunda, es posible hacer que se materialice instantáneamente en la realidad". ${ }^{18}$

${ }^{15} \mathrm{Cfr}$. Dick Houtman y Stef Aupers, "The spiritual turn and the decline of tradition: The spread of post-Christian spirituality in 14 Western countries, 1981-2000", Journal for the Scientific Study of Religion, vol. 46/3 (2007), pp. 305-320.

${ }^{16}$ Cfr. Sánchez Carrión, op. cit., p. 62.

${ }^{17}$ Eva Broch Pierrakos, "La dualidad a través de la ilusión: transferencia”, Fundación del Pathwork, México, en <http://www.pathworkmexico.org/sitio/downloads/conf_118_m.pdf>, consultado el 9 de julio de 2015.

${ }^{18}$ Renata Braun y Antonio Sánchez-Muñiz, “¿Qué es ThetaHealing®?”, Theta Healing México, en $<$ http://www.thetahealingmexico.com/ThetaHealing.htm>, consultado el 19 de julio de 2015 . 
Gil y Nistal, estudiosos de esta nueva forma de religiosidad, afirman:

Así, la NA [Nueva Era] puede definirse como: la propuesta de una cosmovisión - sincretista y ecléctica respecto de diversas tradiciones culturales y autores - de toda la realidad, presentada como nueva conciencia integral ecológica y holística, que sin un cuerpo doctrinal preciso y homogéneo, encuentra en la dimensión religiosa su mayor florecimiento como expresión de una espiritualidad panenteísta, cósmica e inmanente. ${ }^{19}$

Las pretensiones de verdad absoluta de las religiones tradicionales son denegadas para constituir, en cambio, una espiritualidad tipo collage acorde con el antojo individual. Serán muchos, tantos como individuos e iguales en validez (¿o invalidez?), los caminos espirituales para el restablecimiento de la unidad de todo lo que es, esto es, para la fusión de las partes en el todo divino. ${ }^{20}$

\section{El pensamiento en descrédito: ¿una artimaña irracionalista?}

Como resultado de la amplia penetración de las diversas espiritualidades de la Nueva Era en la cultura popular contemporánea, es posible topar con su frecuente presencia en los medios masivos y digitales de comunicación. Por radio o televisión, en redes sociales y servicios de mensajería instantánea, se difunden cotidianamente mensajes breves, fragmentarios y descontextualizados que, sin mayor trasfondo, se ofrecen al arbitrio de la interpretación más acorde con el antojo del emisor y el receptor en turno. A manera de ejemplo, el siguiente texto atribuido a Krishnamurti: ${ }^{21}$ "La mente, obsesionada por el pensar, ha perdido

${ }^{19}$ Juan Carlos Gil y José Ángel Nistal, “New Age”: Una religiosidad desconcertante, 1994, Barcelona, Herder, p. 193. En este texto es posible encontrar un listado amplio de técnicas, escuelas y prácticas contemporáneas que, a consideración de los autores, presentan las características básicas y pueden ser, por tanto, consideradas propias del movimiento de la Nueva Era.

${ }^{20}$ Cfr. Jacqueline Hodder, "Spirituality and well-being: 'New Age' and 'evangelical' spiritual expressions among young people and their implications for well-being", International Journal of Children's Spirituality, vol. 14/3 (2009), pp. 197-212.

${ }^{21}$ Orador y escritor indio nacido en 1895 y muerto en 1986, asociado originalmente al movimiento teosófico. 
contacto con su incondicionada libertad original, se ha dejado limitar por el tiempo y ha reducido su espacio a la identificación. Al librarse del pensar recobra un espacio inmenso y otorga un nuevo sentido al tiempo". ${ }^{22}$ Más allá de lo problemático de la afirmación como tal, nos interesa resaltar que puede ser interpretada y, peor aún, utilizada, en su fragmentariedad y aislamiento, como una incitación a desechar de tajo y sin distinción cualquier forma de pensamiento: al librarnos del pensar nos libramos, sí, del razonamiento soberbio, obsesivo, parcial, estéril y neurótico que, por su intrínseca limitación humana, nos impide alcanzar grados más altos y profundos de conocimiento y de libertad, pero también nos libramos del pensamiento pertinente, fructífero y crítico que, en su área de competencia, produce conocimiento y orienta nuestra conducta y nuestra capacidad de elección. Al calificar al ejercicio de pensar únicamente a partir de sus limitaciones y deficiencias y promover su indiscriminado abandono, dejamos también de lado el ejercicio rico de razonar para, con sus justos límites y alcances, procesar críticamente nuestro siempre perfectible y aproximativo conocimiento de la realidad. Recalquemos: aquí no ponemos en cuestión la sabiduría ancestral de las distintas prácticas meditativas, sino la tergiversación que de ellas hacen algunas de las nuevas escuelas y métodos para rehuir al examen crítico al cual pueden y deben ser sometidos.

En los diversos movimientos de la Nueva Era es posible encontrar múltiples ejemplos de aseveraciones con una notoria connotación negativa en lo referente al ejercicio racional. No pretendo ser exhaustiva; invito al lector a cerciorarse por sí mismo y a realizar su propia recolección de ejemplos, que garantizo encontrará con facilidad. El Método Pathwork, por mencionar alguno, invita: "Suelta la actividad de la pequeña mente y da espacio para que surja un tipo diferente de conocimiento". 23

Los científicos y los artistas han compartido la experiencia de que sus logros más creativos, o sus revelaciones más profundas acerca de la naturaleza del universo, llegaron cuando por fin soltaron el duro trabajo mental

${ }^{22}$ Texto recibido a través del servicio de mensajería instantánea WhatsApp, sin mayor información referente a su fuente.

${ }^{23}$ Thesenga, op. cit., p. 359. 
y dejaron que surgiera a través de ellos alguna sabiduría o profunda visión. [...] Toda la creación es un asunto de "canalizar" la realidad interior hacia el exterior, dejando que se manifiesten la sabiduría, el amor y la belleza inherentes al universo. ${ }^{24}$

En entrevista con miembros de algunos de estos movimientos, ante nuestras preguntas sobre su origen o su fundamento, hemos recibido respuestas como la que sigue: "Piensa usted demasiado. Mientras siga atrapada en las telarañas de su mente no podrá tener acceso a la experiencia de la cual le hablamos". ¿Qué de sospechoso podría haber detrás de la aparente nobleza de buscar contribuir al bienestar humano? ¿Qué de reprochable podría haber en ello? Más que intentar dar respuesta a estas preguntas, cabe plantear otras más: ¿Es que acaso la mente es un auténtico obstáculo que debe ser eliminado o acallado para alcanzar la experiencia de la verdad, o se trata más bien en estos casos de la evasión de la crítica, del escape de los cuestionamientos por falta de argumentos sólidos? ¿Es esta especie de irracionalismo resultado de un auténtico misticismo intuicionista o se trata más bien de una artimaña para dar vuelta al examen crítico y atraer adeptos dóciles, maleables y fácilmente sugestionables?

\section{De los peligros de la suspensión de la razón}

En el viejo y siempre presente problema de la relación entre la razón y la fe, es posible encontrar diversos planteamientos según los cuales la racionalidad constituye un obstáculo insalvable para el descubrimiento experiencial de lo sagrado en la realidad humana. Ya, por ejemplo, en Kierkegaard, protestante, considerado padre del existencialismo, se encuentra la necesidad de suspender la razón para saltar, mortalmente y sin red, al territorio de la fe, el terreno de la excepción por excelencia, de la ausencia de normas y generalidades y de la paradoja absoluta. Nada aporta la racionalidad, desde esta perspectiva, a lo referido directamente a la divinidad o, en términos más amplios, a lo sagrado, que cae fuera

${ }^{24}$ Ibid., pp. 368 y 369 . 
del ámbito de la argumentación y del conocimiento empírico o especulativo, es decir, de lo cognoscible comunicable. Sobre Abraham, el heterónimo kierkegaardiano Johannes de Silentio afirma: “Abandonó una cosa, su razón terrestre, y tomó otra, la fe; si no, pensando en lo absurdo de su viaje no habría partido". ${ }^{25}$

La excepcionalidad del caballero de la fe kierkegaardiano va impregnada de un carácter trágico, esto es, el individuo es interpelado, incluso en contra de su voluntad, en el encuentro con el Absoluto y, en medio de un profundo terror existencial, como fin exclusivo en sí mismo, es llamado a trascender la esfera racional y segura de la ética de la cual es observante fiel. ${ }^{26}$ En el caso de las espiritualidades posmodernas de la Nueva Era, por el contrario, pareciera existir una búsqueda y promoción activa de la excepción; no, desde luego, de una excepción radicalmente exigente como la asumida por Abraham, prototipo y padre de la fe según Kierkegaard, sino una más emparentada con la excentricidad cómoda y llamativa, el pensamiento mágico y la ruptura del orden lógico.

Sin pretender dar aquí una respuesta al problema de la posibilidad del conocimiento de lo divino, consideramos que algunas formas de las nuevas espiritualidades confunden en su irracionalismo dos niveles radicalmente distintos: en primer lugar, el de lo propiamente sagrado en la experiencia religiosa o espiritual y, en segundo, el relativo a las condiciones históricas, los fundamentos doctrinales y las implicaciones epistémicas, éticas, sociales, políticas y económicas de cada movimiento, escuela o iglesia en su carácter institucional. Concedemos como posible, entonces, alegar en el primero de los niveles la necesaria suspensión de la racionalidad para trascender las limitaciones humanas y hacer posible el encuentro experiencial con lo divino, pero en ningún caso reconocemos justificación alguna que sea válida para negar el lugar del pensamiento discursivo en el mencionado segundo nivel, a no ser

${ }^{25}$ Søren Kierkegaard, Temor y temblor, 2003, Buenos Aires, Losada, trad. de Jaime Grinberg, p. 21.

${ }^{26}$ Cfr. Johannes Thumfart, "Schmitt como lector de Kierkegaard: El individuo y el Estado ante la excepción”, en Catalina Dobre, et al. (comps.), El individuo frente a sí mismo: El pensamiento de Søren Kierkegaard, 2014, México, Rosa Ma. Porrúa, pp. 327-329, 334 y 335. 
que sea por pura arbitrariedad, ocultamiento y evasión tramposa de la crítica. Cualquier institución, si es seria, habrá de poder ofrecerse al escrutinio con transparencia, libertad y confianza.

Ayn Rand plasma, en El manantial, las peligrosas consecuencias de suspender inadecuadamente el ejercicio de la razón y la indudable conveniencia de dicha suspensión para los perversos intereses de quienes pretenden hacerse del poder en cualquiera de sus formas. En palabras del cínico personaje Ellsworth Toohey, leemos:

Los hombres tienen un arma de defensa: la razón. Córteles ese soporte con cuidado. Pero no niegue francamente. No niegue nada francamente; si no, le descubrirán el juego. No diga que la razón es mala, aunque algunos hayan ido tan lejos con sorprendente éxito. Diga solo que la razón es limitada. Que hay algo por encima de ella. ¿Qué? Tampoco tiene que ser demasiado claro: "Instinto", "Sentimiento", "Revelación", "Intuición”, "Dialéctica materialista". Si llega a un punto crucial y alguien le dice que su doctrina carece de sentido, tiene que estar preparado para contestar. Dígale que hay algo por encima de los sentidos. De ahí que no debe tratar de pensar, sino de "sentir". Él debe “creer". Suspenda la razón y juegue a su manera. La cosa marcha de cualquier manera que usted lo desee y cuando lo necesite. Ya lo ha conseguido. ¿Puede gobernar a un hombre de pensamiento? No queremos a ningún hombre de pensamiento. ${ }^{27}$

En sociedades en las cuales, a pesar de los avances científicos y tecnológicos incorporados a la vida y a los bienes y servicios cotidianos, predominan el analfabetismo científico y la ausencia de pensamiento crítico, charlatanes y mercaderes encuentran suelo fértil para la construcción de negocios deshonestos impunemente rentables. Con pobres barnices seudocientíficos basta para convencer a un público hambriento de soluciones y certezas de las bondades de productos milagro, liberaciones espirituales en diez pasos y recetas fáciles y sencillas para alcanzar la felicidad. Múltiples y variopintos gurús ofertan sus promesas a un mercado irracional y emocionalmente desorientado y compiten por sus almas — y por sus bolsillos — con sabidurías de marca registrada.

\footnotetext{
${ }^{27}$ Ayn Rand, El manantial, 1959, México, Continental, trad. de Luis de Paola, p. 480.
} 
Carl Sagan, el célebre astrónomo que dedicó buena parte de sus esfuerzos a la divulgación de la ciencia y al desmantelamiento de falsedades y engaños presentes en los medios de comunicación, la publicidad y el mercado, sostenía: "La seudociencia es más fácil de inventar que la ciencia, porque hay una mayor disposición a evitar confrontaciones perturbadoras con la realidad que no permiten controlar el resultado de la comparación". ${ }^{28}$ En su misma formulación, los postulados seudocientíficos se blindan inmunes a la comprobación y a la refutación y recurren, para atrapar a su público, al atractivo señuelo de lo extraordinario y lo maravilloso y, "como la divisa intelectual ha sido tan devaluada, como la credulidad — antigua y de la Nueva Era - es tan agresiva, como raramente se practica el pensamiento escéptico, no hay ninguna parodia demasiado inverosímil". ${ }^{29}$

Reconocer los límites del pensamiento y la existencia de otras formas de conocimiento a partir de la intuición, la emocionalidad o la experiencia, no tiene por qué significar la invalidación de la eficacia ni lo imprescindible de aquel en el área de su competencia, y mucho menos su abandono y olvido. Pareciera que lo que la Nueva Era satisface, obedece en realidad al hambre de prodigios y experiencias extraordinarias de una sociedad cómoda, vaciada e inmediatista, que se regodea más en el espectáculo que en la vivencia profunda, silenciosa, sutil y trabajada de la espiritualidad íntima.

\section{La terrible responsabilidad y el invaluable privilegio de pensar por uno mismo}

No cabe duda de que el ejercicio de la crítica puede ser una tarea ardua y solitaria. El escepticismo puede, por momentos, convertirse en una pesada carga cuando el anhelo de encontrar respuestas inamovibles y

${ }^{28}$ Carl Sagan, El mundo y sus demonios: La ciencia como una luz en la oscuridad, 2000, Barcelona, Planeta, trad. de Dolors Udina, p. 31.

${ }^{29} \mathrm{Ibid}$., p. 262. Para profundizar en la problemática, se sugiere revisar el documental $\mathrm{An}$ honest liar (2014), de Justin Weinstein y Tyler Measom, en el que se expone un caso mencionado por el propio Sagan en la obra citada y se muestra el anhelo del gran público de creer en caminos y soluciones fáciles para sus problemas existenciales, con la consiguiente posibilidad que ello abre a los charlatanes para fabricar engaños escandalosamente lucrativos. 
un sólido sentido de pertenencia envuelve al individuo en la incertidumbre y la desesperación.

La rigurosidad y la criticidad propias de la argumentación filosófica y del método científico los hace no perder nunca de vista sus alcances y sus límites, y mantener fuera de sí las pretensiones dogmáticas del conocimiento absoluto, seguro y acabado — estas últimas presentes, velada y paradójicamente, en las teorías vagas, imprecisas y superficiales de la Nueva Era- La criticidad está lejos de significar cerrazón. Sobre la actitud científica, Sagan afirma: "[la ciencia] insta a un delicado equilibrio entre una apertura sin barreras a las nuevas ideas, por muy heréticas que sean, y el escrutinio escéptico más riguroso". ${ }^{30}$

Sin dejar de conceder que la fe posee su propio ámbito, radicalmente inalcanzable y en sí mismo inaprensible para las capacidades cognitivas humanas, los movimientos espirituales y religiosos ocupan asimismo, en su carácter histórico, un lugar terrenal netamente humano cuyas implicaciones éticas, sociales, políticas y económicas son, por tanto, plenamente susceptibles de ser sometidas a un examen crítico, empírico y racional, que valore su integridad y solidez en cada una de dichas esferas, sintomáticas de su seriedad y autenticidad. En todo caso, de lo que aquí se trata es de decidir críticamente, hasta donde ello sea posible, el salto de la fe, aun a partir del reconocimiento de la radicalidad de su riesgo. El examen atento de los diversos y múltiples movimientos y métodos que se nos ofrecen como alternativa de vida espiritual en lo relativo a su contexto histórico, ideológico y sociocultural, a su contenido teórico y su praxis, así como a sus derivaciones personales en lo psicológico, lo moral, lo social e, incluso, lo financiero, deberá evitarnos o, al menos, reducir el peligro de dar un salto suicida, cual víctimas crédulas de falsos profetas. Si queremos saltar, si hemos de saltar, se trata, en último término, de elegir consciente, comprometida y responsablemente dónde hacerlo.

${ }^{30}$ Ibid., p. 46. 
CITAM Derechos Reservados.

La reproducción total o parcial de este artículo se podrá hacer si el ITAM otorga la autorización previamente por escrito. 


\title{
LAS RELACIONES
}

DEL CRISTIANISMO

Y EL GOBIERNO

IMPERIAL ROMANO

EN LOS TIEMPOS DE

AGUSTÍN DE HIPONA

Roberto Jaramillo Escutia*

RESUMEN: En este artículo se pretende clarificar el desarrollo de las relaciones entre el Imperio romano y la Iglesia católica durante la vida de san Agustín (354-430). Se pone especial énfasis en las motivaciones político-religiosas de los emperadores romanos de esa época, así como en el aspecto político-social de algunas controversias doctrinales en el seno del cristianismo (herejías).

\author{
yod \\ THE RELATIONSHIP BETWEEN CHRISTIANITY \\ AND THE GOVERNMENT OF THE ROMAN EMPIRE DURING \\ THE YEARS OF AUGUSTINE OF HIPPO
}

ABSTRACT: In this article, we will attempt to shed light on the relationship between the Roman Empire and the Catholic Church during Saint Augustine's life (354-430). We will focus on the politico-religious motivations of the Roman emperors during this period as well as the socio-political aspects of various doctrinal controversies in Christianity (heresy).

PALABRAS CLAVE: emperadores romanos, relaciones Iglesia-Estado, cesaropapismo.

KEY WORDS: Roman emperors, Church-State relationship, Caesaropapism.

RECEPCIÓN: 7 de noviembre de 2016.

APROBACIÓN: 14 de febrero de 2017.

*Universidad Pontificia de México. 
CITAM Derechos Reservados.

La reproducción total o parcial de este artículo se podrá hacer si el ITAM otorga la autorización previamente por escrito. 


\title{
LAS RELACIONES \\ DEL CRISTIANISMO \\ Y EL GOBIERNO \\ IMPERIAL ROMANO \\ EN LOS TIEMPOS DE \\ AGUSTÍN DE HIPONA
}

\begin{abstract}
Agustín de Hipona vivió del 13 de noviembre de 354 al 28 de agosto de 430 . Recientemente, hace menos de diez años, su persona fue escogida para proponer cinematográficamente la debacle del Imperio romano de Occidente, y me parece que también es un ejemplar único para iluminar esas relaciones iniciales, que todavía en su tiempo no podemos llamar Iglesia-Estado, pues no se puede hablar de un ente denominado Iglesia cristiana como de algo homogéneo, que actuara al compás de unos mismos acuerdos, o algo por el estilo.
\end{abstract}

\section{Antecedentes}

Para situarnos convenientemente en esas relaciones del Estado imperial romano y el cristianismo, antes del nacimiento de este, debemos tener claro que en las instituciones imperiales nada podía ser concebido fuera del Estado y menos en su contra. La religión grecolatina era una función del Estado; por lo mismo, se trataba de una simbiosis perfecta, en la que la autoridad civil fungía a la vez como sacerdote del culto tradicional. En consecuencia, era impensable que pudiera surgir un problema de libertad religiosa. Como la religión era considerada una institución pública, perteneciente al patrimonio político de la comu- 
nidad, no del individuo, ningún ciudadano habría podido adoptar su propia religión, en contraste con la de la respublica; luego, no debía existir diferencia alguna entre el ciudadano y el fiel participante del rito dedicado a los númenes (es más, para ser ciudadano se debía venerar a la misma divinidad).

Por otra parte, conforme se fueron uniendo al Imperio diferentes pueblos, con distintas divinidades nacionales, estas fueron consideradas óptimas para esos pueblos, y los romanos no dudaron en acogerlas erigiéndoles su respectivo templo en la capital, el Pantheon. No estaban muy seguros de venerar a todos los númenes del universo, pero tampoco podían prohibir divinidades particulares, para no ofenderlos ni crear conflictos que podrían ser muy perjudiciales para la paz del Imperio. Por esto, como factor de unidad religiosa y símbolo de unión con la nueva entidad política, se sobrepuso el culto imperial, como signo de fidelidad, y así se respetaban plenamente los principios religiosos de los pueblos. En cambio, los cristianos no podían invocar ninguna benevolencia, pues su divinidad no era la de un pueblo y además era exclusivista, al grado de no compartir con otras divinidades ningún signo de culto exterior.

En este contexto, las órdenes imperiales exigían a los ciudadanos cumplir con determinados ritos a los dioses, que los cristianos no acataban, por lo cual llegaban a ser ajusticiados. Las órdenes no tenían la intención de prohibir esa religión ni de perseguirlos sádicamente, sino que les pedían que manifestaran con los signos debidos, esos sí ritos culturales, su fidelidad como ciudadanos al Imperio. Es decir, no había separación entre lo civil y lo religioso, sino que más bien se provocaba una confusión; lo civil se manifestaba con signos religiosos, y estos convertían al participante en ciudadano, cives. Así, podemos afirmar que cuando se concedió licitud al cristianismo, se inició una incipiente división entre lo civil y lo religioso, que como vamos a ver duró poco tiempo.

El cristianismo pasó de ser una religión ilícita a convertirse en la religión preferida del emperador Constantino. Este paso tan radical era impensable, pues cuando más se aspiraba a un modus vivendi, una simple tolerancia; tanto, que este giro radical provocó muchas veces, en ambas partes, que no se pudiera establecer un punto justo de equilibrio. Más, 
si tenemos en cuenta que se calcula que a comienzos del siglo IV solo una décima parte de los habitantes del Imperio eran cristianos.

Se había llegado a esta situación por obra de dos documentos: el Edicto de Sárdica y el Acuerdo de Milán; pero tuvo mayor importancia la actitud benevolente de Constantino, aunque no se haya bautizado hasta encontrarse en el lecho de muerte. El Edicto de Sárdica, dado por el emperador Galerio el 30 de abril de 311, reconoció al cristianismo como religión lícita, pero no le devolvió los bienes que los edictos de Diocleciano le habían confiscado. Este documento es importante para nuestro tema, pues afirma que la finalidad de las persecuciones es conducir a los cristianos a las leyes y costumbres de sus antepasados y a lo que llama publicam disciplinam romanorum, es decir, a que se comporten como ciudadanos. Esta licitud del cristianismo inició cierta separación entre el gobierno imperial y una religión que no era la oficial ni la de algún pueblo incorporado al imperio.

El Acuerdo de Milán se atribuye normalmente a Constantino, pero hay que aclarar el hecho histórico: no es edicto, ni lo dictó Constantino ni se promulgó en Milán; se trata de un rescripto enviado por el emperador Licinio al gobernador de Bitinia, tras haber quedado como único gobernante de Oriente, el 13 de junio de 313. Ciertamente, se trata de un documento pactado en Milán entre Constantino y Licinio, cuando este último iba a contraer nupcias con la hermana del primero, Constancia. En él se proclama el principio de libertad religiosa, con referencia especial a los cristianos, y se les restituyen los lugares de culto y los bienes inmuebles confiscados durante la persecución.

\section{La época constantiniana (312-337)}

Como se indicó, lo más importante para el desarrollo del cristianismo fue la actitud imperial. Su acercamiento a esta religión se inició en los días previos a la batalla de Puente Milvio, el 30 de abril de 312, en la que Constantino derrotó a Majencio y conquistó Roma, y atribuyó la victoria al dios de los cristianos. Fue una adhesión al cristianismo imperfecta y por motivos no del todo sublimes, sino más bien mágicos, pero sinceros. 
Constantino llevó adelante una nueva política filocristiana, así que se puede hablar de época constantiniana, aunque su bautismo haya ocurrido el 22 de mayo de 337, día de su fallecimiento.

Único emperador desde el 324, en el régimen de Constantino se puede valorar con bastante claridad, por una parte, su actitud hacia la religión oficial, con la que no rompió totalmente, pues conservó el título de Pontifex Maximus, pero tomó algunas medidas que limitaron su influencia; por ejemplo, despojó a los templos de sus riquezas. En cambio, al cristianismo lo colmó de favores: concedió a los obispos jurisdicción en causas civiles, estableció como día de reposo semanal el dies solis, para facilitar a los cristianos su participación en el culto (3 de julio de 321); mandó construir basílicas con gran munificencia: San Pedro, San Paulo y San Lorenzo en Roma, Santo Sepulcro en Jerusalén, la de Belén, la Aurea de Antioquía, etc. Además, comenzó la injerencia del gobierno estatal en los asuntos internos de la Iglesia, lo que se puede comprender, porque muchas veces Constantino intervino tras haber sido interpelado por los obispos, sobre todo los cortesanos. Razonaba, quizás, que si solicitaban su juicio no solo era lícito, sino obligatorio tomar una decisión en consecuencia. De hecho — según Eusebio de Cesarea-, se consideraba episkopos ton ektós, obispo para quienes estaban fuera del cristianismo, aunque como esta frase la pronunció en la inauguración del Concilio de Nicea, más coherente sería una interpretación que lo colocara como supremo moderador de tal asamblea.

Hasta aquí hemos tocado los antecedentes civiles; ahora entramos en los eclesiásticos. El problema más arduo fue el arrianismo, y en las controversias que suscitó Constantino tomó las primeras decisiones gubernamentales en el campo religioso. Según Arrio, Dios no siempre había sido Padre, pues el Verbo fue creado de la nada, pero no desde un principio, por lo que el Hijo era una criatura, no era igual al Padre en cuanto a la substancia y fue hecho solo para que por su medio Dios nos creara; de lo contrario, no hubiera existido jamás. Esta doctrina fue condenada en Alejandría en 321. Arrio se refugió en Cesarea de Palestina, donde con el apoyo del obispo Eusebio, padre de la historia eclesiástica, difundió por todo el Oriente su doctrina. 
El emperador Constantino, viendo que peligraba la paz religiosa, envió a Alejandría a su consejero eclesiástico, el obispo de Córdoba Osio, quien no logró la paz pero se dio cuenta de la importancia del asunto, por lo que recomendó la celebración de un concilio. Constantino aceptó, y así se verificó el primer concilio ecuménico, el Concilio de Nicea, inaugurado por el propio emperador el 20 de mayo de 325. Ahí se afirmó, en contra de Arrio, la consustancialidad del Padre con el Hijo, usando por primera vez un término no bíblico, Homoousios to Patri, susceptible de interpretación errónea y que por ello topó con grandes dificultades para su aceptación.

Como Constantino había decidido que quienes no firmaran las actas conciliares serían exiliados, y efectivamente lo cumplió, incluso con quienes más tarde se arrepintieron, los partidarios de Arrio optaron por no atacar el concilio, sino a los defensores de Nicea, y así la controversia se eternizó, ya que en Oriente se sentían más convencidos de la doctrina de Arrio.

En cuanto al cisma africano, el donatismo, que de ser un movimiento estrictamente religioso se transformó en uno político y social, había surgido con el primer decreto de persecución de Diocleciano, que ordenaba consignar los libros sagrados para quemarlos. Muchos obedecieron el edicto. Aquí debo subrayar que en el cristianismo nunca se han considerado sagrados los libros, pero entonces pareció una especie de traición, y para tapar esa falla, se acuñó una doctrina según la cual solo son miembros de la Iglesia los santos, por lo que la santidad de la Iglesia depende de la santidad de sus miembros y la validez de los sacramentos depende de la santidad o dignidad del ministro. Ya en tiempos de paz, se produjo una duplicidad de obispos en Cartago. Se adujo que uno de los obispos que consagraron a Ceciliano había consignado libros y, por lo tanto, era inválida su consagración. El nombre proviene de Donato, apodado el Grande, que desde 313 dirigió a los cismáticos.

Los del bando de Ceciliano acudieron a Constantino solicitando un juicio imparcial de los obispos de la Galia, que no habían sufrido la persecución. No acataron la primera evaluación dada en un sínodo romano, apelaron nuevamente $y$, antes de darles otra oportunidad, Constantino mandó hacer una investigación judicial basada en las actas de consig- 
nación, que resultó negativa para el acusado. Se reunió una nueva asamblea en Arlés en agosto de 314, en la que de nueva cuenta resultaron condenados los donatistas, que ya estaban rebautizando a sus fieles.

Dado que Constantino le daba gran importancia al orden público, tuvo una actuación vacilante. No aplicó la decisión de Arlés, sino que envió dos comisarios a África para que emprendieran una nueva investigación en el verano de 316 . Los comisarios confirmaron que Ceciliano era el obispo legítimo. Los cismáticos se entregaron a actos de violencia, lo que obligó a Constantino a publicar una ley el 10 de noviembre de 316, por la que debía restablecerse por la fuerza la unidad religiosa en África. La ley fue aplicada con rigor por la tropa, y hubo muertos y heridos, con lo que los cismáticos tuvieron a sus propios mártires, signo de veracidad para su iglesia.

Esto es importante, porque a partir de entonces se formó un grupo religioso particular que cuidaba del culto martirial, los circumceliones, fanáticos que se convirtieron en terroristas muy temidos, pues la muerte no les importaba, sino que la aceptaban como martirio. En este primer periodo de proscripción, el donatismo se convirtió en un movimiento complejo, que aprovechó el descontento de las clases desheredadas africanas para transformarse en una opción política contra el Estado, de modo que proclamó, por primera vez, la separación entre el cristianismo y el gobierno imperial. Cuando Constantino se preparaba para atacar a Licinio, aceptó el 5 de mayo de 321 una solicitud de tolerancia para los donatistas. En adelante, el emperador mostró una actitud benévola, con lo que el movimiento se difundió extraordinariamente.

\section{Los hijos de Constantino (337-361)}

Constantino, al crear una dinastía absoluta, parece que pensó en el mayor de sus hijos con Fausta, Constantino II, como sucesor, aunque otros suponen que proyectó un colegio de augustos jerarquizado, una tetrarquía familiar. Como no dejó nada establecido, sus hijos hicieron una masacre de todos los miembros varones de la familia, de la que únicamente se salvaron, por su corta edad, su sobrino Galo y su hermano 
Juliano. A partir de ese momento, el poder quedó dividido en dos. De un lado, la mentalidad imperial en Oriente y del otro en Occidente, incluso cuando se trate de la misma persona.

E1 9 de septiembre de 337, sus hijos sobrevivientes fueron declarados augustos por el Senado y se dividieron el Imperio, dejando con la peor parte al supuesto heredero, Constantino II, pero como el menor, Constante, sospechó que su hermano quería quitarle su territorio, se alió con Constancio II, y lo liquidaron en 340. Constante se quedó con el Imperio de Occidente hasta su muerte, asesinado, diez años después, el 18 de enero de 350. Constancio II fue el señor de Oriente y único emperador desde 351, cuando venció al asesino de su hermano, Magnesio, en Mursa.

Durante el gobierno de estos hermanos se dieron varios decretos de prohibición del culto grecolatino y cerraron templos, lo que se debió atemperar, pues las festividades de los númenes eran el origen de los juegos de los pueblos, y no era aconsejable la terminante desaparición de los lugares de culto. Estas medidas provocaron la destrucción de joyas del arte universal.

En cuanto al donatismo se refiere, con Constante como único emperador de Occidente hubo un nuevo intento de unidad, por medio del diálogo con los cismáticos, y se ofrecieron dones a las comunidades, lo que enojó tremendamente a Donato. Ante las protestas de Donato, Constante renovó el edicto de unión de su padre del 15 de agosto de 347, disolvió las comunidades cismáticas y exilió a quienes se opusieron, entre ellos el propio Donato. Otra vez hubo violencia y mártires donatistas, y esta situación se extendió hasta el ascenso de Juliano al trono.

Tornemos al arrianismo, que con los hijos de Constantino alcanzó su apogeo, precisamente con el apoyo imperial. La razón parece estar en que tratándose de un problema oriental, fue en esa región donde la decisión de Nicea tuvo más detractores, y por lo tanto, a los emperadores que gobernaron esa parte del imperio les parecía que para lograr una paz religiosa, tendrían que apoyar al bando contrario. Así, por un lado, Constante se preocupó por restablecer el diálogo entre las iglesias de Occidente y Oriente, hasta lograr que se condenara el arrianismo puro 
y se moderara la actitud de su hermano Constancio II, pero una vez que este quedó como único gobernante, influido por los más radicales apoyó firmemente a la facción antinicena y trató de expandir un semiarrianismo por todo el imperio. Tan fuertes se sintieron los antinicenos por el apoyo imperial, que se dividieron en sectas enfrentadas por un antagonismo feroz. Se exiliaron unos a otros y causaron una verdadera confusión episcopal, por existir muchos obispos sin sede.

Constancio II, una vez que se desembarazó del usurpador Magnesio, comenzó a extender su plan en Occidente, y para atemorizar a los obispos, cuando estos se negaban a cumplir sus mandatos, pronunció frases como esta: Et quod ego volo, id pro canone habeatur, y lo que yo quiero se tenga por mandato. Ya desde el mismo Concilio de Milán de 355, donde pronunció tales palabras, los mismos obispos le respondieron que no tratándose de asuntos temporales, sino religiosos, no podía juzgar su conveniencia, aunque después los convenció uno tras otro. Quien resistió siempre fue el casi centenario consejero religioso de su padre, Osio de Córdoba, que respondió duramente a una carta personal de Constancio II, diciéndole que no le era lícito ni tenía poder para ejercer funciones de sacerdote, así como los obispos no mandaban en las cosas terrenas. Constancio II, no obstante la edad de Osio, lo exilió.

En buena medida, se debe achacar esta actitud a los obispos palaciegos que se valían del poder de Constancio II y lo adulaban llamándolo episcopus episcoporum, "obispo de los obispos". Con este mutuo apoyo el emperador legisló en cuestiones dogmáticas y se erigió en el primer cesaropapista por sistema. Quería restituir la paz y la unidad religiosa, pero él era el primer impedimento, pues con su injerencia provocó grandes desórdenes. Constancio II enfermó gravemente de improviso y falleció el 6 de noviembre de 361, bautizado, como su padre, en el lecho de muerte. Siete años antes había nacido Agustín en Tagaste de Numidia.

\section{Juliano el Apóstata (361-363)}

Asumió el gobierno del Imperio Juliano, sobrino de Constancio II, que en ese momento se encontraba en marcha hacia Constantinopla para atacar a su tío. Constancio II le había encomendado el gobierno de las 
Galias, pero a finales de 359, le solicitó algunas legiones para la guerra contra los Persas. Las tropas se amotinaron y proclamaron Augusto a Juliano. Como Constancio II no lo aceptó, bajaba en son de guerra cuando en Naissus se sometió en febrero de 361 al taurobolio, abrazó como dios personal al sol y ofreció sacrificios a los dioses. Juliano llegó a Constantinopla el 11 de diciembre, le organizó a su tío unos solemnes funerales y decretó su apoteosis, aunque lo sepultó en la Basílica de los Santos Apóstoles. Su reinado fue corto, pues murió el 26 de junio de 363, y aunque aparentemente se dedicó a preparar la lucha contra los persas, se dio tiempo para muchas cosas más.

Juliano fue un hombre de grandes cualidades. Pagano convencido, místico, dedicó su gobierno a la obra para la cual pensaba los dioses lo habían elegido, es decir, a restaurar su culto. Ingenuamente, como iluminado, creyó que podría transmitir su íntima espiritualidad, por la cual daba más importancia a los principios de la caridad, al perfeccionamiento ascético y a una teología espiritual, que a la consecución de bienes y cargos materiales. Sumamente religioso, estimaba más el título de Pontifex Maximus que el de Augustus, por lo que de inmediato hizo construir en Constantinopla un gran templo a Mitra. Se trataba de una vuelta a la amalgamación del poder político con la religión.

Antes de terminar 361 ya había promulgado varios edictos para restaurar el culto a los dioses, reabrir sus templos, restituirles todos sus objetos, incluidos mármoles o columnas empleados en otros edificios (debían restaurarlos o reedificarlos quienes los habían destruido). Pretendió una renovación del helenismo, como él lo llamaba, inspirándose en el cristianismo: a) Organizó la jerarquía: En el vértice él, Pontifex Maximus, en cada provincia un pontífice, en cada ciudad un archisacerdote, todos nombrados por él, que cuidaría llevaran una vida ejemplar. b) Culto: descendía a los mínimos detalles, himnos, cantos, música. Quería una especie de homilía en la que se explicaran los dogmas helénicos. c) Se propuso imitar la caridad de los cristianos, pues mientras que ningún judio pide limosna, mientras los impíos galileos nutren a sus pobres, es una vergüenza que los nuestros estén desprovistos de toda ayuda de nuestra parte. Como se puede apreciar, en esta renovación lo único antiguo es el culto a los dioses, el resto son cosas nuevas. 
Por otra parte, desde sus primeros edictos concedió la tolerancia religiosa para todos los cultos y todas las tendencias, aun para los galileos. Llamó del exilio a todos los obispos desterrados y devolvió la vida a la iglesia donatista en África, con la intención de fomentar las divisiones internas entre los cristianos. Además, revocó los privilegios otorgados a los cristianos por Constantino y combatió el culto martirial poniéndolo en ridículo.

Pero su plan era más ambicioso. El 17 de junio de 362 promulgó su ley escolástica, la más pérfida de todas por su aparente inocuidad. Según la ley, era necesario que los maestros estuvieran de acuerdo con las ideas de los autores que utilizaban; para ello, otorgaba al Senado el derecho de elegir a los maestros, considerando sobre todo su moralidad, la cual se entendía como la coherencia del maestro, pues pensar de un modo y enseñar de otro denotaba falta de sinceridad y honestidad y era un verdadero engaño a los alumnos. La idea era reorientar a las nuevas generaciones hacia el culto a los dioses, excluyendo de la enseñanza a los maestros cristianos y considerando las escuelas como seminarios del paganismo. Se trataba también de cerrar el camino al cursus honorum, la administración estatal, a los jóvenes cristianos que se negaran a ser instruidos por maestros paganos, ya que los maestros cristianos todavía enseñaban con los textos de los clásicos.

Todas estas medidas se basaban en la íntima convicción de Juliano de que el cristianismo había echado a perder la gran civilización helénica, como trata de probar en su obra Contra galileos, que no sobrevivió a la hoguera y de la cual solo se conservan fragmentos trasmitidos por la refutación de Cirilo de Alejandría. Para Juliano, el cristianismo, o la conjuración de los galileos, era un conjunto de fábulas y de irracionalidades inventadas por malvados, y una enfermedad de la inteligencia, derivada de la falta de cultura. Como buen conocedor del dogma cristiano, comenzó su demolición desde el Antiguo Testamento. Puso de relieve las cuestiones ilógicas, como la soberbia judía de considerarse el único pueblo elegido por Dios, cuando hubo otras civilizaciones muy superiores. Negó la divinidad de Cristo, porque los evangelistas le aplicaron arbitrariamente los textos del Antiguo Testamento; en consecuencia, 
negó también la resurrección. Odiaba especialmente a San Pablo, por ser el responsable de la conversión de los griegos, que él consideraba una forma de corrupción, y poco menos a San Juan, por haber sido el causante de proclamar la divinidad de Cristo. Se burlaba especialmente de los monjes, incitados por los demonios a odiar y apartarse del género humano, pues el hombre es un animal social. En pocas palabras, la doctrina de Cristo no era útil a la humanidad.

Muchos cristianos que se habían convertido por conveniencia, regresaron al politeísmo; sin embargo, este hiato en la cristianización del imperio más bien ayudó al cristianismo, pues cuando los obispos analizaron lo que podía ocurrir, se unieron frente al peligro y comenzaron a restablecer la unidad amenazada por el arrianismo.

Con la muerte de Juliano se extinguió la línea masculina de la familia constantiniana. Juliano no quiso designar un sucesor, con lo que pasó nuevamente la elección al ejército, que en el mismo campo de batalla aclamó a Joviniano, pero este falleció pronto, el 17 de febrero de 364.

\section{Los valentinianos y Teodosio (364-395)}

Nuevamente la tropa entregó el trono a Valentiniano I, quien asoció a su hermano Valente como segundo Augusto. Valentiniano gobernó la parte occidental y Valente la oriental. Ellos fueron los que dividieron al Imperio, funcionarios, ejército, economía, agricultura, todo. Cada Augusto se vio limitado por sus medios y trazó sus propios objetivos, encerrado en su territorio y prisionero de su egoísmo, que creció con los problemas.

En Occidente, Valentiniano I, aunque profesaba el nicenismo, en las cuestiones religiosas actuaba siguiendo el principio de neutralidad, al grado de que no le gustaba escuchar que alguien fuera cristiano por ser la religión del emperador. Así, no solo por motivos políticos, sino también porque pensaba que como laico no debía inmiscuirse en cuestiones de fe, incluso fue objeto de quejas de obispos que querían que tuviera mayor injerencia. Falleció en 375. Valente, en cambio, como en Oriente el nicenismo no era la corriente central, persiguió a sus fieles, así como también a seguidores de las corrientes menos extremistas del 
arrianismo, y los trató con métodos bárbaros. Desterró y hasta ejecutó a quienes se negaban a apoyarlo en su pretensión de unificar su Imperio bajo la corriente más radical, el omeísmo. Falleció el 9 de agosto de 378 .

La disolución del arrianismo comenzó en Occidente, con el Sínodo de París de 361, cuando las tropas de Juliano avanzaban sobre Constantinopla. También se aprovechó la libertad concedida por Constantino. Incluso el símbolo del nicenismo, Atanasio, celebró su sínodo en Alejandría. En Occidente, le imprimió mayor celeridad la elección como obispo de Milán del consularis Ambrosio, entonces catecúmeno y que se había presentado con la fuerza pública para calmar los tumultos causados por la muerte del obispo arriano Ausencio. Bautizado al poco tiempo, Ambrosio fue consagrado obispo una semana después, en 374. La importancia de este hecho se cifra en que el obispo influyó grandemente en el siguiente emperador, Graciano, y con su apoyo se puso fin al arrianismo en Occidente.

El régimen de Graciano se extendió de 375 a 383, y aunque el ejército le había asociado a su hermano menor Valentiniano II, gobernó en solitario en Occidente y por un breve periodo también en Oriente, de agosto de 378 a enero de 379, cuando designó emperador a Teodosio.

82 Con Graciano, fuertemente influido por Ambrosio, se radicalizó la separación entre el poder político y el culto grecolatino, al suprimir de entre los títulos imperiales el de Pontifex Maximus. Luego, en 382, promulgó dos constituciones por las que retiró a los sacerdotes del culto oficial sus exenciones e inmunidades, suspendió todo subsidio estatal para su culto y confiscó templos y colegios sacerdotales. Graciano ordenó también remover del aula del Senado el altar de la Victoria, donde los senadores juraban, lo que tuvo un gran significado religioso y político. Con estas decisiones, prácticamente condenaba a muerte la religión grecolatina, al quitarle el sostén económico que la sustentaba y separarla del poder imperial, el cual, en cambio, acercó al cristianismo, pues poco antes, en 380, proscribió toda herejía cristiana en el imperio. Ambrosio aprovechó esta orden para limpiar de arrianos Occidente. Ambrosio fue el que prescribió la asistencia del brazo secular para ejecutar las sentencias eclesiásticas sobre los clérigos contumaces. 
Teodosio, primero como emperador de Oriente en 379, y a la muerte de Valentiniano II, en 392, de Occidente, fue el único poder hasta su muerte ocurrida el 17 de enero de 395. Teodosio optó por la unidad religiosa del imperio como política de Estado, como el mejor medio para alcanzar la unidad política. Por esto atacó no solo el culto grecolatino, sino que también persiguió a los herejes; por esta doble razón, proclamó al cristianismo niceno religión oficial del Imperio romano, con lo que dio por terminada la libertad de religión, con el Edictum de Fide Catholica, publicado en Tesalónica el 28 de febrero de 380. En el edicto se establecía que todos los habitantes del imperio debían profesar la religión enseñada por el apóstol Pedro a los romanos y que profesaban Dámaso de Roma y Pedro de Alejandría: Hic est Patris et Filii et Spiritus Sancti, unam Deitatem sub parili maiestati et sub pia Trinitate credamus, "Creamos que el Padre, el Hijo y el Espíritu Santo son un solo Dios, con igual majestad, y bajo una santa Trinidad". Con este edicto les quitó a los herejes arrianos toda opción a la existencia, aunque tuvo que reformarlo en enero de 381, por sus pactos con las tropas de los pueblos godos, que eran arrianos, para permitirles conservar sus iglesias, aunque fuera de las ciudades, donde acampaban las tropas. Además, para que esta determinación no quedara en el aire, en noviembre de 379, Teodosio invitó al obispo arriano de Constantinopla Demófilo a abrazar la fe nicena. Como este se negó, le ordenó entregar todas las basílicas, y el día 27 acompañó a Gregorio Nacianceno, que por entonces presidía a los nicenos, a la Basílica de los Santos Apóstoles, y de propia voz lo nombró obispo de la ciudad. Más tarde, el sínodo episcopal declaró canónica esta imposición. Este gesto tuvo grandes repercusiones para la cristiandad oriental, pues a partir de ese momento la corte cumplió un papel de primer orden en la designación del obispo capitalino, incluso ya en época otomana.

Para confirmar su programa religioso, Teodosio convocó un concilio en Constantinopla en mayo de 381, que con el tiempo fue reconocido como el segundo concilio ecuménico, por el contenido de su temática. Lo inauguró, pero después no intervino. Aunque se pretendía que fuera de unidad, los de tendencia arriana abandonaron la sede conciliar antes del inicio, negándose a integrarse en el nicenismo. Lo más 
importante del concilio fue su símbolo de fe, que desde entonces será el credo de todos los cristianos hasta la fecha y la causa principal de la ecumenicidad del concilio. Confirmó el símbolo niceno, completándolo en lo relativo a la consubstancialidad y divinidad del Espíritu Santo.

Teodosio ratificó todas las decisiones conciliares con un edicto del 30 de julio de 381, en el que además proscribió a los herejes, los cuales debían entregar sus iglesias; es decir, convirtió en ley del Estado los decretos del concilio. De esta manera se desvaneció el arrianismo en el Imperio romano, pero permaneció entre los germanos y regresó en el siglo siguiente. De igual forma, el Estado se ató al cristianismo.

No terminaron con esto los empeños de Teodosio. También se lanzó contra paganos y apóstatas en varias constituciones entre 381 y 383 . Después se empeñó en facilitar el restablecimiento de la paz entre los cristianos y trató de llegar a una unanimidad doctrinal. Con una serie de edictos promulgados entre el 25 de julio de 383 y el 21 de enero de 384 reconoció únicamente el nicenismo, quitó a los herejes sus lugares de culto y privó a los apóstatas de todo derecho civil y político en 391. A los que permanecieron fieles a los dioses latinos les prohibió el 25 de mayo de 385 el ejercicio de su religión, de modo que no pudieron ofrecer sacrificios ni celebrar otras ceremonias públicas, y el 24 de febrero de 391 prohibió toda ceremonia en Roma, una prohibición que se extendió luego a Egipto. No todas estas órdenes se ejecutaron, pero algún peso tuvieron.

La Iglesia cristiana se volvió dependiente del poder imperial. Lo provocaron los mismos obispos, que continuamente recurrían a la autoridad de los emperadores para hacer valer sus puntos de vista doctrinales, con lo que se sintieron árbitros de estas cuestiones eclesiásticas. Peor aún, estas decisiones adquirieron carácter civil y, por lo tanto, se borraron los límites entre lo estatal y lo religioso, y se confundió la sociedad.

De mayor interés para nosotros es que el emperador Teodosio fue el único gobernante que oficialmente debió hacer penitencia pública para ser reconciliado por el obispo Ambrosio, la noche de Navidad de 390, tras un incidente sucedido en Tesalónica, que luego se conoció como la masacre de Tesalónica. El magister militum del pretorio de 
la ciudad, el godo Buterico, mandó arrestar a un popular auriga por haber tratado de seducir a un sirviente del emperador e incluso a él mismo. El pretorio quiso aplicar una ley contra la homosexualidad promulgada por Teodosio ese mismo año. El populacho, amotinándose, exigió la liberación del auriga, a lo que se negó Buterico, que resultó muerto en el tumulto que se sucedió. Teodosio ordenó que se tomaran represalias, de las que al parecer una contraorden no alcanzó a llegar. Las tropas enardecidas de Buterico vengaron a su jefe en el circo, donde causaron un gran número de víctimas, que algunos calculan en siete mil. Por esto, Ambrosio invitó en una carta a Teodosio a hacer penitencia, lo que aceptó, dado que como afirmaba el obispo, el emperador cristiano era parte de la Iglesia y no estaba por encima de sus normas, Imperator enim intra Ecclesiam, non supra Ecclesiam est. No se trata, como algunos autores piensan, de la humillación del poder político frente al eclesiástico, sino del arrepentimiento de un cristiano tras reconocer un pecado público, que era lo único por lo que entonces se obligaba una penitencia pública. Así, en su oración fúnebre, Ambrosio alabó este gesto de arrepentimiento de su público pecado con gemidos y lágrimas, y que orando haya pedido perdón.

Terminaremos ahora con el problema africano, el cisma donatista, ya que conocemos la actitud de los distintos emperadores. Nos habíamos quedado en la proscripción del movimiento decretada por Constante. Esta situación duró hasta 362, cuando Juliano revivió el donatismo, que aunque oficialmente suprimido, persistía en la mayoría de sus seguidores, que no se manifestaban por miedo pero eran exhortados por sus obispos desde el exilio a perseverar. Mucha culpa tiene en esto la Iglesia, pues sus obispos carecieron del entusiasmo necesario para convencer, o quizás les faltó doctrina para instruir o se dejaron llevar por la fácil victoria, pensando que eso bastaba.

Cuando los obispos donatistas se dirigieron a Juliano para solicitarle el restablecimiento de su iglesia, este lo otorgó con facilidad a principios de 362 . Les concedió libertad de culto, retorno de los desterrados y restitución de todos los bienes muebles e inmuebles confiscados en 347. Como era de esperar, tal restablecimiento fue rápido, pero no pacífico. En algunos lugares los cismáticos quisieron borrar toda 
huella de la otra iglesia y destruyeron hasta sus olores: eucaristía, crisma, cálices y altares eran tirados por las calles o raspados hasta darles otra apariencia. Incluso algunos obispos encabezaron bandas violentas, aunque otros lo desaprobaron y trataron de impedir el uso de la fuerza. Los gobernadores de las provincias, interpretando la intención de Juliano, favorecían o toleraban la violencia. En 390, los donatistas llegaron al apogeo de su historia gracias a la labor de Parmeniano, sucesor de Donato en el exilio y que solo entonces pudo tomar posesión de su sede. Con celo, se dedicó a organizar su iglesia, por lo que se le considera un segundo fundador del donatismo. A su muerte, el cisma tenía casi tantos adeptos como sus rivales.

Entre 391 y 392 murieron los jefes de las dos iglesias y se cambiaron los papeles. En lugar del "bueno para nada" Genetlio, fue elegido Aurelio, un verdadero líder, que se convirtió en cabeza del cristianismo ortodoxo en África. El puesto de Parmeniano fue ocupado por un individuo conflictivo, Primiano. Además, por esas mismas fechas entró en escena Agustín, ordenado sacerdote en 391, después coadjutor de su obispo Valerio y en 395 obispo de Hippo Regius, Numidia. Fueron ellos, actuando siempre de acuerdo, los que inclinaron la balanza definitivamente para superar el cisma.

Por esos mismos años comenzó el turbio comportamiento de Gildón, jefe tribal de los cabiles en la Mauritania Cesariense, quien había llegado a ese puesto por su colaboración en la derrota de su hermano Firmo, en 372. La fidelidad de Gildón al Imperio comenzó a vacilar ante las medidas tomadas por Teodosio. Primero, le negó ayuda contra el usurpador Eugenio y después se aprovechó de la situación del Imperio a la muerte de Teodosio. Así, se rebeló en el otoño de 397 y se declaró súbdito del Imperio de Oriente. Al cabo, fue derrotado por su hermano Mascazel, adolorido porque había asesinado a su hijo. Gildón favoreció siempre a los donatistas y sus tropas tuvieron muchos miembros del cisma. De haber triunfado, otra habría sido la suerte del cristianismo en el África romana.

Ahora bien, esto sucedió porque el donatismo hacía causa común con los pobres y oprimidos, pues en las provincias donde tuvo mayor difusión sus habitantes eran agricultores: colonos o jornaleros, oprimidos 
por los patrones o por los funcionarios imperiales. La gran paradoja del África romana (considerada una tierra de promisión, el granero de Roma, de aquí que una espiga madura de trigo, signo de la fecundidad de la tierra, representaba a la diosa África) era que ayudaba a la alimentación de medio mundo, pero se alimentaba mal a sí misma, porque los recursos estaban mal distribuidos. Solo una minoría, no africana, disfrutaba la riqueza de su suelo, con el sudor de la gran masa de trabajadores nativos. Por haber sido conquistada en las guerras púnicas, era propiedad estatal por derecho, y al Estado pertenecían las ricas planicies, que habían sido repartidas entre la clase senatorial. Constantino, en su legislación para asegurar la manutención del Imperio y para evitar los continuos fraudes al fisco, había vinculado al campesino — colono, como se le llamaba - a su tierra, haciéndolo esclavo, en lo que se considera el inicio del siervo medieval. En 371, Valentiniano I ordenó: "Los colonos no tengan la libertad de abandonar los campos a los cuales los ligan su condición y su nacimiento. Si huyen y pasan a otro patrón sean reconducidos, encadenados y castigados". Aquí está la razón del problema, pues esta legislación, en lugar de robustecer la producción agrícola, fortaleció al patronato, ya que todos los que por malas cosechas no podían pagar los impuestos, los delincuentes comunes y hasta los criminales, huyeron a las fincas de los poderosos en busca de protección o más bien en busca de esfumarse, a cambio de lo cual ofrecían su trabajo y casi su libertad, pues difícilmente podían salirse de la finca sin correr el riesgo de que cualquiera los denunciara como fugitivos.

Estos asuntos de carácter socioeconómico se mezclaron con los religiosos. Por eso el donatismo alentaba cierta oposición política, incluso la rebelión, y evitaba todo trato con el Estado: Quid est imperator cum ecclesia, “Qué tiene que hacer el emperador en la iglesia?”, preguntaba Donato ante el tesón imperial por lograr la unidad.

\section{Los sucesores (395-430)}

A la muerte de Teodosio el 17 de enero de 395, lo sucedieron sus hijos, aunque conociendo su ineptitud, los había puesto bajo la tutela: a Arcadio, de Rufino en Oriente (395-408) y a Honorio, del vándalo Estilicón en 
Occidente (395-423). Teodosio no pensó dividir el imperio, como vulgarmente se piensa, sino que separó su administración como tantas veces se había hecho. Lo que ocurrió fue que por circunstancias posteriores, ya no fue posible la reunificación. Arcadio y Honorio se dejaron influir fácilmente y es larga la lista de quienes dispusieron del poder aconsejando a los soberanos. Lo mismo puede afirmarse de quienes los sucedieron: Teodosio II a Arcadio y Valentiniano III a Honorio (424-455). Se calcula que en este tiempo, principios del siglo V, los habitantes del imperio sumaban entre 40 y 50 millones, y se estima que los cristianos, dejando de lado si eran ortodoxos, bautizados o catecúmenos, eran la mitad de la población, o sea de 20 a 25 millones. Con menor número no se explicaría la medida de Teodosio al convertir el cristianismo en religión oficial del Estado.

Todos estos emperadores continuaron el repudio a la religión grecolatina. Así, Arcadio y Honorio promulgaron una constitución el 7 de agosto de 395 en la que prohibían la entrada a los templos paganos o de herejes, así como realizar sacrificios o actos de culto. Muchos lugares de culto sufrieron destrucción o graves daños, ya por parte de los funcionarios imperiales, ya por parte de los eclesiásticos, y se perdieron para siempre invaluables tesoros artísticos. Honorio se sintió obligado a dar una constitución, el 29 de enero de 399, en la que prohibió los sacrificios, pero mandó conservar los publicarum operum ornamenta, orden que repitió el 20 de agosto, para exigir la integridad de los edificios. En adelante, constituciones imperiales siguieron cerrando templos y prohibiendo sacrificios hasta mediados del siglo $\mathrm{V}$, por lo que podemos suponer que las órdenes no se ejecutaban de igual manera en todas las provincias.

Occidente sufrió una grave crisis administrativa, económica, social, militar al barbarizarse el ejército, y una demográfica por las inmigraciones de los pueblos germanos. Mientras estuvo al frente un ministro capaz, como era Estilicón, se pudo controlar la situación, pero al ser ajusticiado en 408, un gravísimo error político, comenzó a desmoronarse el Imperio. Alarico asaltó Roma el 24 de agosto de 410, lo que causó verdadero pánico en la Antigüedad, que tomó el hecho como un signo fehaciente del fin del mundo. En estas fechas Agustín escribía La ciudad 
de Dios, para refutar la tesis de los senadores romanos de que adorando el Imperio a los dioses era fuerte e invencible, pero que con el cambio de religión era presa de quien quisiera invadirlo. Efectivamente, muchos pueblos traspusieron la frontera norte del Imperio, pero no intentaban apoderarse de él ni mucho menos destruirlo, sino acogerse a las instituciones romanas. Desde tiempos de Augusto, pueblos enteros quedaron integrados al Imperio, incorporados predominantemente a las tropas, en las que algunos llegaron al mando supremo del ejército. Estas migraciones, mientras hubo un buen emperador o jefe pudieron ser controladas y aun absorbidas, pero al faltar una cabeza y ante la cantidad de pueblos que se cruzaban por hambre los límites del Imperio, se produjo una situación que terminó con la institución imperial en Occidente en 476. Se rompió un equilibrio inestable.

La parte oriental del Imperio tuvo ministros que fueron administradores capaces y manejaron mejor las invasiones de los bárbaros, ya pagando tributo para que realizaran sus fechorías en otro lado (en Occidente, con poca lealtad) ya apaciguándolos con prebendas, como por ejemplo al nombrar a Alarico, magister militum del Ilírico, con lo que lograron mantenerlo a distancia. Prueba de que no todo estaba perdido es la recopilación jurídica hecha bajo Teodosio II, el llamado Códice Teodosiano, publicado en 438, que reunió las constituciones imperiales de 312 a 437 y se convirtió en una de las bases de nuestro actual derecho.

Durante esta declinación constante del Imperio de Occidente, el emperador Honorio prestó su apoyo al cristianismo ortodoxo, en contra del donatismo, al que le aplicó las constituciones imperiales decretadas por su padre a los herejes, sin duda también con motivaciones políticas, por haber apoyado el levantamiento de Gildón, en el que fue ejecutado un obispo donatista muy amigo del derrotado.

Estas leyes solo se aplicaban esporádicamente, con las consiguientes respuestas violentas de los circumceliones contra fieles y clero de la otra iglesia. Honorio, cansado por las continuas quejas, el 5 de marzo de 405 quiso poner término a estas violencias con un nuevo Edictum de Unitate, con el que renovó los edictos dados por Constantino en 316 y por Constante en 347. Honorio equiparó a los donatistas con los herejes, 
los suprimió y ordenó la unidad so pena de graves castigos. La ley no fue aplicada de inmediato ni en todas partes. En algunos lugares desaparecieron las comunidades cismáticas, mientras que otras lograron sostenerse e incluso pasaron al ataque.

Era una época adecuada, ya que el donatismo estaba dividido, con un cisma en la sede de Cartago. Por otra parte, los cristianos sinceros del donatismo estaban cansados de tanta demagogia. Los obispos ortodoxos no perdieron el tiempo, sino que desarrollaron una vasta obra de propaganda y persuasión en una serie de concilios generales africanos anuales. Por otra parte, no se aceptaba tan fácilmente el empleo de la fuerza para apoyar la unidad, una cuestión que solo los hechos consumados después de 412 recibió cierta legitimación.

El momento culminante de este proceso de unidad fue la Conferencia de Cartago, que se había propuesto desde 401-402. Los obispos ortodoxos habían tenido la idea de celebrar una conferencia general entre los obispos de ambas iglesias, pero los donatistas la rechazaban siempre. Nuevamente, en el concilio cartaginense de 410 se repitió la propuesta y se enviaron delegados al emperador. Honorio aceptó la sugerencia y el 14 de octubre de 410 ordenó al tribuno Marcelino que se trasladara a Cartago para organizarla. Efectivamente, Marcelino preparó la conferencia en las termas Gargilianas de Cartago para el $1^{\circ} \mathrm{de}$ junio de 411. Cada iglesia debía elegir seis delegados, siete consejeros y cuatro notarios. Por la parte donatista fueron designados: Primiano, Petiliano de Constantina, la más alta personalidad del movimiento y gran orador, y Emérito de Cesarea, honesto y agradable. Los ortodoxos estuvieron representados por Aurelio, Agustín, Alipio de Tagaste y Posidio de Cálama. Asistieron 285 obispos donatistas y 286 ortodoxos. La conferencia representaba la máxima esperanza para lograr la unidad en la Iglesia africana.

La conferencia se verificó en tres sesiones, los días $1^{\circ}, 3$ y 8 de junio. Se leyeron multitud de documentos sobre el origen del cisma. En la tercera sesión, Agustín, orador de los ortodoxos, demostró que la Iglesia puede tener en su seno pecadores sin perder la santidad que le confiere el Espíritu Santo, y que la presencia de pecadores no es obstáculo para la comunión cristiana. Los donatistas no pudieron rechazar tales afirma- 
ciones, y como estas constituían el punto central del cisma, la noche del día 8 el presidente Marcelino declaró terminada la discusión con la victoria de los ortodoxos. El 26 del mismo mes se publicó un edicto por el que los donatistas debían regresar a la unidad, por ser los cismáticos, con pena de confiscación de bienes, cárcel y exilio para los desobedientes. El 30 de enero de 412 confirmó el emperador Honorio estas disposiciones y encargó su ejecución a los magistrados de las provincias y algunos funcionarios especiales.

Ahora bien, no pensemos que por arte de magia los donatistas obedecieron tranquilamente, ni siquiera en la polémica, pues por ejemplo en Agustín hay trazas de la presencia de los donatistas todavía en 420, y había grupos donatistas entre los bizantinos un siglo después. Lo más grave de esta turbación de la Iglesia africana fue que retardó o más bien impidió la cristianización de las tribus del interior del continente, así que cuando cayó el norte africano en poder del islam, en el siglo VII, se acabó la pujante Iglesia del África romana y el resto se transformó en una mina de esclavos.

Digamos ahora cuál es el pensamiento agustiniano sobre el Estado. Según Agustín, se debe obedecer a las autoridades temporales, aun si quienes ejercen el poder no son justos; por ello, reconocía la validez de cierta concordia, tranquillitas ordinis, con los Estados no cristianos, aunque no sea una verdadera paz, que es solo la celeste y eterna. Le parecía normal que la ciudad temporal aspirara a los bienes terrenos, aunque los bienes celestiales a los que aspira la ciudad celeste son mejores, porque el espíritu supera a la materia y lo eterno sobrepasa a lo que es pasajero.

Agustín distinguió los deberes de los gobernantes hacia Dios como hombres y otro tanto como reyes, es decir el aspecto privado y el público, aunque en cualquiera debían observar la justicia. Ahora bien, el emperador podía legislar en materia religiosa, pero de manera subordinada a la Iglesia.

No estaba de acuerdo Agustín con Cicerón en su definición de pueblo, porque los no cristianos no poseen la verdadera justicia, y por lo mismo no pueden formar un núcleo unido que sea fuente del derecho, 
aunque en la definición que propuso reconocía la existencia válida de los Estados no cristianos, porque aunque su justicia no sea verdadera, solo buscan los fines temporales. Un Estado sin justicia es una asociación para delinquir, por derecho, y de delincuentes, de hecho.

\section{Conclusiones}

1. La religión y el Estado al surgir el cristianismo formaban una amalgama perfecta, en la que el ciudadano, para serlo, debía venerar a los númenes estatales. No había ninguna separación entre lo religioso y lo político.

2. Al reconocer el Imperio romano al cristianismo como religión lícita, rompió con un principio sacro en su historia y aceptó del Estado una religión que no comulgaba con la estatal y que no pertenecía a ningún pueblo, sino a personas privadas.

3. Dado que el cristianismo se convirtió de improviso en la religión preferida por el emperador, siendo este Pontifex Maximus, y acudiendo a él los obispos como juez, fácilmente se convirtió en legislador de asuntos cristianos.

4. Es evidente que los emperadores cristianos cumplieron un papel de capital importancia tanto en su expansión dentro del imperio, como en la solución de los problemas teológicos o de disciplina interna que se ponían a su consideración. El apoyo estatal fue vital para solucionar dificultades en el campo teológico y también para alargar las controversias. Los emperadores convocaron todos los concilios ecuménicos de la época y sus resoluciones, mediante sendos edictos, se convirtieron en leyes para la ciudadanía.

5. Por lo anterior puede afirmarse que la libertad de religión proclamada por Constantino tuvo poca vigencia, seguramente porque el Estado imperial romano no estaba acostumbrado a dejar de ser eje de una religión que se estaba convirtiendo en predominante. Ya para fines de esta época, Teodosio II y Valentiniano III hablaban de crimen publicum de quien intentara desviar la doctrina cristiana. 
6. En síntesis, la amalgama perfecta entre religión y Estado al surgir el cristianismo, quedó en trance de volver a lo mismo, aunque no todos los líderes religiosos estaban de acuerdo en darle primacía al Estado. Poco más tarde, en Oriente, se fundió el cristianismo con el imperio y de ambos entes debía cuidar el emperador. En el código de Justiniano, al tratar los asuntos religiosos, se titula así el libro primero: De Summa Trinitate et fide catholica, ut et nemo de ea publice contendere audeat, "Sobre la Santísima Trinidad y la fe católica, para que nadie intente contender públicamente sobre ella". 
CITAM Derechos Reservados.

La reproducción total o parcial de este artículo se podrá hacer si el ITAM otorga la autorización previamente por escrito. 


\section{DIÁLOGO DE POETAS}

\section{Los transeúntes se desplazan por las} calles urbanas generalmente con un propósito práctico bien definido: ir de A a B, sin más; poco tiempo y atención dedican al gozo de desplazarse. Los poetas, en cambio, deambulan por las ciudades en la estela de Baudelaire, patrono de la flânerie, embebiéndose de lo que los rodea: calles, plazas, comercios, vehículos, iconos sacros y profanos, multitudes, pregones, melodías. En su callejear hospitalario, el poeta, permeable a múltiples estímulos, se deja traspasar por ellos y se llena de vivencias híbridas que se traducen, más tarde, en los versos, en sinestesias: visiones sonoras, olores luminosos y sonidos palpables; juntos, configuran la atmósfera de la metrópoli. Ofrecemos aquí el fruto de la fascinación de un poeta español por la Ciudad de México: un recorrido sensorial intenso, vertiginoso y empático por la urbe que muchos aún llamamos "el DF".

Javier Márquez Álvaro, nacido en Madrid en 1970, se licenció en Filosofía y Letras en la Universidad Autónoma de Madrid. Obtuvo el tercer premio en el concurso de poesía Coslada-Madrid, así como una señal de mérito en Il Convivio (Italia). Además de colaboraciones poéticas en diferentes periódicos y revistas, realiza actividades de lectura de poesía.

Gabriel Astey 


\title{
Poeta EN EL DF
}

\author{
Javier Márquez Álvaro
}

\section{VERDE}

Somnoliento, aún rezuma en mis pupilas la savia ingente de la curia mexicana, los soles que me arrullan, las lluvias que adolecen de nopales en terrazas que no cesan de enamorarse; transito taquerías henchidas de verdades, colores que se mezclan fieles con el olor que como lengua mueve conciencias.

Me tumban bicicletas rayadas en asfalto, mas el ruido que no cesa y la alfombra de las pieles no dejan de inculcarme la voz verde de la tierra.

Medito me alargo me escondo entre las sombras de unos árboles alados. 
De pronto una nieve, un flan, el pollo incandescente; los viajes de la vida resumidos en vidrio mexicano... No sé si duermo o me vence el sueño, de un rincón nace un sonido de trompeta de esqueleto, acordeones de cajeta y un tambor desvencijado.

No sé si bebo o me vence el duelo, paredes de tequila y cuadros de cerveza, las luces de afuera me toman por dios o por la bestia, pero en el fondo creo que en el quicio de la cama me esperan las estrellas...

No sé si como o me vence la gula, pero pastores de pizza me persiguen por ríos de aguacate y jitomate.

Al final es solo el verde de mis ojos, al final es solo vicio derretido, las batallas que se libran hacia adentro son más fuertes que el latir de los venados, los escollos que nacen como auroras se reprenden en camiones atestados de humildades... 


\section{BLANCO}

Guadalupe, buena virgen del amor y de los fieles... encomienda la vida a tus ojos soles, las verdades que nos duelen y se filtran por los poros, como fuentes que brotan de nuevo en el invierno...

La pureza

y las raíces que me arranco desde adentro

requiebros

dunas

pendones de silencio...

Miro los montes, aquellos que nos vieron nacer de entre

terrones

sueño con el oro

entrego mis corceles

y espero

ansioso

misterioso

dulce a la vez que extraño...

Bebo los tequilas de la paz desmesurada

trago

y te veo colgando de la luz de tus iglesias

esperando la dicha que blanca y tierna te puebla... 


\section{RoJO}

De la sangre y los perdones, de batallas y aventones, del amor de las mujeres tomado como droga, así transcurre la vida en su colapso, así se tienen las manos como cuerdas...

Fino

suave

seda para un cuerpo que pecó de vanidades, grave estentóreo fusiles para una sangre que se tiñe de ilusiones... Me acerco a tu violencia me suena cierto eco me apuntas me disparas las balas de un país que te atrapa como cebo. 
CITAM Derechos Reservados.

La reproducción total o parcial de este artículo se podrá hacer si el ITAM otorga la autorización previamente por escrito. 


\section{EL AROMA DE LA COSTA \\ Max Román*}

La gran mayoría de los viajes de mi infancia y mi adolescencia fueron a la Costa Chica de Guerrero, específicamente entre Acapulco y Ometepec. Mi familia entera y yo íbamos metidos como felices sardinas en una Ichiban que mi abuelo compró a inicios de los noventa. Se volvió tradición de cada año hospedarnos en el pueblo costero de Marquelia y dormir en un pequeño hotel sobre la carretera federal. Desayunábamos a las 10 y comprábamos la comida de la tarde en el mercado local, con puestos de tablas de madera y piso de arena sólida, todo atestado de moscas a las que uno se acostumbraba en minutos.

En los primeros viajes, recorrimos durante horas la carretera costera buscando el camino, muchas veces de tierra y arena, para llegar a las playas a las que nos invitaban los lugareños cada mañana. Una día nos recomendaron una playa a un kilómetro y medio por terracería, muy bella, pero ya manchada por la población hotelera y restaurantera. (A esa playa iríamos cada año, hasta dos veces, en enero y en julio, durante las vacaciones.)

La arena era negra, en parte por su origen volcánico y en parte por el aceite de las pocas lanchas que traían y llevaban turistas a pasear por la costa; sin embargo, extensos bancos de arena amarilla bajaban hasta las olas. Nosotros preferíamos bajar por esos bancos, aunque la

*Escritor. 
arena era tan caliente que nos quemábamos las plantas de los pies y no nos deteníamos hasta meterlos al agua.

Mi familia estacionaba la camioneta sobre el camino que nos llevaba a la playa, bajo la sombra de una casa que vimos crecer desde su construcción hasta que una familia vivió ahí feliz, dos años después de que el Estado intensificara la guerra en la región. Caminábamos unos cuantos metros desde la camioneta hasta las primeras palapas de la playa. Cargábamos bolsas con ropa de mis tías, comida, petates, un six de cervezas, y nos plantábamos bajo la misma palapa todos los años. A la señora que nos atendía no parecía afectarle el paso del tiempo, aparecía frente a nosotros como una figura eterna, inamovible en el color y textura de su piel.

(La descripción exacta y literaria de cada uno de los personajes anónimos en mis recuerdos es inútil; en cambio, el banco de imágenes de mi mente busca a una señora indígena o mestiza, costeña, con un tono de piel similar, con una estatura similar y el contorno de su cuerpo delgado y fino como una mecha quemada, y la atavía como alguna vez vi a mi bisabuela. Tomo la imagen de la madre de mi abuelo guerrerense, allí está, limpiándose las manos en un mandil, todo el residuo fresco de la masa de las tortillas o la sal de los pescados, el jugo del jitomate 102 rebanado.)

Antes de que todos corriéramos al agua a nadar como polluelos entre las manchas de aceite (más grandes cada año) y enormes trozos de madera (pequeñas selvas flotantes), nos bañábamos bajo una regadera en un cuartito de ladrillos de hormigón sin techo y con un escusado que solo podía activarse cuando le vaciabas una cubeta entera de agua.

Siempre preferí bañarme solo y quedarme unos minutos bajo el agua fría, que, por el calor y el mar salado, se sentía tibia y sabía muy dulce. El chorro de agua también cambiaba con el transcurso de los años. El primer año fue el de una regadera normal; el segundo, tenía la misma potencia, pero menor número de hilos de agua, y así disminuyeron hasta que solo quedaron varios hilos transparentes, pero más gruesos y ruidosos.

Me plantaba bajo la regadera y miraba al cielo. Entre el azul perpetuo (nunca vi un solo día nublado en todos mis años en Guerrero) y yo, 
había una frondosa palmera que se mecía con el fresco y salado viento. A las 11 de la mañana, los rayos se filtraban entre sus filosas palmas y un arcoíris se abría con el rocío de la regadera. Bajaba la mirada y enfrente podía ver, a través de los agujeros de los ladrillos, la extensión de pasto alto y los árboles que circundaban las habitaciones donde los turistas se hospedaban. (Más bien parecían cabañas comunales hechas de ladrillo rojo, muy poco ventiladas. Una vez nos instalamos en una de esas habitaciones, solo para probar; tomamos una habitación de la carretera al día siguiente.)

Tenía ante mí una panorámica completa del área habitacional y, en un extremo del jardín-patio, basura que se quemaba. Una enorme pila de materia carbonizada emitía tronidos y, tras cada uno de ellos, un ligero movimiento le daba una animación fugaz, como si un animal quisiera salir escarbando de ahí e instantáneamente se arrepintiera y se quedara quieto. Había pequeñas llamas vivas dispersas sobre el montón oscuro de ramas, envolturas de todos los materiales, recipientes, materia orgánica en putrefacción, telas viejas y, claramente visible, un zapato tenis: todo el deshecho que una familia podía tener en su casa. La columna de humo negro se elevaba, arremolinaba, giraba y se imponía por entre varias palmeras con menos fuerza que cuando comenzó el fuego, pero aún era formidable.

Mi hermano tocó la puerta de madera vieja y mal pintada: era su turno y yo me apresuré. Inundó el baño un aroma dulce y tostado, oscuro pero sutil, que sería característico de todos mis viajes a Guerrero. Esa noche salí solo del hotel a comer tacos en el puesto de la esquina, y ahí estaba ese olor; también estaba en la carretera al abrir la ventanilla, entre las hojas de los bosques de palmeras plantados en líneas y cuadrículas, en la costera Miguel Alemán de Acapulco, en la orilla y en las aguas de la laguna de Chautengo, incluso en el atrio de la iglesia de Ometepec, de donde era mi abuelo. Guerrero para mí siempre ha olido y olerá a la carbonización de todos los elementos humanos, permanentes o desechables. A mis recuerdos.

Hace mucho tiempo que no he regresado a Guerrero pero, en muy raras ocasiones, el aroma viene a mí, a mi ciudad, traído por el viento. Cargo una gran nostalgia por el mar y por el olor a quemado de Guerrero. 
La tarde en que recordé el aroma de la costa, el gran funcionario salió a dar una conferencia de prensa, en la que con voz apagada y forzada tristeza mostró a los medios las imágenes de los rescoldos de una quema inmensa, como la que vi muchas veces en las hierbas de la costa. Ante su silencio, ante las imágenes silenciosas que los peritos filmaron, hizo falta alguna versión del Magnificat (Arvo Pärt o Caleb Burhans) y convertirla, junto con los testimonios de los perpetradores de la pira, en un fragmento del más fino documental de Herzog. Me pregunté a qué olería ese Guerrero.

Durante esos días, leí la novela Sin destino, de Imre Kertész, donde encontré este fragmento:

Entonces percibimos claramente aquel olor difícil de definir que ya nos había llamado la atención: era un olor dulzón y pegajoso, con deje a residuo químico ya conocido, un olor tan intenso que casi me hizo devolver el pan. No nos fue difícil descubrir que procedía de una chimenea situada a nuestra izquierda, en la dirección del camino asfaltado, pero mucho más lejos. Parecía la chimenea de una fábrica y, según la respuesta que nos había dado alguno de los soldados, era en realidad la chimenea de una fábrica de cuero. Yo asocié aquel olor con el de otra fábrica de cuero por la que pasábamos algún domingo, cuando iba con mi padre a ver un partido de futbol en el estadio de Ujpest.

Las imágenes se mezclaron en mi cabeza: Auschwitz, Marquelia, Guerrero. El hombre con buena memoria nunca recuerda nada porque jamás olvida nada, dijo Beckett de Proust. Y la nariz de Proust, hasta donde sabemos, nunca lo engañó, sino que fue uno de sus instrumentos principales para recuperar el tiempo perdido. Para mí, el dulce aroma de la costa siempre ha estado ahí, siempre presente en mi nariz, imposible de recordar a voluntad, al igual que el olor de las personas.

Me siento identificado con Kertész. Pero, ¿lo que yo olí era la muerte? Sí, pero no la de los muertos de Kertész o Guerrero, sino la muerte de todas las cosas, de la materia, identificable o no. Ni Kertész ni yo supimos identificar lo que sucedía en ese momento, debido a nuestra ingenuidad y juventud. Nuestra nostalgia por Guerrero y Auschwitz huele 
dulce. Vi las copas de las palmeras lo suficiente como para tenerlas bien grabadas en mis recuerdos, igual que aquel zapato tenis que dejó de ser blanco para chamuscarse y derretirse; Kertész vería sin duda en esa playa una chimenea debajo de una columna de humo; seguramente para otros habrá más columnas de humo, más chimeneas, más objetos apilados e incinerados, más vacío carbonizado y recuerdos arrastrándose en el viento hacia el cielo.

Todos miramos en nuestros recuerdos elevarse algo al cielo. Muchas veces tengo miedo de que los recuerdos me engañen y encontrarme con la verdad de que era la palmera la que se quemaba, toda la playa en llamas, y que la pila de basura era el paraíso tropical; que no hubo estudiantes ni judíos, ni la fragilidad de todas las cosas, sino que el mundo se va entre las llamas que carbonizan incluso la tierra, lo humano que se quema, porque cuando nosotros desaparezcamos solo quedará el mar y el vacío.

Diciembre, 22 y 2014.

Enero, 7 y 2015. 
CITAM Derechos Reservados.

La reproducción total o parcial de este artículo se podrá hacer si el ITAM otorga la autorización previamente por escrito. 


\section{LA NIÑA QUE APRENDIÓ: ANÁLISIS LITERARIO-ÉTICO DE UN CUENTO DE IGNACIO PADILLA Cecilia Galaviz Álvarez*}

RESUMEN: El presente texto es un análisis crítico literario de un cuento de Ignacio Padilla. Se indaga la relación entre la literatura y la filosofia, especialmente la ética. El cuento invita a reflexionar acerca de los cambios civilizatorios obligados sobre ciertos seres humanos y el resultado de deshumanización que acontece cuando no se toman en cuenta las diferencias, que pueden ser educativas, culturales o físicas.

PALABRAS ClAVE: diferencia, subalterno, conciencia moral, culpa, lenguaje.
THE GIRL WHO LEARNED: AN ETHICAL-LITERARY ANALYSIS OF AN IGNACIO PADILLA'S STORY

ABSTRACT: This article is a literary critical analysis of an Ignacio Padilla's story. We will investigate the relationship between literature and philosophy, particularly ethics. This story invites us to reflect on the civilizing changes imposed on some human beings and the resulting dehumanization when their differences are not taken into account.

KEYWORDS: difference, subordinate, moral conscience, blame, language.

* Departamento Académico de Estudios Generales, ITAM. 


\section{LA NIÑA QUE APRENDIÓ: ANÁLISIS LITERARIO-ÉTICO DE UN CUENTO DE IGNACIO PADILLA}

\section{Introducción}

V argas Llosa, en su discurso de aceptación del premio Nobel de Literatura, afirma que la literatura nos permite vivir situaciones distintas a las de nuestra cotidianidad. Nos permite - dice - ver el mundo de distinta manera, saber que el mundo, tal cual es, es imperfecto y no muestra la trascendencia. Gracias a la ficción, nos adentramos en personajes que nunca seremos pero que, paulatinamente, con cada lectura, van dándonos nuevas perspectivas y formando nuestra personalidad, así como nuestro juicio crítico que hará que no seamos fácilmente manipulables por ideologías o políticos. Somos un poco mejores por los libros que hemos leído. ${ }^{1}$

Los sucesos que la literatura narra y que leemos con deleite permiten apreciarlos como si fuera al lector a quien ocurren. Obliga - afirma Martha Nussbaum - a enfrentarlos desde la ética, es decir, desde una situación de compromiso, porque los asuntos que se plantean, al apropiárselos el lector, no pueden dejarlo indiferente. Será el lector, desde su perspectiva, quien habrá de afrontarlos. ${ }^{2}$

${ }^{1}$ Mario Vargas Llosa, "Discurso de aceptación del premio Nobel de Literatura de 2010", en $<$ https://www.nobelprize.org/nobel_prizes/literature/.../vargas_llosa-lecture_sp.pdf $>$.

${ }^{2}$ Martha Nussbaum, El cultivo de la humanidad, 2005, Barcelona, Paidós Ibérica. 
El cuento de Ignacio Padilla "Miranda de Chalons" será la piedra alrededor de la cual aprovecharé lo dicho por Vargas Llosa y por Nussbaum y también revisaré la tesis de G. C. Spivak, ${ }^{3}$ que es una conocida crítica literaria que ha hecho estudios profundos a propósito del subalterno. Analizaré los conflictos morales que justificaron las conductas de los distintos personajes, los que desembocaron en la creación del personaje que da nombre al cuento, las críticas filosóficas que se podrían hacer a tales conflictos y, finalmente, del conocimiento que la ficción nos ha dado. Todo esto desde la perspectiva de Joan Carles Mèlich, filósofo catalán contemporáneo.

El cuento pertenece al libro $E l$ androide y las quimeras. Padilla divide sus cuentos, me parece, precisamente según si hacen alusión al androide o a las quimeras. Si recordamos que la quimera es un monstruo formado por tres animales distintos, veremos cómo el personaje de Miranda de Chalons acabará por ser una quimera.

El cuento tiene un narrador que sabe todo lo que sucede y que, además, es protagonista.

${ }^{3}$ G. C. Spivak, "Can the subaltern speak?" Este título fue cambiado por la autora por el de "History", cuando lo incluyó en A critique of poscolonial reason. Las referencias de este texto serán a partir de la traducción al español de Sebastián Patiño y Gabriel Astey en Textos de teoría y crítica literarias (del formalismo a los estudios poscoloniales), 2003, México, Universidad de la Habana y UAM Iztapalapa, Selección y apuntes introductorios de Nara Araújo y Teresa Delgado.
Narra la historia de dos estudiosos del lenguaje en niños salvajes y primates. Uno de ellos conoce a una niña salvaje que ha sido rescatada de los bosques de Champaigne y ha sido insertada de nuevo en la civilización. Él es M. La Condamine. El otro estudioso, que será el narrador, conoce la historia solo por lo que le han contado y por una pequeña biografía que ha leído acerca de la niña. Este personaje siente una gran emoción y entusiasmo por conocerla.

El narrador cuenta que un día deciden visitar a la niña, que ahora es una mujer de nombre Mademoiselle Le Blanc. Al conocerla, la impresión del narrador es de sobrecogimiento. La mujer vive en un edificio oscuro, en una buhardilla pulcra, pero no acogedora, un lugar que muestra el carácter obsesivo de quien la habita. Una mujer envejecida prematuramente, obesa y desdentada. Se sostiene por la caridad y por la venta de los libros de su biografía.

Por lo que observa el narrador, la mujer cuenta su historia de memoria, pero sin sentimientos, tratando solo de repetir lo que su biógrafa, M. Hacquet, ha escrito de ella. Narra sus pocos recuerdos de infancia, cómo fue raptada, cómo sobrevivió a un naufragio y vivió en los bosques de Francia con una compañera, una niñita negra. Esta situación, sin embargo, no es la peor parte. M. Le Blanc muestra un resentimiento, un malestar que el narrador, 
de momento, no se puede explicar $y$, aunque la visita termina, el interés del narrador-protagonista se ha incrementado.

Después de esta visita, La Condamine enferma y el narrador anuncia que hará un viaje para conocer a las monjas que participaron en el proceso civilizatorio de la niña y para aclarar todas las dudas que tiene a propósito de lo que le parece que es el fracaso de ese proceso.

En ese viaje descubre cómo la niña cambió sus hábitos de vida y de alimentación, cómo fue cambiando su carácter agresivo por uno más dulce que incluso se tradujo en un deseo de vestir el hábito religioso. Este deseo fue, sin embargo, el detonador de todo su infortunio, pues, al cumplir los requisitos para ese fin, un confesor descubrió que, aparentemente, había cometido un crimen del que no se arrepentía y por ello le fue negado su deseo.

El narrador descubrirá más tarde que el crimen del que se acusa a la niña es haber matado a la niñita negra con la que vivió en el bosque. Había peleado con ella por un pedazo de espejo y, al parecer, la había golpeado y matado.

El protagonista del cuento se describe a sí mismo como un científico, estudioso del lenguaje en primates y niños salvajes; por esta razón, está muy interesado en que su amigo, $\mathrm{M}$. La Condamine, le presente a la niña salvaje de Chalons; en realidad, los dos amigos comparten este interés $y$, por eso, piensan que para ellos la niña es "oro molido" por los conocimientos que pudieran obtener.

A lo largo del cuento, el protagonista describe, con lujo de detalles, primero, su encuentro con la niña (ahora una mujer), y, después, las impresiones que ese encuentro ha dejado en él. En este sentido, el protagonista va siendo más afectuoso en su narración, no solo con su amigo La Condamine, quien se enferma después de su visita a Memmie (que es el nombre cariñoso que el propio La Condamine utiliza para llamar a la que fue niña salvaje de Chalons), sino que también abriga sentimientos de afecto hacia Memmie, que se muestra a lo largo de todo el cuento. Todo esto lo lleva a narrar con un lenguaje no científico, sino personal.

La intuición del narrador-protagonista le hace saber que algo falta en la historia que cuenta Memmie y en lo que su amigo le ha dicho, por lo que decide hacer ese viaje al lugar donde vivió la niña para saber más y resolver sus dudas.

El viaje del protagonista al convento de las monjas que cuidaron a Memmie resulta ser desolador. El protagonista descubre que Memmie fue rechazada para la vida religiosa porque el sacerdote que la confesó juzgó que eran "muchos sus pecados y nulo su arrepentimiento" y las monjas, que decían quererla, no la defendieron. Los sentimientos del prota- 
gonista se desencadenan. Se siente agraviado por el maltrato a la niña, se siente traicionado por su amigo, que no le dijo la verdad, y se siente tan responsable como los "benefactores" por el fracaso del experimento de la niña de Chalons.

En sus reflexiones científicas, el protagonista se pregunta si fue el lenguaje recién aprendido lo que le dio a Memmie la conciencia de culpa, la idea de que tenía una deuda impagable hacia sus "benefactores" y hacia la sociedad, y lo que la convirtió en una mujer triste, melancólica, llena de remordimientos y de rencor. Además, plantea la importancia del lenguaje para el pensamiento, pues con el lenguaje interpretamos la realidad en la que nos movemos.

El protagonista logra con sus descripciones hacernos saber tanto sus sentimientos como los de los demás personajes.

Joan Carles Mèlich puede apoyar este sentimiento en el narrador, pues también a él le resulta muy importante el lenguaje para la interpretación del mundo en que vivimos. Propone una ética de la compasión que acompañe, que no juzgue, y que tenga como guía, precisamente, la finitud del ser humano. Mèlich sostiene una ética fundada en la literatura, en la narrativa, y esto le dará la posibilidad de determinarla desde lo que él llama "una postura de adverbios", es decir, que la ética se mida según el cómo, el cuándo y el dónde y no sobre principios absolutos, impersonales.

Diría Mèlich con respecto al trato que la niña recibió, que no había habido para ella una palabra ética: "La ética es posible si la relación de alteridad no es simplemente una relación de diferencia con la palabra del otro [...] la palabra deferente, la palabra ética es hospitalaria, acogedora". ${ }^{4}$

Por otra parte, La Condamine es el personaje que acompaña al protagonista-narrador a lo largo de todo el cuento. Al principio, el lector tiene la impresión de que es un personaje secundario, que solo sirve para presentarnos a la niña salvaje de Chalons. Pero pronto descubrimos que su papel es muy importante en la historia; no solo conoció a la niña y sus vicisitudes, sino que ha formado parte de su vida, y el narrador descubrirá que, hasta cierto punto, ha sido el orquestador de su situación actual, puesto que el sitio en donde la mujer vive fue conseguido por La Condamine y fue él quien descubrió la condición en que fue encontrada la compañera de la niña, y este conocimiento fue fundamental para el destino de la actual Memmie Le Blanc.

La Condamine acompaña al protagonista en su primer encuentro con Memmie, pero después de esa visita, La Condamine, como hemos dicho,

${ }^{4}$ Joan Carles Mèlich, Filosofía de la finitud, 2002, Barcelona, Herder, p. 22. 
enferma, y esto hará que el narrador emprenda un viaje solo, para desvelar las dudas que han surgido en su mente desde ese primer encuentro. "-Vaya, pues, querido Burnett —me dijo con un hilo de voz-. Recuerde sólo que no está usted para salvar ni condenar a nadie". 5

La Condamine resulta ser un personaje amoroso, amigo incondicional del narrador y protector incansable de la niña salvaje. Quizá precisamente por eso, por amor a ambos, oculta al narrador la última parte de la historia. Pero, al mismo tiempo, consiente en el viaje del narrador. "Me bastó mirar su rostro para saber que La Condamine había estado aguardando mi regreso, ya no solo como el amigo que aguarda una charla cómplice, sino como el padre que ha dejado partir a un hijo a un viaje peligroso aunque necesario para forjarle el carácter". ${ }^{6}$

La Condamine se somete al escrutinio del narrador, a su indignación, a sus críticas, a sus ironías; pero como el guía que lo sabe todo, espera con paciencia el reclamo. Él es semejante a Tiresias, el profeta ciego de Sófocles, aquel que sabe la verdad y es críptico para decirla. Él es el primero en conocer la falta que se le imputa a la niña, pero no la juzga, no es él quien marca su destino, mas,

${ }^{5}$ Ignacio Padilla, El androide y las quimeras, 2008, México, Páginas de Espuma, p. 96.

${ }^{6}$ Ibid., p. 98. cuando esto sucede, la acoge, no la abandona. Es él quien revela al narrador la última verdad sobre Memmie y es él quien comparte la culpa con el narrador y con todos los "benefactores" por este acto fallido de "humanización" de una pobre mujer.

La niña salvaje ha tenido una infancia llena de conflictos y desgracias. Cuando el protagonista la conoce, procura descubrir sus más antiguos recuerdos, pues, al hablar con ella, Memmie solo parece repetir de memoria la biografía que escribió Madame Hacquet: "el testimonio de Memmie Le Blanc sería una calca del relato que su biógrafa habría escrito y fijado para ella. Por un instante me aterró la idea de que esa curiosa inversión hubiera agotado sin remedio la memoria de la muchacha". ${ }^{7}$ Esta biografía había dado cierta fama a la niña salvaje, pero, como en la mayoría de estos casos, el interés de un público curioso desapareció paulatinamente. La autora daba cuenta del encuentro de la chica en los bosques franceses y de cómo el Vizconde d'Epinoy la había protegido y había encargado para su cuidado y educación a las hermanas del Couvent de Regents.

Mademoiselle Le Blanc recordaba vagamente que había sido raptada por traficantes de esclavos que la habían pintado de negro para poder venderla pues, aparentemente, la tenían que transformar en algo distinto

\footnotetext{
${ }^{7}$ Ibid., p. 94.
} 
a lo que era. Hubo un naufragio del que ella y una pequeña compañera negra lograron salvarse y llegar hasta las costas de Francia. Ahí, en el bosque, aprendieron el lenguaje de los pájaros para poder comunicarse. "Me dijo cómo nadaron hasta las costas de Francia y cómo en sus bosques aprendieron a comunicarse con ademanes, a imitar el trino de los pájaros y a alimentarse de ranas, conejos e insectos". 8 Después, cuenta que peleó con su compañera por un pedazo de espejo "y de cómo se separaron luego de que Memmie abriese una profunda herida en la cabeza de su compañera de fatigas". ${ }^{9}$

La niña fue encontrada cuando tenía alrededor de doce años. Entonces fue educada, se le enseñó a hablar en francés y fue transformada según un modelo de civilización; se le exigió que dejara sus costumbres de nadar y trepar a los árboles. Se le cambió la dieta, lo que provocó que se le cayeran los dientes, y se logró un carácter dulce para ella.

Me atrevo a pensar que, quizás, el autor de nuestro cuento haya pensado en la dominación que la lengua francesa ha ejercido sobre una gran población de África, aun ahora que se habla de poscolonialismo, y de cómo la cultura francesa, junto con la lengua, ha permeado a esos pueblos, pretendiendo ser única.

${ }^{8}$ Ibid., p. 93.

${ }^{9}$ Ibid., p. 94.
G. C. Spivak plantea cómo el mundo está dividido entre los que mandan y los que obedecen; planteamiento que no es nuevo, pero que aborda el sometimiento de los que obedecen hasta dejarlos sin capacidad de expresión. Spivak piensa en la mujer que, como en su país, resulta transparente. "Sí, en el contexto de la producción colonial, el subalterno no tiene historia y no puede hablar, el subalterno como femenino está aún más profundamente en la sombra". ${ }^{10}$ Este es un elemento que podemos observar en Memmie. No afirmo que sea estrictamente un subalterno, pero sí que es tratada de manera que alguien más decide su vida y su futuro. "Para el (sin determinación de género) verdadero grupo subalterno, cuya identidad es su diferencia, no hay sujeto subalterno irrepresentable que pueda conocer y hablar por sí mismo". ${ }^{11}$ A ella no se le permitió decidir, opinar sobre su vida, ella no tenía voz; pero al tiempo ella intuyó que era "diferente". Nació en ella una conciencia de esa diferencia aunque no pudiera explicarla o comprenderla del todo y en ella dominaba "la angustia de esa pobre mujer que, para su mal, era plenamente capaz de reconocer lo que la hacía diferente del prójimo y la manera en que la vida la había incapacitado para ser una persona común". ${ }^{12}$

\footnotetext{
${ }^{10}$ G. C. Spivak, op.cit., p. 787.

${ }^{11}$ Ibid., p. 786.

${ }^{12}$ Padilla, op. cit., p. 92
} 
Como vimos, el interés original del narrador era científico. Así, descubre que el lenguaje ha provocado un importante cambio en la personalidad de Memmie: "percibí en la actitud de Memmie un importante matiz [...] algo había ocurrido en ella a medida que el lenguaje había ablandado los meandros más oscuros de su conciencia". ${ }^{13}$ Con el paso del tiempo, Memmie había adquirido conciencia de su situación. El narrador explica que todo niño salvaje tendrá siempre una malformación, pero la malformación de Memmie era de índole moral: ella había descubierto que nunca sería normal, que era un producto híbrido y falso de la civilización, que tenía una deuda impagable con sus benefactores, pero que ahora estaba sola y, abandonada, "y tanto, que ahora le era imposible deslindar su humanidad de su melancolía, una congoja de proporciones bíblicas que le emponzoñaba cotidianamente el alma como si la hermosa cesta del lenguaje hubiese encerrado para ella solo un áspid furioso". ${ }^{14}$

Lo cierto es que la acción civilizadora, que quisieron llamar "humanizadora", solo llevó a Memmie a la soledad y al sufrimiento, a convertirse en una historia desafortunada, "la obra trunca de un destino veleidoso". ${ }^{15}$

\footnotetext{
${ }^{13}$ Ibid., p. 95.

${ }^{14}$ Loc. cit.

${ }^{15}$ Ibid., p. 91.
}

La consecuencia de todo este proceso fue que ella quiso vestir los hábitos, pero su confesor decidió que eran muchos sus pecados (de los que no se arrepentía) y se truncó su deseo. Memmie se resignó a la negativa e inmediatamente empezó a decaer, hasta que "acabó por convertirse en una suerte de alma en pena a la que nadie sabía cómo tratar". ${ }^{16}$

En continuidad con el pensamiento de Mèlich, quienes protegieron a la niña siguieron patrones morales preestablecidos para ayudarla, pero esto no fue suficiente, porque cuando el interés o el dinero se acabaron, la niña quedó abandonada a su suerte, y porque, al final, solo se veía una diferencia, una desigualdad. Un principio ético basado en la literatura y no en la metafísica hubiera empezado por reconocer la finitud y la precariedad de ese ser humano, su ambigüedad. No se puede pensar que no prevaleciese nada de lo anterior a la recepción de "la cultura": lo que se ha sido y se ha vivido no puede borrarse por completo solo porque se recibe un nuevo aprendizaje.

Después de ese rechazo, el ánimo y la salud de Memmie decayeron y, probablemente, en la soledad fue sintiendo una culpa que hasta ese momento le era desconocida, pero que surgió en sus nuevas circunstancias. Esta toma de conciencia la convirtió en "un rencor viviente", en "una alma

${ }^{16}$ Ibid., p. 100. 
en pena". Es posible que sintiera remordimientos por un hecho de su vida pasada que nunca supo que era malo, pero luego, al cambiar sus circunstancias, se alteró la perspectiva de su propia vida, lo que generó en ella un enorme sentimiento de culpa.

El narrador parece creer que fue el lenguaje, el idioma francés que Memmie ha aprendido, lo que favoreció su toma de conciencia sobre el bien y el mal, pues con este lenguaje Memmie reconoce nuevos sentimientos sobre sí misma y sobre lo que le rodea. Ella ha aceptado todos los cambios que se le han impuesto, y su vida y seguramente su percepción del mundo han cambiado para siempre.

Cuando el protagonista llega a visitarla, Memmie solo repite lo que le han enseñado, pero cuando es cuestionada sobre sus sentimientos al abandonar a su compañera en el bosque, algo salvaje se muestra en su reacción, en su mirada: ahora parece "un animal acorralado" y solo responde: "—Nada, señor. Entonces no sentí nada". ${ }^{17}$

Esa palabra, "entonces", nos hace saber que ha cambiado la percepción que tiene Memmie de sí misma. Quizás ahora piensa que "entonces" debió sentir algo, pena o soledad; es posible que antes no lo supiera, pero ahora lo sabe.

Lo cierto es que ella se sometió a la educación de sus benefactores $y$,

${ }^{17}$ Ibid., p. 94. según parece, nunca se cuestionó lo que le estaban haciendo. Este proceso civilizatorio la condujo a una conciencia moral, pero no sabemos si surgió con el proceso o si estaba ahí desde el principio, aunque dormida. Lo que sí sabemos es que ahora tiene sentimientos que no sabe definir sobre la confrontación con su "compañera de fatigas" por un trozo de espejo, en la que la otra niña resultó herida. Después sabremos que los benefactores piensan que ese golpe mató a la niña; creyeron, entonces, que Memmie había ocultado esta situación, que había mentido.

Memmie no sabe cómo defenderse o justificarse. Se toman decisiones sobre su vida y sobre su futuro tal como habían hecho antes. Jamás permitieron que tomara una decisión, que ejerciera alguna libertad sobre su propia existencia y la condenaron a una vida miserable e incomprensible para ella, que solo la condujo a sentirse también miserable, ajena a todo $\mathrm{y}$, a la vez, aferrada a un entorno que la sometía pero que ella procuraba mantener impecable, como si tuviera miedo de que, al modificarlo, fuera a derrumbarse con él.

¿Memmie es igual a los demás?, ¿no es una realidad que es una niña - es decir, mujer y corta de edadsalvaje y que había quedado a merced de los otros? Alguien más habló por ella, alguien más decidió lo que 
le convenía; ¿hubiera podido decir qué quería? No, no solo porque no tenía el lenguaje adecuado, sino porque tampoco tenía una condición para hacerse oír. Es lo que Spivak llama "subalterno". Memmie no tiene voz, no puede hablar y, aunque tuviera el lenguaje adecuado, nadie la escucharía porque, a la vista de los demás, no sabe lo que le conviene porque no entiende su situación. No la ven como a un ser humano igual a los demás; en realidad, es inferior, es solo un "subalterno".

El lenguaje debió abrir a la protagonista las puertas a la cultura; debió ser el elemento que permitiera a la niña expresar sus deseos, sus pensamientos. Sí, se le dio el lenguaje pero, luego, se le prohibió el habla como expresión de su interior. "Gracias al lenguaje, Marie-Angelique Le Blanc se había convertido en un rencor vivo, en la encarnación misma de la culpa por un acto que ni siquiera estaba segura de haber cometido, una falta que se había transformado en pecado cuando su memoria al fin pudo nombrarla con todas sus letras." 18

El lenguaje dio nombre a las acciones de Memmie siguiendo parámetros occidentales y le dio la capacidad de reconocer su propia vulnerabilidad como un ser humano cuyo único conocimiento era cómo sobrevivir en un mundo inhóspito... como lo hace cualquier animal. La realidad de la niña pudo haber marcado la pauta para el aprendizaje que debió recibir.

La niña salvaje no se convirtió en Marie-Angelique Le Blanc. Fue obligada a usar un traje que le quedaba mal; pero no solo eso: en ese traje había alfileres con nombre de culpa que le hicieron daño, porque la niña no los pudo comprender del todo y porque nunca desaparecerían. Fueron sufrimientos y culpas que antes no conocía y que, tal vez, habrían podido evitarse si los acercamientos, sobre todo de los moralistas, del confesor y de la madre superiora del convento, hubieran sido más generosos y hubieran aceptado la condición finita de la niña, su situación concreta y la diferencia que realmente existía entre su vida y la realidad externa, que no dejaría de existir solo porque le cambiaron el vestido, la comida y las actividades cotidianas. Esa diferencia que no vieron los protectores "civilizados", no fue reconocida y solo los llevó a la intolerancia y al abandono de Memmie; es decir, al olvido de su responsabilidad con la pequeña.

La niña tenía un lenguaje cuando fue encontrada, pero se determinó que no era el adecuado y, por ello, no fue escuchada. El lenguaje que le impusieron la marcó como culpable sin posibilidades de redención.

${ }^{18}$ Ibid., p. 98. 


\section{A PROPÓSITO DE LOS ANTECEDENTES DEL PENSAMIENTO POLÍTICO CUBANO Óscar Puig Corral*}

\section{REGARDING THE ORIGINS OF CUBAN POLITICAL THOUGHT IN THE CONSTITUTION OF GUÁIMARO (1869)}

RESUMEN: Pretender analizar hechos ocurridos hace más de 148 años es arriesgado, si no se tiene en cuenta el momento histórico concreto. El riesgo es mayor al ser los hechos en cuestión parte importante de la columna fundacional de la historia patria cubana. No solo se analizan los primeros días de la gesta independentista; aun más importante, se intenta arrojar luz sobre la necesidad de crear un cuerpo armónico con forma de ley que uniera con un objetivo común a los patriotas cubanos. Curioso proceso este que iba en contrario al de la mayoría, primero una Constitución política que fijara los derroteros insulares durante la contienda; luego, se pensaba en cómo ganar la guerra contra España. Fue la Constitución de Guáimaro, nombre que tomó del poblado dónde se llevó a cabo la Asamblea Constituyente. Hacemos especial énfasis en la influencia de la Constitución de Cádiz y en la figura ilustre del presbítero Félix Varela como primer impulsor de las ideas sobre el constitucionalismo en Cuba.

Palabras Clave: Cuba, Asamblea Constituyente, constitucionalismo, Ilustración, revolución.
ABSTRACT: Any attempt to interpret the events that happened 148 years ago can be very risky if one does not consider the historic context. This risk is even greater since these particular events are foundational to Cuban history. We will not only analyze the first days of the independence movement but more importantly, we will shed light on the need of a cohesive structure shaped by a law that unified the Cuban patriots. It was a very unusual process indeed, in that it aimed at establishing first a Constitution to regulate the Island's course during the war, and only then turning its attention to defeating Spain. This "Constitution of Guáimaro" was named after the town which brought about the Constitutional Assembly. We will emphasize the influence of the Cadiz Constitution and the celebrated priest, Felix Varela, as the first promoter of constitutional ideas in Cuba.

KEYwORDS: Cuba, Constitutional Assembly, constitutionalism, Enlightenment, revolution.

\footnotetext{
* Universidad de Oriente, Santiago de Cuba.
} 


\author{
A PROPÓSITO DE \\ LOS ANTECEDENTES \\ DEL PENSAMIENTO \\ POLÍTICO CUBANO
}

Ala

la hora de hacer recuentos, siempre buscamos palabras o frases grandilocuentes. Cuando se trata de recuentos sobre hechos históricos, que incluso forman parte de la historia y el orgullo nacional, siempre quisiéramos ser exactos, dignos, honestos. En este caso el recuento es necesario, casi imprescindible. Se trata de retroceder en el tiempo 148 años y aterrizar en la manigua insurrecta, que confusa y corajuda, se debatía entre sacudirse a España de la espalda y la perentoria necesidad de darse un orden, un mapa, una raíz que la fijara definitivamente a la historia viva de la Patria. Eso fue la Constitución de Guáimaro. Alejados de cuestionamientos doctrinales, que no harían más que ahondar sobre lo ya ahondado, nos proponemos exponer nuestras ideas sobre los proce- sos materiales que llevaron a los jefes mambises a pensar en términos constitucionalistas y republicanos. Hablaremos, además, sobre los antecedentes directos e indirectos de esas ideas, basados en pensamientos fundadores de la misma nación cubana, que constituyen glorias de nuestro pensamiento patrio. En Guáimaro, pueblo liberado en noviembre de 1868, se fijaron los derroteros políticos y militares de la Revolución insurrecta. José Martí, con su egregio verbo, escribió: "Estaba Guáimaro más que nunca hermosa. Era el pueblo señorial como familia en fiesta. Venían el Oriente, y el Centro, y las Villas al abrazo de los fundadores". ${ }^{1}$

${ }^{1}$ José Martí, Obras completas, 1975, La Habana, Editorial de Ciencias Sociales, t. 4, p. 383. 
No es para nada ocioso recordar que el incidente que acabó de convencer a los jefes insurrectos de la urgencia de aprobar una Constitución, fue la autoproclamación de Donato Mármol, en enero de 1869, como dictador supremo de la revolución, ignorando incluso a Carlos Manuel de Céspedes y aconsejado entre otros por Leopoldo Arteaga, Pío Rosado, Manuel de Jesús Peña y por su polémico primo Eduardo Mármol. Supuestamente, el motivo fue que estos sediciosos no apreciaban dotes de conducción militar ni en Céspedes ni en Francisco Vicente Aguilera para llevar adelante la naciente revolución insurrecta. Por supuesto, lo de Donato Mármol y sus seguidores no fue más que una intentona fugaz, aunque extremadamente peligrosa. Luego, en una acalorada reunión en Tacajó, Mármol depuso sus intenciones y reconoció la autoridad superior de Céspedes, con la oportuna y sabia mediación de Francisco Vicente Aguilera. En esta reunión se acordó dotar de institucionalización al proceso revolucionario, dejando para después la elección de diputados con el rigor necesario para una Asamblea Constituyente. Esta tentativa sedicionista fue la principal razón, pero también subyacía el miedo a que el campo insurrecto fuera pasto de la espuela y el machete de caudillos militares, lo cual repetiría lo que había estado ocurriendo en otras partes de América Latina.
En una sesión previa a la convención, se reunieron Céspedes como "jefe del gobierno provisional del Departamento Oriental”; Miguel Gerónimo Gutiérrez, Eduardo Machado, Antonio Lorda, Tranquilino Valdés y Arcadio García, representantes de Villaclara; Honorato del Castillo, de Sancti Spíritus; Antonio Alcalá y Jesús Rodríguez, de Holguín; y Salvador Cisneros Betancourt, Francisco Sánchez Betancourt, Ignacio Agramonte y Miguel Betancourt, del Camagüey. Además, se incluyó en la delegación camagüeyana al joven pensador habanero Antonio Zambrana. ${ }^{2}$

Los diputados del Camagüey y Las Villas fueron en extremo insistentes en marcar el rumbo de la revolución mediante un texto constitucional. Estuvieron de acuerdo los orientales, que se sentían dispuestos a redactar algo más provisional, no con carácter de Carta Magna, sino que simplemente le diera curso viable a las necesidades militares de la guerra. Además, fue la misma razón por la cual, aparte de que había mayoría de diputados villareños y camagüeyanos, Céspedes prácticamente no se opuso a ninguna de las disposiciones redactadas por Ignacio Agramonte y Antonio Zambrana, las que luego, en algunos casos al ser malentendidas y

${ }^{2}$ Rolando Rodríguez García, "La Asamblea y la Cámara de Guáimaro", en Raíces en el tiempo, 2009, La Habana, Editorial de Ciencias Sociales, p. 101. 
en otros, por ser aplicadas demasiado al pie de la letra, pusieron en riesgo la continuidad y el éxito de la revolución independentista. Sobre la actitud de Céspedes, Martí escribió: "Céspedes se plegó a la forma (republicana) del Centro. No la creía conveniente; pero creía inconveniente las disensiones. Sacrificaba su amor propio; 10 que nadie sacrifica". ${ }^{3}$

Resumiendo los resultados de la asamblea de Guáimaro, el investigador Rolando Rodríguez expone:

La asamblea logró un objetivo esencial en la revolución que la vuelve imperecedera: estableció la unificación de los grupos insurgentes, lo que permitiría dar un paso rotundo hacia la formación de la nación y de la república cubanas; pero a decir verdad, no obtuvo su unidad en las concepciones organizativas y métodos para enfrentar la lucha. En definitiva, en ella nadie convenció a nadie. Aparte de aquella unificación de los grupos; de un lado, los resultados fueron los que impuso la mayoría que formaban los camagüeyanos secundados por los villareños, $\mathrm{y}$, de otra, las cesiones que hizo el iniciador de la gesta en aras de la revolución. ${ }^{4}$

Ahora bien, ¿cómo entender que en la mente de aquellos hombres podía operar una idea que consideraban

${ }^{3}$ Martí, op. cit., t. 22, p. 235.

${ }^{4}$ Rodríguez García, op. cit., p. 103. de mayor importancia que incluso muchas decisiones militares de suma trascendencia que debían ser tomadas con urgencia, es decir, reunirse los representantes del pueblo de Cuba en armas y dotarse de una constitución? En esta interrogante encontramos el primer botón de muestra de lo novedoso de este proceso, porque la historia de los movimientos revolucionarios y de las luchas por la independencia en América demuestra que primero se ganaba la guerra y luego se hacía la Constitución. Ahí están para probarlo los hechos de la Guerra de Independencia Norteamericana y los movimientos independentistas de América Latina. En estos procesos hubo muchas declaraciones, muchos bandos militares, muchas proclamaciones, pero constitución en el sentido propio del término, solo después de haber tomado el poder político, una vez derrotado el enemigo de la metrópoli colonial.

De modo que no deja de ser paradójico que los mambises cubanos hayan decidido adoptar formas institucionales con el nombre de constitución, en momentos en que no era ni por asomo debido ni exigido para movimiento de independencia alguno. Pero lo que más asombro causa es que se mantuvieron fieles a su constitución y trataron de cumplir su mandato, en algunos casos demasiado al pie de la letra. Salvador Cisneros Betancourt, marqués de Santa 
Lucía, movido por la admiración y el fervor hacia el espíritu constitucional y el ideal republicano, llegó a decir que prefería perder la guerra antes que perder el respeto por la constitución. En cierta forma, esta idea del marqués prefigura lo que posteriormente escribió José Martí, que trataré de citar lo más fielmente posible: "el despotismo que podría sobrevenir en caso de una guerra de independencia de baja raíz y temibles fines y que tuviera como resultado la entronización en Cuba de una dictadura militar, sería peor que el despotismo político español", es decir, que el despotismo militar cubano sería peor que el despotismo de la metrópoli, y explica Martí sus razones diciendo que sería más difícil desarraigar la dictadura militar, estando en ese futuro hipotético legitimada por el éxito y la gloria alcanzados en el campo de batalla por esos caudillos militares a los que temió y combatió toda su vida. Martí escribió esto llevado de la mano por sus más profundas convicciones republicanas, y creo que sería conveniente estudiar sus ideas en torno a estos temas, sobre todo si caemos en cuenta de que es una de las facetas que menos se lee dentro de la abundante obra martiana. Céspedes escribió en su proclama:

No nos extravían rencores, no nos halagan ambiciones, solo queremos ser libres e iguales como hizo el Creador a todos los hombres. Nosotros consagramos estos dos venerables principios: nosotros creemos que todos los hombres somos iguales: amamos la tolerancia, el orden y la justicia en todas las materias; respetamos las vidas y propiedades de todos los ciudadanos pacíficos, aunque sean los mismos españoles, residentes en este territorio; admiramos el sufragio universal, que asegura la soberanía del pueblo; deseamos la emancipación, gradual y bajo indemnización, de la esclavitud; el libre cambio con las naciones amigas que usan de reciprocidad, la representación nacional para decretar las leyes e impuestos, y en general, demandamos la religiosa observancia de los derechos imprescriptibles del hombre, constituyéndonos en nación independiente, porque así cumple a la grandeza de nuestros futuros destinos, y porque es más seguros que bajo el cetro de España nunca gozaremos del franco ejercicio de nuestros derechos. ${ }^{5}$

Entonces, para entender de alguna manera los motivos y las razones que llevaron a los insurrectos cubanos a dotarse de una constitución a escasísimos meses del Grito de Yara, debemos hablar, aunque sea en forma

${ }^{5}$ Luis Miguel García Mora y Alejandro García Álvarez (coords.), "Manifiesto de la Junta Revolucionaria de la Isla de Cuba", en Textos clásicos de la historia de Cuba, 1999, Madrid, Fundación MAPFRE, p. 24. 
abreviada, de algunos hechos que contribuyeron a formar ese sentimiento republicano, constitucionalista y liberal, en el sentido que tenía en el siglo XIX y no en la actualidad, pues en aquellos años liberal era todo aquel que era amante y defensor apasionado de la libertad, mientras que, desafortunadamente, en la actualidad se usa para designar a una corriente de pensamiento económico, más que político. Y si se quiere una prueba, acudamos a Mariana Grajales, esa leona madre de leones, cuando delante de sus hijos y con el crucifijo en la mano ordenó: "de rodillas todos, padres e hijos, delante de Cristo, que fue el primer hombre liberal que vino al mundo". ${ }^{6}$ Volviendo a los hechos que condicionaron el afán constitucionalista mambí, podríamos situarlos en los primeros años del siglo XIX, cuando en Cuba ciertas personalidades comenzaban a promover, en muchos casos intencionadamente, un proceso de alguna manera similar al que se dio en Francia con la Ilustración, evidentemente a escala mucho menor, en un país alejado de la metrópoli occidental, pero tan rico que contribuyó en el siglo XIX con la nada despreciable cifra de entre el 65 y el $70 \%$ de los ingresos del Imperio español.

\footnotetext{
${ }^{6}$ Véase sobre este famoso juramento la Carta de María Cabrales dirigida a Francisco de Paula Coronado, fechada el 6 de mayo de 1897, en Papeles de Maceo, t. II, 1998, La Habana, Editorial de Ciencias Sociales, pp. 73-75.
}

En otras palabras, en ese siglo, España vivió de las riquezas de Cuba. Muchos cubanos se dieron cuenta de que las riquezas de la isla no debían ser para los peninsulares, sino para que las disfrutaran los cubanos.

La consecuencia fue que, hacia 1810, empezó a apreciarse en Cuba un fuerte movimiento de ideas que apuntaban a una reforma educativa, así como a un conjunto de medidas políticas que se expresaron en los primeros proyectos constitucionales elaborados en Cuba, impulsados también por los acontecimientos contemporáneos en España, que dieron lugar en 1812 a la promulgación de la primera constitución ${ }^{7}$ de España y también la primera de Cuba, pues fue el primer texto constitucional vigente en la isla. Esta constitución, con todas las limitaciones del caso, del poder de la monarquía española y de la religión católica, reconocía una amplia gama de derechos civiles y políticos, heredados por supuesto de las declaraciones francesa y norteamericana.

Esa época coincide con los dos años de vigencia de la Constitución de Cádiz en Cuba, de 1812 a 1814, cuando Fernando VII regresó de su exilio dorado en Francia e impuso a sangre y fuego la monarquía abso-

${ }^{7}$ Este texto constitucional también es conocido con el nombre popular de "la Pepa", por el hecho fortuito de haberse proclamado el 19 de marzo de 1812, día consagrado por el santoral católico a San José. 
luta. En Cuba, estos sucesos pasaron casi inadvertidos, y al explicarnos esa extraña situación, no encontramos otra respuesta que el cuidado que puso Fernando VII en no molestar en demasía a los terratenientes y poderosos plantadores cubanos, que no solo tenían poder económico, sino también poder político, aunque fuera de manera soterrada. En muchos casos, los hacendados criollos eran más ricos que muchos rancios aristócratas españoles, que tenían muchos títulos y mucho abolengo, pero poco oro en sus bolsas. No convenía causar muchos disgustos a los hombres ricos de la única posesión que España conservaba en América. Recuérdese que para esta fecha, la mayor parte de los movimientos independentistas americanos habían triunfado, con las consiguientes pérdidas millonarias para la corona española y la mancha para el orgullo ibérico.

En esta primera etapa, que va de 1814 a 1820, conocida como la "Edad Dorada" del reformismo, mientras España se ocupaba de intentar la reconquista de sus colonias perdidas, la isla gozó de una bonanza económica, por supuesto, para los grandes propietarios y explotadores esclavistas; ni pensar que para el pueblo haya habido mejoras económicas y mucho menos para la población esclava, que sostuvo sobre sus espaldas tal desarro1lo. Sin embargo, fue un marco propicio para que los autores cubanos, que en esa época luchaban para establecer un pensamiento político, filosófico y jurídico genuinamente nacional, tuvieran amplio margen para desplegar sus concepciones.

Corresponde mencionar en primerísimo lugar al padre Félix Varela, que por esos años llevó a cabo la primera y más importante reforma de la enseñanza filosófica en Cuba. Cuando cinco o seis años más tarde se verificó en España la segunda proclamación de la Constitución de Cádiz, con la aprobación, al menos formal, del rey, el padre Varela, impulsado por el obispo Espada, que fue el principal promotor de esta Ilustración cubana, ${ }^{8}$ amparado en su carácter de obispo y en el poder que tenía la Iglesia católica, se dio a la tarea de fundar la primera cátedra de Derecho constitucional (Derecho político se nombraba en esa época) que existió en Hispanoamérica. Esta fundación se basa en una disposición del gobierno liberal español en el llamado Trienio Liberal, ${ }^{9}$ por la que

${ }^{8}$ Juan José Díaz de Espada y Fernández de Landa era el nombre completo de este obispo español, que desde su consagración en la catedral habanera se dedicó a realizar acciones encaminadas a favorecer la cultura, la educación, el saneamiento y la moralización de la diócesis. Fue un intelectual de proyecciones clarísimas, con una preocupación constante por formar hombres de bien con amplios conocimientos. El obispo Espada estuvo acompañado de nombres tan ilustres en el ámbito intelectual cubano como Tomás Romay, José Agustín Caballero y el propio Félix Varela, entre otros.

${ }^{9}$ Periodo de la historia española entre 1820 y 1823 , cuyo nombre responde al paréntesis libe- 
se mandó que en cada ciudad española y en cada ciudad de los territorios ultramarinos se constituyera una plaza de la constitución y se fundara una cátedra de estudios constitucionales. El padre Varela se presentó al concurso de oposición y recibió en propiedad la docencia de la cátedra, que comenzó a impartir a principios de 1821. Todos los testimonios de la época coinciden en que se trató de un hecho inaudito y de un impacto extraordinario; personas colgadas de las ventanas hacían todo lo posible por entrar al salón de conferencias, completamente colmado. La mayoría escuchaba desde fuera, sin poder ver. Las conferencias dictadas por Varela habían sido un rotundo éxito. La formación religiosa permeó el iusnaturalismo de esos estudios de Derecho constitucional, y se afirmaba la posesión de derechos imprescriptibles, de los que ninguna nación podía hacer traslado o remoción, por ser superiores a la ley. Uno de los valores esenciales que movió a los mambises cubanos a plantearse el complejo problema de la constitución fue el de la igualdad de los hombres, sin distinciones de ninguna clase. Sobre este aspecto Varela decía:

El hombre libre que vive en una sociedad justa, no obedece sino a la ley;

ral y constitucionalista que abrió el rey absolutista Fernando VII. Es también conocido como Trienio Constitucional. mandarle invocando otro nombre es valerse de uno de los muchos prestigios de la tiranía, que solo producen su efecto en almas débiles. El hombre no manda a otro hombre; la ley los manda a todos [...] Uno de los resultados de la verdadera libertad es el derecho de igualdad, que quiere decir el derecho de que se aprecien sus perfecciones y méritos del mismo modo que otros iguales que se hayan en cualquier individuo, de manera que una acción no pierde por la persona que la ejecuta. ${ }^{10}$

Al valorar los resultados fenomenales que habían tenido las clases, el obispo Espada ordenó la publicación por primera vez en Cuba (y hasta donde se tiene noticia, en Hispanoamérica) del primer tratado de Derecho constitucional. Antes, habían circulado traducciones de Rousseau, de Montesquieu, etc. Ese primer tratado de Derecho constitucional escrito en español contenía las lecciones impartidas por el padre Varela y llevó el título de Observaciones sobre la Constitución Política de la Monarquía española. El libro solo fue reeditado en Cuba en 1944, y desde entonces esperamos por un editor osado y de finísimo olfato que nos regale esta maravillosa y aleccionadora lectura, que tiene un lugar cimero,

\footnotetext{
${ }^{10}$ Jorge Ibarra Cuesta, Varela el precursor. Un estudio de época, 2008, La Habana, Editorial de Ciencias Sociales, p. 61.
} 
aunque no muy conocido, entre los clásicos del pensamiento cubano.

A donde vamos llegando ya en nuestras ideas, es a que todo ese periodo de intensos debates, potenciados por la libertad de prensa, la igualdad jurídica y las concepciones individualistas de los principios de libertad, igualdad y propiedad, preceptos todos derivados de la letra de la Constitución de Cádiz, propició en Cuba la publicación de gran cantidad de periódicos, panfletos y folletos que defendían los ideales constitucionales y republicanos, la libertad, los derechos individuales, las garantías judiciales, etc. No hay duda de que gran parte de ese ímpetu constitucionalista se debe a la obra del padre Varela, pues pasaron por su aula José de la Luz y Caballero, José Antonio Saco, Nicolás Escobedo, Domingo del Monte, José María Heredia y una lista larga. Cada uno de estos hombres contribuyó, dentro de su ámbito de acción y de sus posibilidades reales, a conformar un ideal de nación cubana, pero de nación republicana, no monárquica; una nación de respeto y garantías para los derechos individuales. Varela, derivado de su éxito en las clases, fue electo diputado a las Cortes de Madrid, que luego se mudarían otra vez a Cádiz ante el avance de las tropas francesas que venían a reponer en el trono a Fernando VII, ${ }^{11}$

\footnotetext{
${ }^{11}$ Tras la celebración del Congreso de Verona (octubre-noviembre de 1822), los países miembros de la Santa Alianza: Francia, Rusia, Austria y Prusia,
}

y aunque no pudo regresar a Cuba, en suelo patrio quedaron sus principales discípulos. José de la Luz y Caballero dirigió la cátedra de Filosofía hasta que fue cerrada y luego fundó su propia escuela, gastando su dinero y minando su salud, donde tuvo entre sus discípulos a hombres de la talla de Perucho Figueredo, Ignacio Agramonte, Julio Sanguily, Antonio Zambrana, entre muchos otros. Años después, estos alumnos recordaban las palabras del ya viejo pedagogo: "para que Cuba sea libre, yo soy maestro de escuela". Muchos años más tarde, José Martí rememoraba que no había un hogar en Tampa y en Cayo Hueso donde no estuviera colgada, junto a la bandera cubana, una foto de Don Pepe, como cariñosamente llamaban los cubanos al maestro José de la Luz y Caballero.

El padre Varela sabía del alcance de sus prédicas; ya en el prólogo de su famoso Cartas a Elpidio anunciaba:

No creo haber ofendido a ninguna persona determinada, pero no ha

acordaron el envío de tropas para devolver el régimen absolutista en España. Esta invasión fue conocida como los Cien Mil Hijos de San Luis, en alusión al discurso del soberano francés Luis XVIII en el que invocó al "Dios de San Luis" y a la ayuda segura de "cien mil franceses". Estas tropas, mandadas por Luis Antonio de Borbón, duque de Angulema, cumplieron su objetivo sin encontrar apenas resistencia, y apoyados por una masa realista que ansiaba la vuelta absolutista, instalaron nuevamente a Fernando VII en el trono. 
sido posible prescindir de dar algunos palos a ciertas clases. Quisiera que hubieran sido más flojos; pero estoy hecho a dar de recio, y se me va la mano $[\ldots]$ Preveo que este avechucho puede acarrearme algunos enemigos, pero ya es familia a cuyo trato me he habituado, pues hace tiempo que estoy como el yunque, siempre bajo el martillo. ${ }^{12}$

Para concluir, consideramos que no es aventurado decir que la obra filosófica, jurídica y política de Varela, Saco y José de la Luz, hasta donde lo permitieron las circunstancias, constituyó la raíz de ese ideal republicano y constitucionalista que llevó a nuestros mambises a luchar por una Carta Magna en la manigua insurrecta. Estos hombres pueden ser llamados perfectamente padres del constitucionalismo cubano, padres de la idea una Cuba

${ }^{12}$ Félix Varela, Cartas a Elpidio sobre la impiedad, la superstición y el fanatismo en sus relaciones con la sociedad, 1836, Madrid, Imprenta de D. León Amarita, pp. 4-5. libre e independiente. Para terminar, nada mejor que las palabras martianas sobre aquel alumbramiento de Guáimaro:

¡Con qué cuidado debe andar la pluma, y con qué ternura, cuando se escribe sobre aquellos hombres! Otros andamos por la senda abierta: ¡ellos fueron los que abrieron la senda! Por donde quiera que andemos los de ahora, hemos de andar con el sombrero quitado. Lengua, todos tenemos; pero espadas, pocos. De lo más bello del mundo es aquella juventud imperiosa, que no quería república patricia ni historia a medias; y aquel patriciado que sentó canas con la juventud. El desinterés es lo más bello de la vida; y el interés es su fealdad. El día de la generosidad absoluta en la historia de Cuba, ;fue el día 10 de abril!! ${ }^{13}$
${ }^{13}$ José Martí, La Revolución de 1868, 1968, La Habana, Instituto del Libro, selección y prólogo de Julio Le Riverend, p. 344. 


\section{UNA PARADOJA EN \\ LA MÁXIMA QUINEANA DE QUE NINGÚN ENUNCIADO ES INMUNE A LA REVISIÓN} Emilio Méndez Pinto*

RESUMEN: En este trabajo se muestra que, si se lleva a su conclusión lógica la máxima de Quine, "Ningún enunciado es inmune a la revisión" (es decir, a que la propia máxima quineana no es inmune a la revisión), desemboca una situación paradójica. Tal paradoja es, no obstante, inofensiva para la máxima de que "Ningún enunciado es inmune a la revisión" porque no la autorrefuta.

PALABRAS ClAVE: Quine, analiticidad, sinteticidad, enunciados autorrefutables, enunciados refutables.
THE PARADOX OF QUINE'S ADAGE

"NO STATEMENT IS IMMUNE TO REVISION"

ABSTRACT: In this article, we will show that if Quine's adage is fulfilled "No statement is immune to revision" (that is, that the adage is not immune to revision), it results in a paradoxical situation. Such paradox is nonetheless harmless to the adage "No statement is immune to revision" because it is undeniable.

KEYWORDS: Quine, analyticity, syntheticity, undeniable statements, deniable statements. 


\author{
UNA PARADOJA EN \\ LA MÁXIMA QUINEANA \\ DE QUE NINGÚN ENUNCIADO \\ ES INMUNE A LA REVISIÓN
}

La máxima es esta: "Ningún enunciado es inmune a la revisión". ${ }^{1}$ De esta máxima se sigue que para cada enunciado hay circunstancias en las que su rechazo sería racional. En Mente y cuerpo, Putnam ${ }^{2}$ sostiene que el enunciado "Ningún enunciado es inmune a la revisión" es, si se contempla lo que de él se sigue, falso: en ninguna circunstancia sería racional rechazar el enunciado "No

${ }^{1}$ W. V. O. Quine, "Two dogmas of empiricism", en W. V. O. Quine, From a logical point of view. Nine logico-philosophical essays, 1980, Harvard, Harvard University Press, p. 43.

${ }^{2}$ Hilary Putnam, "Mente y cuerpo", en Hilary Putnam, Razón, verdad e historia, 2006, Madrid, Tecnos, p. 90, en donde el argumento está expuesto tal como se encuentra aquí.

${ }^{3}$ Aquí consideraremos a la máxima de Quine como un enunciado más, es decir, como un miembro del conjunto de todos los enunciados. todos los enunciados son verdaderos", es decir, aceptar el enunciado "Todos los enunciados son verdaderos". No es difícil imaginar casos para los que el tipo de réplica de Putnam a la máxima de Quine funcione exactamente igual de bien. Por ejemplo, el caso más obvio: en ninguna circunstancia sería racional rechazar el enunciado "No todos los enunciados son falsos", es decir, aceptar el enunciado "Todos los enunciados son falsos".

Ahora bien, de ninguna manera ocurre que el tipo de réplica de Putnam sea igualmente válido para todos los casos de revisión de enunciados. Ocurre, más bien, que los enunciados "No todos los enunciados son verdaderos" y "No todos los enunciados son falsos" se prestan para 
mostrar que la máxima quineana de que ningún enunciado es inmune a la revisión (o, mejor dicho, lo que se sigue de esta máxima) es irremediablemente falsa para algunos casos. Pero este tipo de réplica, incluso conservando el término "todos" en los enunciados por revisar, no es válido, por ejemplo, en las ciencias naturales. En estas no hay enunciados analiticos, y por tanto, la máxima "Ningún enunciado [de las ciencias naturales] es inmune a la revisión" es perfectamente válida.

En esta breve nota me gustaría examinar otro aspecto de la máxima quineana. Este aspecto es el siguiente:

$\mathrm{Si}$

(1) Ningún enunciado es inmune a la revisión,

el enunciado (1) no es inmune a la revisión.

Una revisión radical ${ }^{4}$ del enunciado (1) nos haría aceptar que

${ }^{4}$ Una revisión radical es, por así decirlo, una revisión que da un giro de 180 grados al sentido original del enunciado en revisión. Por ejemplo, una revisión radical del enunciado "Todos los enunciados son verdaderos" produciría, una vez llevada a cabo, el enunciado "Todos los enunciados son falsos" o "Ningún enunciado es verdadero". Una revisión radical del enunciado "Todos los enunciados son falsos" produciría, una vez llevada a cabo, el enunciado "Todos los enunciados son verdaderos" o "Ningún enunciado es falso". Por otra parte, llamaremos revisión moderada a la revisión que, si bien transforma el sentido de un enunciado, no lo hace radicalmente. Por ejemplo, una revisión moderada
(2) Cualquier enunciado es inmune a la revisión.

Entonces el enunciado (2) es inmune a la revisión.

(Desde luego, si en esta teoría de enunciados vulnerables a la revisión se rechazan las revisiones radicales, el enunciado (2) nunca se produciría. En su lugar, resultarían enunciados derivados de revisiones moderadas del enunciado (1), del tipo "Algunos enunciados son inmunes a la revisión" o "Algunos enunciados no son inmunes a la revisión", lo que equivale a decir, respectivamente, que algunos enunciados no son revisables o que algunos enunciados son revisables. Es claro que entre cualquiera de estos dos enunciados y el enunciado (1) hay una diferencia significativa. Pero también es claro que en la teoría de enunciados vulnerables a la revisión no hay ninguna razón por la cual deban rechazarse revisiones radicales en aras de

del enunciado "Todos los enunciados son verdaderos" produciría, una vez llevada a cabo, el enunciado "No todos los enunciados son verdaderos" (o, equivalentemente, "Hay al menos un enunciado falso"), del mismo modo que una revisión moderada del enunciado "Todos los enunciados son falsos" produciría el enunciado "No todos los enunciados son falsos" (o, equivalentemente, "Hay al menos un enunciado verdadero"). Por último, también puede haber revisiones que, una vez llevadas a cabo, reafirmen al enunciado en revisión (es decir, que den, por así decirlo, un giro de 360 grados al sentido del enunciado en revisión, volviendo así al mismo lugar). Podríamos llamar "revisiones analíticas" o "revisiones circulares" a tal tipo de revisiones. 
privilegiar revisiones únicamente moderadas.)

Pero también habría que revisar, si hemos de ser consistentes (coherentes), el enunciado según el cual habría que revisar el enunciado (1). Entonces el enunciado

(3) El enunciado "Ningún enunciado es inmune a la revisión" no es inmune a la revisión

no es inmune a la revisión.

Pero entonces podría suceder que, bajo una revisión radical del enunciado (3) (ya vimos que no hay nada que nos impida hacer esto), aceptemos que

(4) No es el caso que el enunciado "Ningún enunciado es inmune a la revisión" no es inmune a la revisión.

Si aceptamos (4), entonces el enunciado (1) es inmune a la revisión.

En resumen: si llevamos a cabo una revisión radical del enunciado "Ningún enunciado es inmune a la revisión", nos encontramos con que el enunciado que resulta de tal revisión (es decir, (2)) es inmune a la revisión, mientras que si llevamos a cabo una revisión radical del enunciado según el cual habría de revisarse al enunciado "Ningún enunciado es inmune a la revisión" (es decir,
(3) y su propiedad de que no es inmune a la revisión), nos encontramos con que, a partir del enunciado que resulta de tal revisión (es decir, (4)), el enunciado "Ningún enunciado es inmune a la revisión" es inmune a la revisión.

En aras de la claridad, expondré lo anterior de la manera más explícita posible.

Si a la máxima quineana de que "ningún enunciado es inmune a la revisión" la consideramos como un enunciado más (es decir, como una afirmación que tiene el predicado de ser revisable), entonces una revisión radical de tal enunciado (es decir, una revisión que da un giro de 180 grados al sentido del enunciado "Ningún enunciado es inmune a la revisión") produce el enunciado "Cualquier enunciado es inmune a la revisión" o, equivalentemente, "Ningún enunciado es revisable". Inmediatamente es claro que, según lo que indica el propio enunciado "Ningún enunciado es revisable", este es inmune a la revisión.

Ahora bien, si revisamos radicalmente al enunciado que nos permite revisar el enunciado "Ningún enunciado es inmune a la revisión" (es decir, si revisamos radicalmente "El enunciado 'ningún enunciado es inmune a la revisión' no es inmune a la revisión"), nos encontramos con que "No es el caso que el enunciado 'ningún enunciado es inmune a la 
revisión' no es inmune a la revisión". Entonces, según esto último, el enunciado "Ningún enunciado es inmune a la revisión" es inmune a la revisión.

Este aspecto que resaltamos de la máxima quineana de que ningún enunciado es inmune a la revisión difiere del aspecto destacado por Putnam para la misma máxima en el hecho obvio de que a partir de nuestro examen surge una situación paradójica, mientras que del examen de Putnam resulta que la máxima quineana no es verdadera para cualquier caso. Sin embargo, la estrategia en ambos casos es esencialmente la misma: consiste en aplicar lo propuesto por la máxima "Ningún enunciado es inmune a la revisión" a la misma máxima "Ningún enunciado es inmune a la revisión". Para el aspecto que nosotros destacamos, tal estrategia fue explícita desde el principio, pero para el aspecto destacado por Putnam, tal estrategia también está presente (aunque sea de forma implícita). Si no fuese así, es decir, si la estrategia de Putnam no fuese la de aplicar lo sugerido por la máxima "Ningún enunciado es inmune a la revisión" a la propia máxima "Ningún enunciado es inmune a la revisión”, entonces no habría llegado a la conclusión de que tal máxima es falsa (al menos no en el modo en el que lo hizo). Esto, porque el rechazo a revisar el enunciado "No todos los enunciados son verdaderos" se sigue del rechazo a aceptar la máxima "Ningún enunciado es inmune a la revisión" como analíticamente verdadera, es decir, de la admisión de que la propia máxima "Ningún enunciado es inmune a la revisión" es revisable.

\section{¿Por qué la máxima de Quine no se autorrefuta?}

A modo de conclusión para esta breve nota, vale la pena examinar por qué, a pesar de todo lo dicho, la máxima "Ningún enunciado es inmune a la revisión" no se autorrefuta. Por el contrario, creo que, justamente por todo lo dicho, de algún modo sale reforzada, es decir, de algún modo sale validada. Para mostrar esto, consideremos de nuevo nuestra estrategia. Esta consistió en aplicar al enunciado "Ningún enunciado es inmune a la revisión" lo indicado por el propio enunciado "Ningún enunciado es inmune a la revisión". Nuestro enunciado en cuestión se habría autorrefutado si lo que expresa no fuese aplicable al propio enunciado, ${ }^{5}$ es decir, si el enunciado "Ningún enunciado es inmune a la revisión" no fuese revisable por el mismo canon de que

${ }^{5}$ Obviamente, si las afirmaciones o los supuestos que contempla un enunciado $x$ no se cumplen para un enunciado $y$, pero sí para el propio enunciado $x$, entonces el enunciado $x$ se refuta, pero no se autorrefuta. 
ningún enunciado es inmune a la revisión. Como inmediatamente se ve, esto es un absurdo (sencillamente porque "Ningún enunciado es inmune a la revisión" es semánticamente equivalente a "cualquier enunciado es revisable").

Precisamente por este absurdo, de cierto modo se valida la máxima quineana: esta puede refutarse (como cuando uno considera los casos de que "No todos los enunciados son verdaderos" o de que "No todos los enunciados son falsos", que no sería racional rechazar en ninguna circunstancia), pero no se autorrefuta. (He aquí su carácter no analítico, ique es justamente la caracterización quineana de los enunciados!) Esta propiedad, la de no autorrefutarse, no la tiene, por ejemplo, una de las máximas más influyentes en la teoría del conocimiento del siglo XX: el criterio de significación del positivismo lógico. Este criterio es que "el significado de una oración es su método de verificación”, y la exposición de por qué se autorrefuta se debe, en un sentido importante, a Putnam:

En los últimos cincuenta años, la manifestación más clara de la tendencia a pensar que los métodos de "justificación racional" son otorgados por algo así como una lista o canon (si bien esos filósofos de la ciencia admiten no haber logrado aún una forma- lización plena) fue el movimiento conocido como Positivismo Lógico. Los positivistas no solo confiaban en que los "lógicos de la ciencia" (este era su término para denominar a los filósofos) lograrían dejar constancia escrita de una descripción (pretendidamente exhaustiva) del método científico, sino que, según ellos, el "método científico" agotaba la propia racionalidad, y la contrastabilidad mediante ese método agotaba la significatividad ("el significado de una oración es su método de verificación"); la lista o canon determinaría lo que tiene significación cognitiva. Los enunciados contrastables mediante métodos pertenecientes a la lista (los métodos de la matemática, la lógica y las ciencias empíricas) contarían como significativos; los positivistas mantenían que todos los demás eran sólo "pseudo-enunciados", o sinsentidos disfrazados.

Una réplica obvia consistía en afirmar que el criterio de significación del positivismo lógico se autorrefuta: el mismo criterio no es ni (a) "analítico" (un término que los positivistas utilizaban para dar cuenta de la lógica y de la matemática), ni (b) empíricamente contrastable. ${ }^{6}$

${ }^{6}$ Hilary Putnam, "Dos concepciones de la racionalidad", en Hilary Putnam, Razón, verdad e historia, p. 111. 


\section{Un ejemplo más de una máxima que se autorrefuta}

Considérese la máxima de que "El significado de un enunciado es su uso". $7 \mathrm{Si}$ el significado de un enunciado es su uso, entonces el significado del enunciado "El significado de un enunciado es su uso" es su uso. "El significado de un enunciado es su uso" quiere decir que el modo en el que se usa un enunciado condiciona su significado (claramente, no puede determinar su significado porque este está sujeto al uso, que no es uno sino múltiple). Ahora bien, si un uso específico y lingüísticamente legítimo o válido del enunciado "El significado de un enunciado es su uso" llegase a condicionar su significado ( $\sin$ llegar a determinarlo), ¿cuáles serían otros usos igualmente específicos y lingüísticamente legítimos o válidos del enunciado "El significado de un enun- ciado es su uso" que igualmente condicionarían su significado (sin llegar a determinarlo)?

Prima facie, parece que no hay una clase de casos de utilización (por más pequeña que sea) del enunciado "El significado de un enunciado es su uso" que, en distintos contextos, énfasis, intenciones, etc., condicione el significado del enunciado "El significado de un enunciado es su uso"; en otra palabras, parece que el uso del enunciado "El significado de un enunciado es su uso" es irrelevante al momento de especificar (indicar, mostrar, etc.) su significado: este es literalmente "El significado de un enunciado es su uso" indistintamente del uso del enunciado "El significado de un enunciado es su uso". Si lo anterior es correcto, entonces la máxima de que "El significado de un enunciado es su uso" se autorrefuta.

\footnotetext{
${ }^{7}$ Este tema lo considero detalladamente en Emilio Méndez Pinto, ¿Se autorrefuta el supuesto de que el significado de un enunciado es su uso?, 2016, México, La Reina de las Ciencias, Biblioteca Digital del ILCE, UNESCO. Este trabajo es una extrapolación, para el caso de los enunciados, del principio de Wittgenstein según el cual el significado de una palabra es su uso en el lenguaje. Véase Ludwig Wittgenstein, Investigaciones filosóficas, 2003, México, Instituto de Investigaciones Filosóficas, UNAM, p. 61. No obstante, de este principio de Wittgenstein no debe seguirse que Wittgenstein propuso una teoría según la cual "el significado es el uso". Para este último punto, véase Hilary Putnam, El pragmatismo. Un debate abierto, 2006, Barcelona, Gedisa, p. 23.
} 
CITAM Derechos Reservados.

La reproducción total o parcial de este artículo se podrá hacer si el ITAM otorga la autorización previamente por escrito. 


\section{RESEÑAS}

Zygmunt Bauman y Carlo Bordoni, Estado de crisis, 2016, Barcelona, Paidós, trad. de Albino Santos Mosquera, 205 pp.

RECEPCIÓN: 5 de febrero de 2017.

APROBACIÓN: 13 de febrero de 2017.

E te reciente libro de Bauman reproduce un largo diálogo con Carlo Bordoni, estudioso y docente de sociología en las universidades de Pisa y Florencia, en el Instituto Oriental de Nápoles y en la Academia de Bellas Artes de Carrara. Carlo Bordoni es especialista en la sociología de la cultura.

El diálogo comprende tres partes o capítulos: el primero está dedicado a la crisis del Estado, el segundo a la modernidad en crisis y el tercero a la democracia en crisis.

Se parte del significado etimológico de la palabra crisis, que significa, según Tucídides, "sentencia", "punto de inflexión", "selección" o "decisión", y, según Platón, "disputa" o "querella". El término, aplicado a la economía, significa un cúmulo de circunstancias desfavorables, propio de una fase de recesión caracterizada por un freno de las inversiones, una reducción de la producción y un incremento del desempleo.

Señala Bordoni que lo propio de la crisis actual es el ser financiera, en tanto que la de 1929 fue más bien industrial. Se caracteriza igualmente por su ya larga duración, lo que crea un clima de inseguridad y malestar generalizado.

Bauman subraya un aspecto que ha sido destacado en su pensamiento, a saber, que esta crisis se ha acentuado con la mayor separación que existe en el Estado entre el poder (es decir, la capacidad para conseguir que se hagan las cosas) y la política (es decir, la capacidad para decidir qué cosas debieran hacerse). El Estado, que tras el derrumbe del colonialismo había adoptado un carácter asistencialista (como Estado de bienestar), fue manifestándose, sobre todo después de 1970, como absolutamente incapaz de cumplir sus promesas. "El Estado fue degradándose desde la categoría de motor más poderoso de bienestar universal a la de obstáculo más detestable, pérfido y molesto para 
el progreso económico" (p. 21). Entonces, la confianza pública se puso en el mercado, en "la mano invisible del mercado" y se abogó por la "desregulación" o "privatización" de las iniciativas que el Estado no había logrado conseguir.

Con ello, se pasó de un periodo de "orgía consumista" y crecimiento prácticamente imparable, a otra fase en la que las viejas esperanzas desaparecieron y se produjo "la degradación social de una clase media otrora segura, bulliciosa y con aspiraciones de ascenso social, a la categoría de un perplejo, indefenso y amedrentado precariado" (p. 22). Aumenta sin cesar el número de seres humanos en situación de precariedad, que son social y económicamente inútiles, desechables o "descartables", que se acumulan en ese "gran cubo de basura" que son las ciudades y que son producidos por poderes globales sobre los cuales el Estado carece de control.

Al separarse el poder de la política aparece una fuerte aversión a los partidos políticos, lo que da pie al populismo y al nacionalismo, que suelen anunciar regímenes tiránicos y dictatoriales. El problema estriba en qué pueda hacer el Estado que ha perdido el poder y se encuentra "administrado por los mercados, por los grupos financieros, por fuerzas supranacionales que se sustraen a todo control democrático" (p. 28). Los partidos políticos están muy lejos de poder cumplir las promesas hechas si acceden al gobierno. De ahí la creciente desconfianza y escepticismo de los ciudadanos. Solo cabe una "indignación" que desemboca en total impotencia.

En este panorama, Bauman deposita su confianza en una Unión Europea que "es un laboratorio en el que se diseñan, se debaten y se prueban a través de la práctica diaria formas de afrontar esos desafíos y de abordar esos problemas [globales]" (p. 39).

En relación con este último punto, Bauman hace una afirmación que ha quedado brutalmente desmentida por los hechos: afirma que los Estados han quedado limitados a vigilar la ley y el orden capitalista, lo que significa - dice - que ninguno de los miembros de la Unión Europea, por ejemplo, puede abandonar esa formación europea por los intereses que están en juego: ni Grecia, ni Chipre, ni siquiera la Gran Bretaña, en la cual Camerón ha prometido, "de cara a la galería", que se podría llegar a tal extremo. Sin embargo, "los mismos intereses empresariales [...] no admitirían que las cosas llegasen tan lejos" (p. 55). El plebiscito realizado precisamente en la Gran Bretaña el pasado 23 de junio ha demostrado que esto no era cierto.

En el segundo capítulo, dedicado a la modernidad en crisis, se examinan las promesas mantenidas por la modernidad, que fueron fundamentalmente las de una seguridad colectiva aunada a la libertad, todo en el marco 
referencial de un progreso permanente. Naturalmente, esto era a-histórico, cuando no anti-histórico - tendencia frenada por el romanticismo-y muy pronto dejó ver el conflicto que existía entre seguridad y libertad. Durante años de consumismo irrefrenable, de productividad destinada a satisfacer y alentar ese consumismo, se pudo mantener la creencia. "Hubo que esperar dos siglos más para que Sigmund Freud proclamara que 'la civilización' (sinónimo de orden creado y gestionado por el hombre) es un equilibrio entre seguridad y libertad; no una cooperación entre ambos conceptos, sino un juego de suma cero en el que lo que se gana en uno de ellos se pierde en el otro. Ese es un conflicto del que difícilmente veremos nunca el final" (p. 83).

Los autores polemizan sobre si la crisis indudable de la modernidad (e incluso la posmodernidad) ha terminado ya — tal es la posición de Bordonio si todavía se aguardan los resultados de sus promesas. Esta última es la posición de Bauman, quien señala que "la Iglesia del Crecimiento Económico es una de las pocas congregaciones — quizá la única— que no parece perder fieles y que tiene probabilidades reales de alcanzar un verdadero estatuto ecuménico. La ideología de la 'la felicidad a través del consumo' es la única que tiene alguna probabilidad de anular, imponerse [...] y terminar con [...] todas las demás ideologías” (pp. 96-97). Y “el más grandilocuente de los relatos modernos - el del progreso del control humano sobre la Tierra, guiado por la Santísima Trinidad de la Economía, la Ciencia y la Tecnología-, parece encontrarse en mejor estado de salud que nunca" (p. 97). Pero esta modernidad se presenta en un mundo en que todo se ha vuelto inestable, precario, provisional e incierto; todo se ha vuelto "liquido". Ello ha conducido a un individualismo feroz, a la desaparición de la solidaridad social y "el poder y la política viven y se mueven separados el uno de la otra y su divorcio definitivo nos aguarda a la vuelta de la esquina" (p. 119).

La notoria impotencia e ineptitud de la dimensión política genera un número creciente de personas en permanente situación de protesta y movimiento. Se siente la necesidad de auténticos líderes políticos y espirituales, pero es sumamente difícil en el mundo cambiante y líquido en el que vivimos.

Lo anterior conduce naturalmente a la tercera parte, dedicada al estado de crisis de la democracia. Buena síntesis de esta sección son las palabras de Richard Rorty que aparecen como epígrafe: "tenemos ahora una clase superior que toma todas las grandes decisiones económicas y lo hace con total independencia de los parlamentos y, con mayor motivo, de la voluntad de los votantes de cualquier país dado" (p. 141). 
Idea fundamental que atraviesa esta sección es que hay actores globales que se mueven en el mundo contemporáneo y que generan una serie de problemas a los cuales se enfrentan esos diferentes entes particulares que son los Estados. En el capitalismo financiero en el que vivimos, ya no hay dueños, sino "simplemente ejecutivos de empresa que mueven dinero virtual a una velocidad extrema" (p. 143). Pero — señala Bauman — la crisis más grave de todas es la que aqueja a las instituciones democráticas por atacar a los únicos instrumentos de acción colectiva existentes.

Frente a los graves problemas creados por los actores globales, tales como la migración, la contaminación de las reservas de agua, los imparables crecientes costos de los servicios sanitarios, los agentes globales se lavan las manos y renuncian a toda responsabilidad.

En cuanto a la democracia, alejada ya de sus orígenes históricos griegos y de su significado de gobierno del pueblo y para el pueblo, hoy se reduce a la cuestión de la representatividad, tal como ya lo señalaba Rousseau. El problema fundamental está en las relaciones entre el poder central y la voluntad popular. Y esto, como ha demostrado la historia, puede adquirir formas sumamente diversas, desde la dictadura de un partido a la emergencia de un líder carismático y populista.

Por esta razón, Bordoni habla de una posdemocracia caracterizada por una serie de notas, como la anulación de reglas que gobiernen las relaciones económicas, la disminución de la participación ciudadana, el retorno del liberalismo económico, la decadencia del Estado de bienestar, la política como espectáculo, etc. Finalmente, "lo cierto es que la actual situación de 'desfallecimiento' democrático se debe principalmente a la crisis del Estado, a la incapacidad de este para actuar como interlocutor fuerte y decisivo de la mediación social, como regulador de la economía, como garante de la seguridad" (p. 172). La posdemocracia presenta una sociedad de masas que descansa sobre el reconocimiento oficial de ciertas libertades formales a cambio del dominio del consumismo en una situación de conformidad. Resultado práctico es una sociedad globalizada dirigida por la economía y los mercados y que se encuentra compuesta por una mayoría carente de derechos y servicios, sumamente empobrecida y dirigida por una minoría privilegiada.

En las últimas páginas, Baumann señala la dificultad para visualizar lo que será 'un nuevo orden global', pero que seguramente estará dominado por un consumismo sin freno en el que solo cuenta la satisfacción inmediata e individual. Los objetos de consumo procuran satisfacer tal apetito de novedad 
e incitar nuevos deseos en una cadena interminable. Las relaciones interpersonales quedan reducidas a esa relación que se establece con los objetos de consumo, relación dominada por el deseo, el consumo, la satisfacción pasajera y el descarte. Se habrá llegado a lo que se conoce con el nombre de 'relaciones puras' que son relaciones "no limitadas por el compromiso de una duración y un alcance indefinidos" (p. 183). Tales relaciones se basan exclusivamente en la satisfacción que proporcionan, y pierden su razón de persistir cuando la satisfacción mengua o desaparece.

Finalmente, se trata — dice Bauman - de un problema moral, pues se reduce al ser humano al nivel de una mercancía, valiosa por satisfacer un deseo, que proporciona una satisfacción momentánea, pues se está siempre en espera de algo nuevo y lo viejo será descartado sin ningún remordimiento. "Sofocados ya los remordimientos morales antes de que se vuelvan verdaderamente enojosos y preocupantes, la red de vínculos humanos tejida con el hilo moral se va haciendo cada vez más precaria y frágil, hasta el punto de descoserse por las costuras" (p. 187). Con ello, "no solo están amenazadas así la política y la supervivencia de la comunidad. Nuestra proximidad 'persona-a-persona' y la satisfacción, la sensación de realización personal, que obtenemos de ella también corren peligro al enfrentarse a la presión conjunta de una visión consumista y del ideal de "relaciones puras"' (p. 187).

En su obra anterior, Ceguera moral, ya Bauman había elaborado las consecuencias de la modernidad idealista, que reducen el ser al ser-conocido; la realidad al ser-deseado; el objeto al ser-consumido. Es la primacía de un individualismo narcisista que desconoce la realidad objetiva y, en el mundo de las relaciones personales, la negación del Otro. Lo que está en juego es precisamente la habilidad del ser humano para conocer y contemplar la realidad, la capacidad para descubrir al Otro y sus inmensas perfecciones. Es lo que tanto temía el último Heidegger, ese mundo reducido al ser-útil y ser-usado. Es curioso que lo esencial es aquella pregunta fundamental y aparentemente inocua que se le hacía al personaje principal de El Principito: ¿cómo se hace un amigo? 
Slavoj Zizek, La nueva lucha de clases. Los refugiados y el terror, 2016, Madrid, Anagrama, Colección Argumentos, trad. de Damià Alou, 135 pp.

RECEPCIÓN: 16 de enero de 2017.

APROBACIÓN: 7 de marzo de 2017.

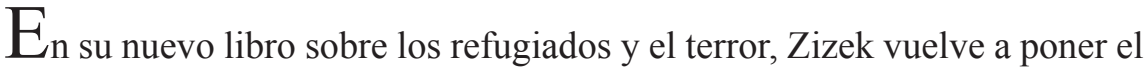
dedo en la llaga de las contradicciones y tabúes que giran en torno al tema. $\mathrm{Su}$ ataque a los liberales de izquierda pretende que volvamos a hablar de la lucha de clases que ahora se perfila en el mundo. La causa de los conflictos que han desatado la ola de inmigrantes, las políticas fascistas contrarias a la inmigración y los populismos nacionalistas, se basan en el desconocimiento de que esa lucha de clases refleja los antagonismos actuales, que son propios de lo que podemos llamar el éxito del capitalismo global dentro de una dinámica de inclusión y exclusión.

De nuevo, Zizek usa las categorías de Lacan para analizar la dimensión del goce y la perversa transgresión de la culpa del llamado superyó, que es la instancia de la ley, para explicar que detrás del sentimiento humanitario de los que rechazan el fundamentalismo islámico hay una hipocresía notable. A más culpa más transgresión, y, desde luego, el placer perverso del goce separa a unas sociedades que envidian el goce de otras determinando el rechazo del multiculturalismo. En ese sentido, una de las tesis que se esgrimen es que ese humanismo universalista que siente compasión por los refugiados encubre formas de racismo moderadas en las que nunca se es suficientemente tolerante con el extranjero. Al mismo tiempo, olvida que el fundamentalismo también es cristiano o judío. Y que las causas del conflicto están relacionadas con el capitalismo global que ha dejado fuera del sistema a tres cuartas partes de la humanidad. Peor todavía, es la dinámica del capital la que ha causado los conflictos en África y el Medio Oriente, que ahora se significan como centros de expulsión de migrantes hacia Europa. Por eso, se debe comenzar con la 
denuncia de los tabúes clásicos. Luego, reconocer la dimensión perversa del envés de las religiones y del liberalismo laico (que es radical o moderadamente racista). Analizar la economía de los refugiados y el negocio que supone su existencia, pues incluso es toda una industria que nadie sabe quién sostiene (reclutarlos, darles balsas, recogerlos, llevarlos, distribuirlos; eso cuesta mucho dinero, y luego esos refugiados trabajan por centavos en maquilas chinas cerca de Florencia, por ejemplo). Es la lucha de clases el principio estructurador en sentido althusseriano el que determina los antagonismos entre blancos conservadores y blancos ricos liberales, o entre países desarrollados y países expulsores de migrantes, que, como México, exportan la mercancía de sus braceros que son libres para trabajar donde se les necesita sin libertad de movimiento (y ahora son el enemigo de fuera que separa a los estadounidenses de lo Otro; ergo, deportables a cambio de la unidad de América). Identifica la amenaza como exterior cuando su origen es interno, pues los antagonismos existen en los propios países entre clases medias en crisis, pobres desempleados y élites acomodadas que ven en el extranjero lo que adentro ya ocurre con la identificación simbólica de las minorías y parias que son tratados igual que esos extranjeros. Es preciso, además, preguntarse por lo que significa hoy Europa y por sus posibilidades.

En cuanto a los tabúes de la izquierda liberal, Zizek identifica los siguientes: el primer tabú es pensar que el enemigo es alguien cuya historia no se ha escuchado. Es el caso de Frankenstein. Mary Shelley presenta un monstruo que espanta, pero cuando se escucha su historia, lo único que desea es que se le escuche, que cuente, y al hablar deja saber que solamente quiere que lo amen. De la misma forma, habría que escuchar a Hitler y quizá ver los motivos que desde su historia lo condujeron a matar judíos. Pero diga lo que diga Hitler, sus actos son imperdonables, moralmente inaceptables, así explicase que solamente reaccionaba a sus traumas de soldado del frente en la Primera Guerra Mundial o que pensaba seriamente que la pobreza de Alemania era causada por judíos codiciosos (siguiendo la ideología que describe a los judíos con significantes clásicos: raro-ritualista-usurero-sionista). El segundo tabú de la izquierda es considerar el imperialismo europeo como causante de los males del Medio Oriente y África. Pensar que los valores europeos son eurocéntricos olvida que es el capitalismo global, que además es europeo, chino, indonesio, americano, el que segrega a tres cuartas partes de la humanidad, donde hay países que quieren mimetizarse con las formas capitalistas. Hoy, el capitalismo se adapta a cualquier sistema político y a todas las religiones. 
Otro tabú es pensar que nuestro modo de vida europeo occidental es racista. Los izquierdistas liberales dicen que Europa, en aras a preservar su modo de vida, ha girado a una derecha racista que ahora vemos en Suecia, Austria y pronto en Francia. Pero no ven que la protección de nuestro modo de vida es la que ha hecho recrudecer las políticas antiinmigración. Es tiempo de que pensemos que la apertura a la inmigración enriquece el modo de vida, y que su protección es justamente la apertura en la que el inmigrado tiene que identificarse con las formas occidentales a las que llega. El sistema antiinmigración es una amenaza mayor que todos los inmigrantes juntos. Dicen los izquierdistas que cualquier crítica al islam es islamofobia, y ese es otro tabú. Se olvida que muchos países islámicos son capitalistas, no reciben inmigrantes, colaboran con Occidente y son modernos, como Catar, Emiratos Árabes Unidos, Arabia Saudita, Kuwait. No es cierto que el islam se oponga al capitalismo. Otro tabú es pensar que la religión politizada es racista, considerando a los islamistas como fanáticos premodernos. El Corán permite que en la vida privada cada quien crea lo que desee, que es diferente a que lo predique públicamente. En ese sentido, los países islámicos defienden una religión que permite la libertad interior de pensamiento. Por costumbre y cultura, los islamistas se comportan de acuerdo con las reglas sociales de tradiciones que nos parecen premodernas. También entre los judíos se dan conductas de este tenor. Zizek narra que un fin de semana de junio de 2015, cuando los homosexuales de Nueva York celebraban en público su gran victoria por la legalización del matrimonio gay, los opositores habían organizado manifestaciones contestatarias. El Comité Judío de Acción Política contrató mexicanos disfrazados de judíos para que protestaran en defensa del judaísmo como expresión que rechaza la homosexualidad. Los rabinos dijeron que lo habían hecho para evitar que sus jóvenes vieran a los homosexuales en las calles, pues podría dañar su moral, y seguramente esos muchachos estaban en la calle contoneándose al lado de los gays. Muchos judíos que no creen en Dios creen, empero, que la tierra prometida por Dios es de ellos, que son inteligentes y tienen razón. El fundamentalismo no es necesariamente islámico. Hoy, los defensores de los musulmanes en Europa son los ateos liberales, que promueven la tolerancia. Son esos liberales los que permitieron que las caricaturas de Mahoma se publicaran en los medios impresos para defender la libertad de expresión, y contra ellos fueron los fundamentalistas, que no fueron todos los musulmanes establecidos en Francia.

No podemos olvidar que el fundamentalismo también es cristiano, católico. Los casos de pederastia en la Iglesia católica se encubren para proteger a 
la misma Iglesia. La censura contra los pederastas no implica que los mismos miembros de la Iglesia denuncien a los sacerdotes que saben que son pederastas, sino que más bien se callan. De la misma forma, cuando los musulmanes no se integran cometen delitos contra las mujeres. (En el caso Róterdam, entre 1997 y 2013, 1400 niñas fueron explotadas y violadas por bandas pakistaníes. La izquierda dijo que esos "asiáticos" seguían sus "costumbres" y recalcaban la superioridad que tienen los hombres sobre las mujeres en esa cultura, en lugar de juzgarlos simplemente como criminales.) Los sucesos de Róterdam y la pedofilia son actividades colectivas y ritualizadas, y se refieren a la violencia sistemática contra las mujeres. Las muertas de Juárez, en México, colectivizan acciones machistas contra mujeres que se quieren emancipar. Así, la brutalidad no es meramente islámica.

Hay que recordar que la violencia tiene dos sentidos: la que se dirige hacia una meta y la violencia por sí misma. Es el caso de la llamada "violencia divina", en la que, siguiendo a Benjamin, se muestra un colectivo violento que solamente expresa enojo sin emprender una lucha organizada con fines específicos. Ese fue el caso de los negros de Ferguson que salieron a protestar contra el racismo de policías blancos que habían asesinado a un adolescente negro, o las protestas de los musulmanes en París, que incendiaron coches, en 2005, mientras Sarkozy los calificaba de escoria. Esos musulmanes atacaron propiedades de su propia comunidad porque su violencia era ira sin orden, una expresión con un afán de reconocimiento sin fin utópico ulterior. La máxima kantiana de que nunca debiera haber violencia no es generalizable a casos en los que estalla sin ningún fin una ira que ningún sociólogo podría explicar. Nada se puede hacer cuando las condiciones previas crean o configuran una expresión violenta que no hace falta interpretar. Que los palestinos maten judíos con cuchillos es una situación de violencia divina que no tiene nada de noble ni sublime, ni tampoco emancipa a nadie ni persigue un fin utópico; es solo ira que se detona por la injusticia vivida. Violencia pura. Pero hay razones de tanto encono en todos lados. Zizek las encuentra en la economía política de los refugiados. Con dos ejemplos se entiende su argumento. El desorden mundial actual es el Nuevo Orden que tanto Estados Unidos como Europa y Rusia han propiciado. La intervención europea en Libia sumió ese país en el caos, pero Gadafi controlaba ese muro que impedía el paso de inmigrantes a Europa. La intervención de Estados Unidos en Irak creó las condiciones para el surgimiento del Estado Islámico. En la República Centroafricana se enfrentan el sur cristiano y el norte musulmán, pero detrás de esa guerra está 
la causa: fue provocada por las potencias de Occidente al encontrar petróleo en el norte. Francia apoya a los musulmanes y China a los cristianos, pero de eso no se habla. Bill Clinton confesó, en el Día Mundial de la Alimentación declarado por la Organización de las Naciones Unidas, según informó Associated Press el 23 de octubre de 2008: "La fastidiamos, todos la fastidiamos, incluido yo cuando era presidente", pues el proyecto era sacar a los campesinos de sus tierras, apoyar a las grandes corporaciones, tratar los alimentos como mercancías, abandonar los subsidios para dejar todo al juego del mercado, y así las mejores tierras fueron para cultivos de exportación. El resultado fue que millones de campesinos se quedaron sin tierra y emigraron, como los mexicanos que se van a los Estados Unidos. Y las hambrunas en Haití y Etiopía. Casi todos los refugiados provienen de Estados fracasados en los que se ve la mano de Europa y Estados Unidos. Las empresas extranjeras de alta tecnología saquean materias primas, mecanizan procesos, empobrecen a obreros y campesinos, y eso produce enfrentamientos entre etnias de África y migrantes en países pobres.

Por otro lado, las guerras culturales separan unas culturas de otras. El modo como goza una cultura no es el de otra, y entre las culturas hay choques. El mito del multiculturalismo, el humanismo, no hace sino encubrir la brecha que separa a unos de otros. Los refugiados en Calais quieren ir al Reino Unido, los que están en Italia quieren ir a Suecia o Noruega, porque se inventan su 144 goce en espacios que no existen. Mientras, los países invadidos reaccionan exigiendo que los intrusos regresen a sus países de origen, de los que huyen por el hambre y la miseria y la violencia que los mismos occidentales han causado. Ahora, los mexicanos deben volver a su país. Pero los indígenas, ¿ ¿adónde irán? Las políticas antiinmigración se afianzan en el populismo nacionalista conservador que líderes de guiñol ofrecen a los blancos pobres, subempleados o desempleados, con el objeto de culpar al Otro del antagonismo que hay adentro de los propios países expulsores de gente. Unos acumulan las ganancias en Wall Street, y a los millones de granjeros blancos se les dice que hay que expulsar a mexicanos y chinos. Pero no se dice que la lucha de clases interna es la causa de su pobreza. A Bernie Sanders se le criticaba que fuera a hablar con esos conservadores granjeros blancos republicanos para tratar de unirlos a todos, porque la izquierda crítica justifica el antagonismo que en la teoría quiere resolver. El origen del problema no es que la democracia esté amenazada por los extranjeros, que efectivamente no se adaptan del todo a los valores democráticos. El origen está en la propia identidad europea. Hay una crisis 
capitalista global, financiera, social. Los mismos europeos segregaban a Grecia y España. La Unión Europea justificaba su unidad al luchar contra la inmigración, sin ver hacia adentro las escisiones de clases, la separación entre las economías, los populismos de derecha que quieren romper esa misma unión por razones económicas. El racismo de ricos contra pobres, el rechazo al prójimo como ese Otro pobre con quien nada tiene que ver el rico, sostiene y preserva una lucha de clases en la que millones viven mal gracias a élites que tienen todo. El Otro es alguien cuyo modo de vida nos molesta, por eso el apotegma "ama a tu prójimo como a ti mismo" realmente significa "aléjalo lo suficiente para tolerarlo". Y en el caso de los inmigrantes, aléjalos más. La lucha de clases interna explica el rechazo al inmigrante, al refugiado. Y a la vez, el terror es una expresión ideológica de grupos armados, con dinero, que movilizan parias que hacen estallar bombas y adeptos que se sacrifican. De los guetos pobres van a los centros del glamour a recordar que hay lucha de clases. El Estado Islámico no es una organización sin recursos. Sus crímenes se aprovechan de tres elementos: las intervenciones occidentales que lo crearon, la lucha de clases del capitalismo global y los sistemas de exclusión de los países que ven en el Otro al enemigo. Así, la guerra no tiene fin.

Libro polémico, lacaniano, dialéctico, poco esperanzador, del filósofo esloveno de aguda mirada.

JOSÉ MANUEL OROZCO GARIBAY

Departamento Académico de Estudios Generales, ITAM 
José Manuel Orozco Garibay, Nietzsche y la tragedia, 2016, México, Editores de Textos Mexicanos, $218 \mathrm{pp}$.

La esperanza es el peor de los males, pues prolonga el tormento del hombre

F. NIETZSCHE

RECEPCIÓN: 15 de noviembre de 2016.

APROBACIÓN: 25 de febrero de 2017.

¿T iene sentido escribir un libro sobre Nietzsche y la tragedia el día de hoy? Sin duda, Nietzsche representa un gran reto para los escritores que lo abordan. En primer lugar, las dificultades para entenderlo correctamente, ya que del mismo tema (el superhombre, la voluntad, el eterno retorno o la belleza de la tragedia) se pueden dar diversas interpretaciones y, paradójicamente, todas ellas ser válidas.

Por otra parte, no se puede escribir objetivamente acerca de su obra, ya que nuestras emociones de inmediato se conectan con él, de modo que el análi-

146 sis de sus libros se vuelve vivencial, al mismo tiempo que racional. El mismo Nietzsche afirma que toda filosofía no es más que una autobiografía. En la introducción a su libro, José Manuel Orozco lo reconoce también: "el autor de este libro ha vivido cuanto ha puesto en estas páginas" (p. VI).

Se necesita no solo un conocimiento profundo de Nietzsche, sino también una gran valentía para interpretar su obra. Orozco corre un gran riesgo al analizar, relacionar y evaluar la tragedia, que es uno de los temas más importantes del pensamiento del filósofo alemán.

En su recorrido, Orozco conduce al lector a una mejor comprensión del filósofo: desde la concepción artística de la vida, pasando por el conocimiento, el espíritu libre y el eterno retorno hasta concluir en un tema controversial y de intensas paradojas como el amor trágico. "Se dice que la mujer enamorada engatusa al hombre que escoge permitiendo que sienta que tiene un control que le pertenece solamente a ella. Quizá solamente el hombre es fuerte cuando sabe decir 'no'. Cuando se aleja a tiempo" (p. 198).

Han pasado 116 años desde la muerte de Nietzsche, y su pensamiento sigue siendo tema de reflexión y estudio en la filosofía occidental. Lo novedoso 
de sus ideas, la creatividad para desarrollarlas, la fuerza y originalidad de sus conceptos tienen mucho que decirnos en la vida de hoy.

Nietzsche ha sido visto como filósofo moral, crítico de todos los temas de la cultura, fundador metafísico de un nuevo sistema de ideas. Más que un filósofo de su tiempo (siglo XIX), parecería que a Nietzsche se le podría ubicar perfectamente como un pensador de la actualidad. El eterno retorno, la voluntad de poder, el sufrimiento humano, todo esto que forma la tragedia humana y que vemos una y otra vez pasar en la historia de la humanidad, nos sigue causando admiración y emoción, puesto que lo vemos en otros y también lo vivimos todos los días.

Llevó una existencia plagada de malestares físicos. Haciendo recuento de sus enfermedades, sabemos que padeció migrañas, difteria, sífilis en todas sus etapas, dolencias en los ojos y demencia. También sufrió traumas y complejos debidos a una fuerte y excesiva educación religiosa. Además, a sus malestares se suma uno que marcó su vida: su mala relación con las mujeres, tanto con su madre y su hermana como sus amores frustrados, como el de Lou Salomé.

Las relaciones amistosas pero también de competencia dolorosa que sostuvo con músicos y poetas lo hicieron un hombre sufriente que encontraba en muchas ocasiones refugio en la naturaleza. Tenemos noticias de sus largas caminatas en Sils Maria, de la búsqueda de alivio para sus fuertes dolencias físicas en distintos lugares de Europa y del famoso encuentro con el caballo, en Turín, con el que inicia su descenso a la locura.

Sin duda, pues, sufrió grandes dificultades; sin embargo, muchos otros, filósofos o no, las han enfrentado también. ¿Cuál es la diferencia con Nietzsche? Lo nuevo en él es que le dio un sentido original al sufrimiento, diferente a la respuesta que da el cristianismo, al que conoció muy de cerca. Afirmó la vida mediante la tragedia, porque solo sufriendo se puede gozar. Un hombre superior se forja en la lucha y la dureza, el sufrimiento es una afirmación de vida a través de la destrucción de la vida. Es la única opción de vivir plenamente, de crearse en la existencia, de continuar en el camino teniendo como finalidad la contemplación de la belleza que emerge del propio sufrimiento.

Para Nietzsche, el hombre es una obra de arte, es una tragedia, que define como la caída de lo sublime. Para crearla, tiene que realizar primero la figura de un héroe fuerte, poderoso, cercano a los dioses y desde la posición más alta, en lo sublime, desde ahí, caer hasta lo más profundo, lo más bajo.

¿De qué manera el hombre es una tragedia? En la espera, en las ilusiones sobre sí mismo y los demás; al formarse un sueño de la vida y abrigar expectativas muy altas de sí mismo. Así vendrá la caída, el saber que volvemos 
una y otra vez a deshacernos en el principio y el origen, en la voluntad que es la fuerza original.

¿Por qué esperar tanto de la vida y de nosotros mismos si sabemos que es imposible? Precisamente para elaborar nuestro personal sufrimiento en la tragedia y reconocer que por más que se intente, la caída es inevitable, lo mismo que la muerte y el constante regresar a deshacer la forma que hemos inventado de nosotros mismos.

Nietzsche explica la tragedia diciendo que en el hombre residen dos espíritus de los dioses griegos: Apolo y Dionisio. Dionisio es la fuerza de la vida, la embriaguez, el inspirador de la locura, el caos y la oscuridad. Por su parte, Apolo es dios de la claridad, la luz, la razón y la armonía. Apolo y Dionisio entablan una relación de lucha constante de lo titánico y lo bárbaro. Apolo quiere ocultar a Dionisio con el velo de Maya, pero Dionisio lo desgarra para expresarse. Están en lucha pero también en reconciliación. Apolo, principio de individuación, crea la separación entre los hombres; Dionisio recuerda que somos uno y lo mismo, principio de especificación. Así el hombre, en esta lucha de opuestos, crea todos los días su propia tragedia, querer y no poder, esperar ser un yo y darnos cuenta de que estamos inmersos en la vida y que somos uno con ella.

En la tragedia el hombre sufre, pero al mismo tiempo goza y se provoca en él la vivencia estética que le produce contemplar su propia tragedia. Sucede entonces que el hombre es creador y espectador de sí mismo, es intérprete y crítico de su propia vida: la belleza triunfa y la filosofía se vuelve estética. No importa ya nada más que lo bello. Lo distinto y que se piensa diferente, muere para retornar a la unidad, al impulso original. El hombre es forma que se deforma, finitud infinita, vida que se apaga y que retorna siempre al mismo sitio donde se originó, para volver a contar lo vivido.

¿Qué ocurre en una vivencia estética? Por ejemplo, en la música todo es verdad y a la vez nada es verdad. La vivencia de la belleza es una paradoja, una contradicción placentera, un camino sin salida lógica que induce una ruptura en el ritmo cotidiano en el que transcurre nuestro vivir pragmático.

El sentimiento estético es real e ideal a la vez. Echa raíces en la realidad sensible, habla de hechos, personas y situaciones reales, pero al mismo tiempo, se afirma en él un mundo ilusorio. Al escuchar música, percibo la experiencia del artista que no es la mía, mas también soy yo el que la vive. Son mundos y universos paralelos, el del músico y el del espectador, la paradoja del mundo visto a través de los ojos del otro, de su mirar que hace al mío también; por un momento, me olvido de mi tiempo y entro al otro para regresar al cotidiano mío. Ahora imaginemos que yo soy el artista, el que crea música, y esta expresa mi sufrimiento, pero en la creación misma hay deleite y goce, y lo vivo y 
lo veo y se repite eternamente en mi vida. Por eso tenemos que contemplar la belleza de este ser y dejar a un lado los conceptos de bueno, malo, verdadero o falso para vivir y para contemplar.

La vida del hombre es bella expresión del uno primordial, que es la fuerza, la voluntad. El hombre trágico es una expresión individual de la voluntad. Pero este ser debe morir y deshacerse para regresar a la voluntad original.

Esa es la tragedia humana, la imposibilidad de permanecer como un yo, tener que ser vida que se destruye como separada para volverse a reunir con la unidad. El individuo quiere conservarse como forma diferenciada y esto genera sufrimiento, ya que se percibe como fragmentado, así como los amantes que se sintieron uno y que saben que tienen que separarse y esperar a regresar a la unidad.

José Manuel Orozco recomienda la lectura de su obra a aquellos que conozcan algo de Nietzsche y aún más a quien haya experimentado lo que dice el filósofo, con la finalidad de entender y sentir con más belleza y claridad la propia vida.

Además, en Nietzsche y la tragedia se establece una unidad entre dos conceptos fundamentales: la tragedia y la voluntad. Por la metafísica del artista se logra la unión con lo primordial, con el origen y la fuerza que es la voluntad. Zaratustra y la tragedia se unen, se dan la mano mostrando la fuerza y la coherencia del sistema nietzscheano. En esta unidad se ve la expresión desgarrada del uno vital, la forma individualizada hecha cuerpo que tiene que morir y deshacerse para retornar a la unidad primordial.

Así, la tragedia es un estado de experiencia en el que el yo se pierde a sí mismo, y esta pérdida se concibe como gozoso dolor. Es el momento embriagador de saberse uno con los demás; uno, pero también separado, esa contradicción constante de afirmar la vida pero también de negarla.

En su obra Nietzsche y la tragedia, José Manuel Orozco realiza la unión entre la metafísica de la vida y la voluntad de poder. Es un ensayo lleno de erudición, de análisis crítico y originalidad. Contempla en seis capítulos temas fundamentales para vincular dos conceptos básicos para Nietzsche: la tragedia y la voluntad, en el que ambas se unen como la unión de algo irreconciliable. A lo largo del texto, no solo entendemos la filosofía nietzscheana, sino que también aprendemos a percibir la vivencia personal y el análisis profundo del propio José Manuel Orozco. 